\title{
MODELO EMPÍRICO PARA A SELEÇÃO DE MÁQUINAS AGRÍCOLAS NA CULTURA DA SOJA CONSIDERANDO A PONTUALIDADE NA SEMEADURA
}

\author{
CRISTINA MONTEIRO VEIGA \\ Engenheira Agrônoma
}

Orientador : Prof. Dr. MARCOS MILAN

\begin{abstract}
Dissertação apresentada à Escola Superior de Agricultura "Luiz de Queiroz", Universidade de São Paulo, para obtenção do titulo de Mestre em Agronomia, Área de Concentração: Máquinas Agricolas
\end{abstract}

PIRACICABA

Estado de São Paulo - Brasil

Agosto -2000 


\author{
Veiga, Cristina Monteiro \\ Modelo empirico para a seleçāo de máquinas agricolas na cultura da soja \\ considerando a pontualidade na semeadura / Cristina Monteiro Veiga. - - Piracicaba, \\ 2000. \\ 75 p. : il. \\ Dissertaçāo (mestrado) - Escola Superior de Agricultura Luiz de Queiroz, 2000. \\ Bibliografia. \\ 1. Época da semeadura 2. Máquina agricola 3. Modelo matemático 4. Rendimento \\ agricola 5. Soja I. Título
}

CDD 633.34 
Tantas vezes pensamos ter chegado.

Tantas vezes é preciso ir além.

(Fernando Pessoa) 
Aos meus pais

Virgínia e João

e ao meu irmão

Márcio, 


\section{AGRADECIMENTOS}

A Deus por eu ter chegado até aqui.

Aos meus pais João e Virgínia pelo que me ensinaram, e ao meu irmão Márcio pelo apoio e amizade.

À ESALQ-USP, por receber-me e conceder-me a oportunidade para a realização de mais uma etapa acadêmica.

Ao Prof. Dr. Marcos Milan, pela fácil convivência, amizade, e orientação.

Ao Prof. Dr. José Armando Furlani Júnior e ao Prof. Dr. Luiz Geraldo Mialhe, pertencentes à banca examinadora, pelas criticas construtivas.

À FAPESP, pela concessão da bolsa e pelo financiamento do projeto.

Aos funcionários da Fazenda Areão, pela concessão e condução do experimento à campo, em especial ao engenheiro agrônomo Luiz Fernando Sanglade Marchiori e Sr. Valdinei Ribeiro Camargo.

À Usina Alta Mogiana pela concessão da visita ao sistema de produção da soja, em especial ao Departamento de Mecanização.

Ao instrutor de informática Emerson de Toledo, pelo auxilio no desenvolvimento do modelo computacional.

Aos funcionários do Departamento de Engenharia Rural, do setor de Máquinas Agrícolas, principalmente à Fernanda da Silva, $D^{a}$. Maria de Lourdes Franzini, Maria Helena Padilha e Luis Afonso Costa.

Aos colegas de curso José Barros, Sérgio Pereira, Alexandre Tachibana, Sérgio Bizuti, Ricardo Fernandes, João Araújo, Sérgio Carvalho, Ricardo Pinto, Fernando Pascolatti, Juan Bonnin e Edmilson Ruiz, pelo companheirismo.

Aos amigos ontem, hoje e sempre: Flávio Pereira, Wagner Campaner, Maurício Leon, Pedro Zambuzi, Goreth Nery, Raimundo Leite, Michele Costa, Márcia Simonete, Cláudia Teixeira, Aderbal Rocha, Cássio Cezare, em especial a Moizéis Nery e Moema Bueno, pela dedicação, carinho e apoio.

A todos aqueles que contribuiram de alguma forma. 


\section{SUMÁRIO}

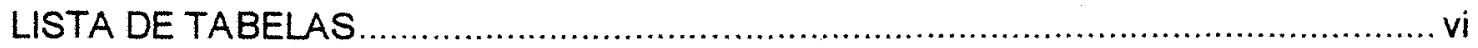

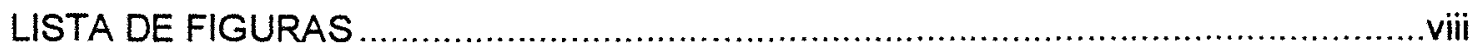

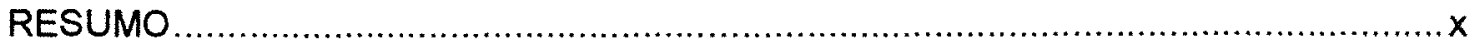

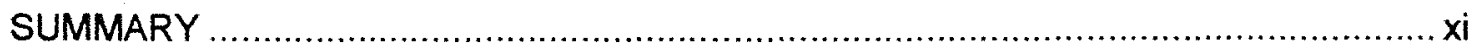

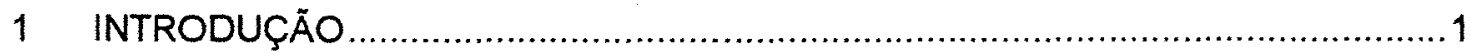

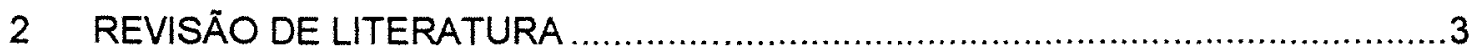

2.1 Modelos Associados à Seleção de Sistemas Mecanizados ................................ 3

2.2 Pontualidade e Seleção de Máquinas Agricolas ..............................................4

2.3 Pontualidade na Cultura da Soja............................................................. 6

2.3.1 Época do Preparo Periódico do Solo ,......................................................6

2.3.2 Época de Controle de Plantas Daninhas ..................................................... 7

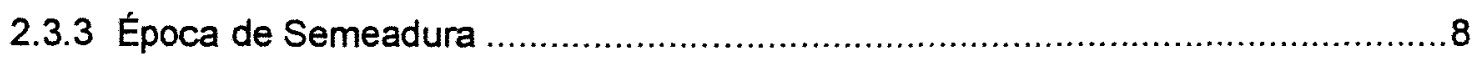

2.3.4 Época de Controle de Doenças e Pragas .............................................. 10

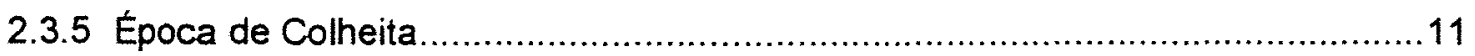

3 RENDIMENTO DA CULTURA DA SOJA EM FUNÇÃO DA

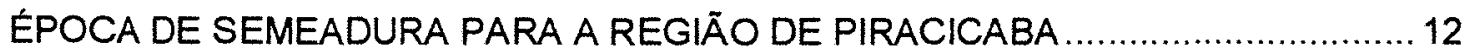

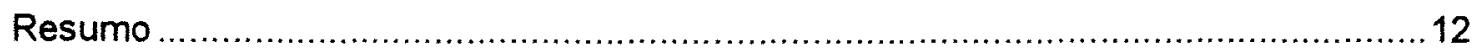

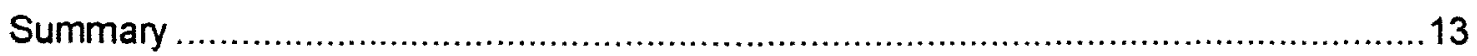

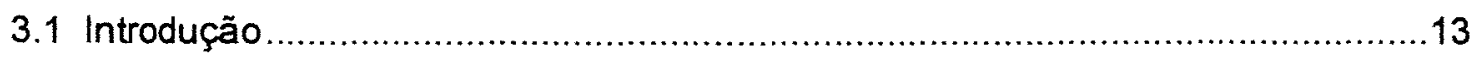

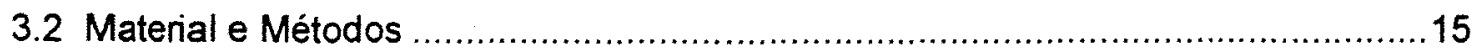

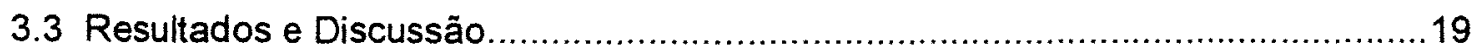

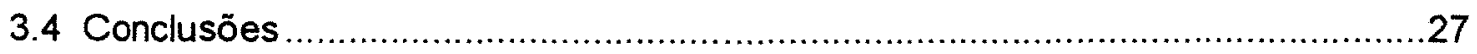

4 DESENVOLVIMENTO DE UM MODELO EMPIRICO PARA A SELEÇÃO DE MÁQUINAS AGRICOLAS NA CULTURA DA S̃OJA,

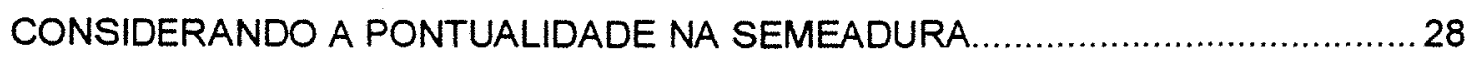

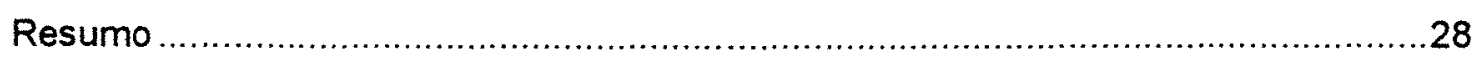

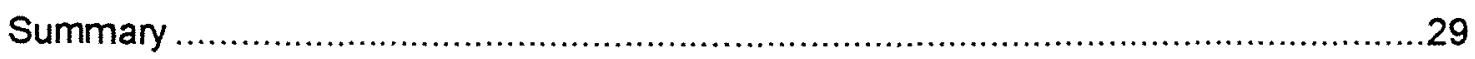




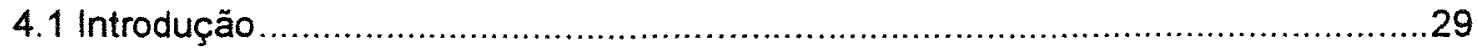

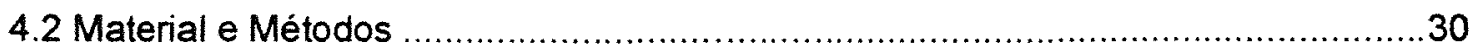

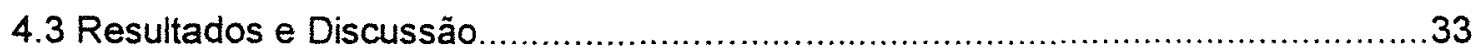

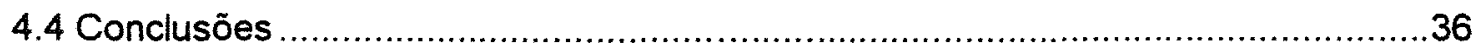

5 A PONTUALIDADE NA SEMEADURA DA SOJA E SEU EFEITO NO NÚMERO DE MÁQUINAS, RETORNO ECONÔMICO, CUSTO

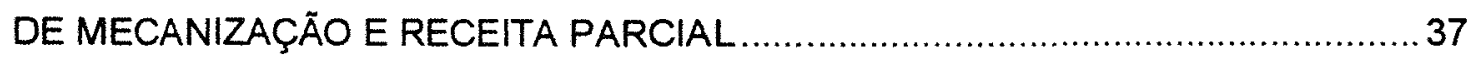

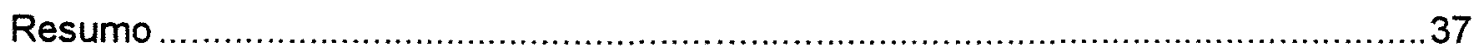

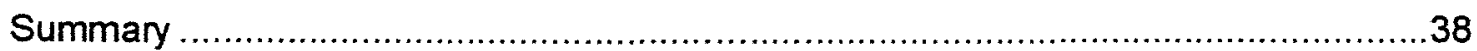

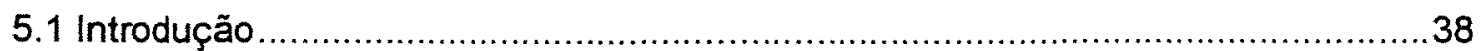

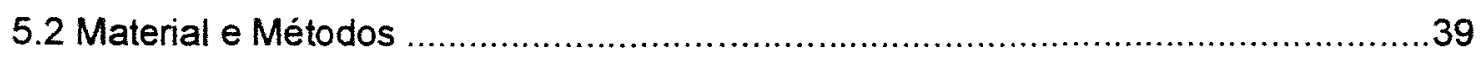

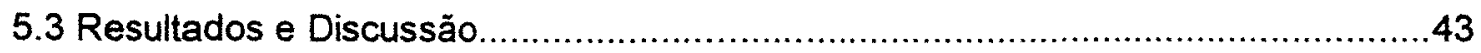

5.3.1 Número de Máquinas .....................................................................43

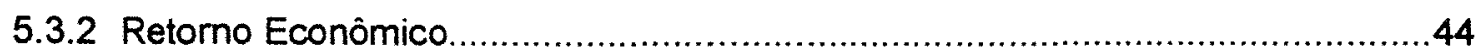

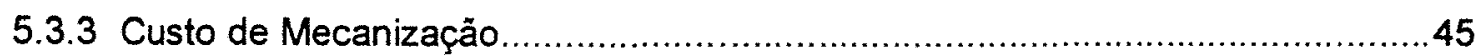

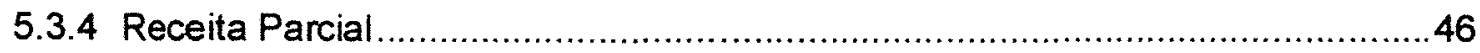

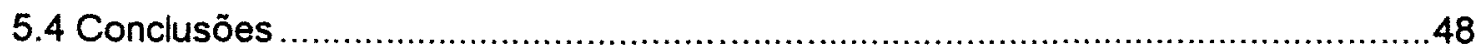

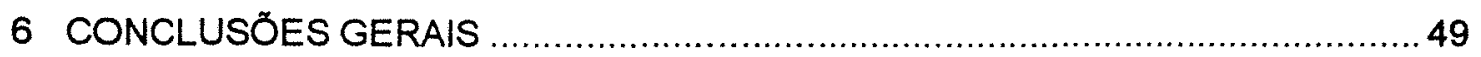

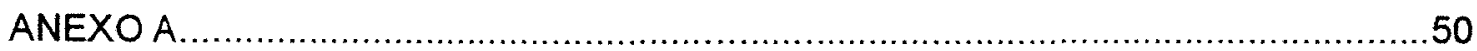

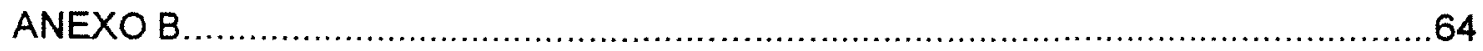

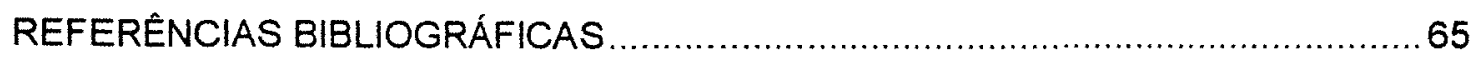




\section{LISTA DE TABELAS}

Página

Tabela 1.Resultados da análise química de solo da área experimental 15

Tabela 2. Épocas de semeadura do experimento.

Tabela 3. Data de ocorrência dos principais estádios fenológicos da soja, para o cultivar IAC 17, em dias após a emergência (DAE), e valores de atributos climáticos: radiação global, insolação, fotoperíodo, temperatura máxima, temperatura minima, nas datas de ocorrência do estádio fenológico considerado, precipitação pluvial total em cada subperíodo fenológico.

Tabela 4. Data de ocorrência dos principais estádios fenológicos da soja, para o cultivar IAC Foscarin 31, em dias após a emergência (DAE), e valores de atributos climáticos: radiação global, insolação, fotoperiodo, temperatura máxima, temperatura mínima, nas datas de ocorrência do estádio fenológico considerado, precipitação pluvial total em cada subperíodo fenológico.

Tabela 5. Análise de regressão polinomial com aplicação do teste F para cultivar de soja IAC Foscarin 31

Tabela 6. Análise de regressão polinomial com aplicação do teste F para cultivar de soja IAC 17.

Tabela 7. Rendimento esperado por semana de semeadura para a cultivar IAC 17 e das perdas na semeadura (\%).

Tabela 8. Planejamento das atividades agrícolas de acordo com a época de semeadura

Tabela 9. Prazo para cumprir as operações mecanizadas em relação a época de semeadura. 
Tabela 10. Máquinas selecionadas de acordo com a faixa de potência, onde: $L T=$ largura de trabalho; e $\mathrm{Pl}=$ preço inicial......

Tabela 11. Período de semeadura, para definir a pontualidade na operação mecanizada nos cenários estudados.

Tabela 12. Custo de mecanização (US\$ ha ${ }^{-1}$ ) e Receita Parcial (US\$ ha ${ }^{-1}$ ) para 12 semanas de semeadura. 48 


\section{LISTA DE FIGURAS}

\section{Página}

Figura 1. Estimativa do fotoperíodo para a região de Piracicaba.

Figura 2. Temperatura Máxima e Mínima Médias Mensais no período de 1917 a 2000, para a região de Piracicaba

Figura 3. Precipitação Pluvial Média Mensal ( $\mathrm{mm}$ ) no periodo de 1917 a 2000 , para a região de Piracicaba

Figura 4. Tendência de desempenho de rendimento $\left(\mathrm{kg} \mathrm{ha}^{-1}\right)$ em cada parcela, sob diferentes épocas, de semeadura para: (a) cultivar IAC 17; e (b) cultivar IAC Foscarin 31

Figura 5. Rendimento da cultivar IAC Foscarin $31 \mathrm{em}$ seis épocas de semeadura e a diferença, em percentagem, do rendimento comparado a melhor época.

Figura 6. Desempenho de rendimento médio $\left(\mathrm{kg} \mathrm{ha}^{-1}\right)$ para a cultivar IAC 17 em função de dias para a região de Piracicaba.

Figura 7. Fluxograma do modelo.

Figura 8. Validação do modelo em relação ao custo operacional(US\$ ha ${ }^{-1}$ ) em comparação com resultados obtidos em literatura e numa propriedade agrícola produtora de soja.

Figura 9. Validação do modelo em relação ao custo operacional nas operações mecanizadas (US\$ ha- ${ }^{-1}$, em comparação com resultados obtidos em literatura $e$ numa propriedade agricola produtora de soja.

Figura 10. Fluxograma básico do modelo. 41

Figura 11. Cenários desenvolvidos para aplicação do modelo, considerando a pontualidade.

Figura 12. Distribuição dos conjuntos mecanizados, de acordo como número de semanas de semeadura, para a área 
de 1500 ha em: a) uma semana de semeadura; b) doze semanas de semeadura.

Figura 13. Distribuição do retorno médio econômico em diferentes épocas de semeadura, destacando-se 0 menor e o maior valor obtido.

Figura 14. Custo de mecanização (US\$ ha ${ }^{-1}$ ) de acordo com o número de semanas de semeadura em três tamanhos de área: (a) 1500 ha; (b) 2500 ha; (c) 3500 ha.

Figura 15. Receita Parcial (US\$ ha ${ }^{-1}$ ) de acordo com o número de semanas de semeadura em três tamanhos de área: (a) 1500 ha; (b) 2500 ha; (c) 3500 ha. 


\section{MODELO EMPÍRICO PARA A SELEÇÃO DE MÁQUINAS AGRÍCOLAS NA CULTURA DA SOJA CONSIDERANDO A PONTUALIDADE NA SEMEADURA}

Autora: Cristina Monteiro Veiga

Orientador. Prof. Dr. Marcos Milan

\section{RESUMO}

O Brasil é o segundo produtor mundial de soja, com 31 milhões de toneladas. É uma das culturas que mais se utiliza a mecanização, podendo esse item pode representar $40 \%$ do custo total de produção. Estimativa referente ao custo indireto, ou pontualidade, ainda é desconhecida para o país. Pode ser mensurada pela perda no rendimento da cultura quando as operaçōes mecanizadas não são realizadas no prazo, causando redução na quantidade e qualidade de um produto agrícola. Como a época de semeadura determina o desenvolvimento da soja, devido a fotossensibilidade da cultura, há de se priorizar essa operação mecanizada. Nesse contexto, o objetivo do presente trabalho foi o de desenvolver um modeb capaz de avaliar os custos da mecanização sobre a influência da pontualidade na operação de semeadura sendo dividido em três etapas. A primeira referiu-se a determinação das equaçöes de rendimento da cultura de soja em função de diferentes épocas de semeadura. Na segunda foi o desenvolveu-se o algonitmo e o modelo computacional para o cálculo do custo da maquinaria, levando-se em consideração a pontualidade da semeadura, com base nas equações de rendimento. Na terceira aplicou-se o modelo para a simulação de cenários e a avaliação da pontualidade sobre a seleção de máquinas. Conclui-se 'que o modelo foi adequado para analisar o custo direto e indireto da mecanização. A equação de rendimento obtida foi satisfatória para a previsão de rendimento da cultura em diferentes épocas de semeadura. A seleção de máquinas agricolas pelo modeb apresentou rotina e resultados adequados quando comparados à literatura e a uma fazenda produtora de soja. 0 gerenciamento das máquinas agricolas que visa reduzir o número de conjuntos mecanizados para aumentar o número de horas de uso, traz a melhor receita na produção da soja, independente da época de semeadura. 
AN EMPIRICAL MODEL FOR CHOOSING FARM MACHINERY IN SOYBEAN CROP, CONSIDERING TIMELLINESS AT SOWING OPERATION

\author{
Author: Cristina Monteiro Veiga \\ Adviser: Prof Dr. Marcos Milan
}

\title{
SUMMARY
}

Brazil is the second world soybean producer with 31 millions of tons. It is one of crop in with mechanization is more utilized and the cost of this item can represent until $40 \%$ of the total production cost. The indirect cost is unknown for the country. This costs is measured throw the financial loss that is incurred because of inadequate scheduling of machinery operations, causing a reduction in crop yield and quality. As the planting date at soybean crop has the major impact, the sowed operation must have priority. In this context, this work was designed to develop one computational model able to evaluate the mechanization cost, include the timeliness. It was divided in three parts. The first one was to determinate the soybean yield empirical model in different planting date. The second was to develop an algorithm and a computational model to schedule farm machinery and to calculate the mechanization cost, considering the timeliness by the soybean yield equation. And the last part was to use the computational model to study the timeliness effects at machinery selection. The computational model was adequate to evaluate the direct and indirect costs of machinery operations. The soybean equation was adequate to preview the yield in different conditions of planting date. The routine was verified and the validation was made comparing the programs results with literature value showed that the computational model can be used for another situations. And the machinery management that reduces the number of agricultural machinery and increase the hourly operation machinery utilization results the best profit, instead of sowed soybean out of the best yield planting date. 


\section{INTRODUÇÃO}

A cultura da soja (Glycine max (L) Merril) é originária do continente asiático onde referências quanto a sua utilização datam de 2.838 a.C., sendo trazida para o Ocidente ao final do século XV. No Brasil a cultura foi introduzida no inicio do século e as primeiras exportações realizadas em 1949. Nas décadas de $60 / 70$ a soja teve um grande impulso na região Sul do país, expandindo-se para o Centro-Oeste entre 1970/80, e atualmente atingindo a região Norte (Câmara, 1998b).

O Brasil é atualmente o segundo maior produtor mundial da soja, superado apenas pelos Estados Unidos. Na safra $1998 / 1999$ produziu 31 milhões de toneladas na safra 1998/99 em cerca de 13 milhões de hectares de área colhida, representando assim um rendimento médio de $2400 \mathrm{~kg} \mathrm{ha}^{-1}$ (Empresa Brasileira de Pesquisa Agropecuária - EMBRAPA, 1998). O maior produtor brasileiro é o Estado do Paraná, com 2,7 milhões hectares plantados e rendimento de $2550 \mathrm{~kg} \mathrm{ha}^{-1}$. O Estado de São Paulo situa-se no lugar do $6^{\circ}$ maior produtor, cultivando cerca de 514 mil de hectares. Dos 645 municipios paulistas, 185 cultivam soja sendo as duas maiores regiōes produtoras o Vale do Paranapanema com 200 mil de hectares e Alta Mogiana com 300 mil de hectares. O rendimento médio do Estado oscila em torno de $2400 \mathrm{~kg} . \mathrm{ha}^{-1}$, embora produtores mais tecnificados atingem a $3000 \mathrm{~kg} \mathrm{ha}^{-1}$ (Diehl, 1999).

\footnotetext{
- Rendimento, segundo Dourado Neto (1999), pode ser expresso por $R=(f-P)$, onde $R=$ rendimento da cultura (kg ha $\left.{ }^{-1}\right)$; $f=$ fator adimensional de perda e $P=$ produtividade $\left(\mathrm{kg} \mathrm{ha}^{-1}\right)$, conseqüente do potencial genético da planta sob uma condiçảo edafoclimática representativa. Na prática, procura-se minimizar o fator de perda, já que a produtividade nảo é observàvet. Segundo Mialhe, rendimento é a relaçäo entre duas capacidades operacionais, variáveis relacionadas à Mecanizaçáo Agricola. Para Ferreira (1999), rendimento e produtividade sảo sinônimos.
} 
A cultura é totalmente mecanizada (da semeadura a colheita), o que facilitou a rápida expansão durante a década de 70 . Hoje a mecanização representa uma das principais causas dos custos de produção da cultura. Os custos diretos referentes ao uso de máquinas agricolas podem variar de acordo com o rendimento obtido, segundo FNP (1998); em geral atinge $40 \%$ dos custos de produção no plantio convencional e $30 \%$ no plantio direto. Estimativa referente aos custos indiretos, definidos como aqueles causados principalmente pelas perdas na produção devido a não realização das operações agrícolas nos prazos determinados, ainda é desconhecida para as condições do país. Esses custos podem advir de uma seleção inadequada do sistema mecanizado

A quantidade de marcas e tipos de máquinas disponíveis no mercado e os custos indiretos associados à pontualidade das operações, torna a seleção de sistemas mecanizados uma atividade complexa. A modelagem desses sistemas, como um recurso auxiliar para a tomada de decisão, permite com que as variáveis envolvidas sejam estudadas e avaliadas quanto a importância na composição dos custos de produção.

Desenvolveu-se o presente trabalho em vista a importância da cultura, não só para o Estado de São Paulo como também para o pais, bem como as dificuldades inerentes ao dimensionamento das máquinas agricolas. O objetivo foi de elaborar e aplicar um modelo empirico para a seleção e cálculo dos custos de sistemas mecanizados para a cultura da soja, visando o rendimento em função das diferentes épocas de semeadura, caracterizando a pontualidade, na obtenção da receita gerada pela cultura da soja.

Para atender ao objetivo acima citado, o trabalho foi dividido em três partes distintas. A primeira refere-se ao desenvolvimento de um modelo empirico para determinar o rendimento da cultura da soja em função da época de semeadura. $A$ segunda refere-se ao desenvolvimento de um modelo computacional para o cálculo dos custos do sistema mecanizado de acordo com a época de semeadura. A terceira é a aplicação do modelo para a avaliação de cenários, considerando a pontualidade. 


\section{REVISÃO DE LITERATURA}

\subsection{Modelos Associados à Seleção de Sistemas Mecanizados}

A maioria dos modelos desenvolvidos para selecionar as máquinas procura calcular a faixa de potência ideal para as operações de campo devido à sua relação com a largura de trabalho de implementos, influenciando diretamente no preço de aquisição dos equipamentos, base dos custos da mecanização. As soluções dadas pela modelagem tornam a atividade do cálculo dos custos mais simples pois podem armazenar dados relevantes de todas as máquinas além de observar o efeito de diferentes faixas de potência para diferentes tamanhos de área (Hunt, 1974).

Chancellor (1969) realizou a seleção de tratores através da faixa de potência e número de conjuntos mecanizados em diferentes tamanhos de área sob o ponto de vista econômico. Concluiu que a utilização de apenas um conjunto mecanizado em áreas pequenas com uso de tratores de potência em torno de $100 \mathrm{c.v}$. diminuem os custos horários.

Quando a potência é determinada, o próximo passo é adequar os implementos que serão acoplados ao trator (Witney e Eradat, 1982). White (1986) desenvolveu em modelo cujos parâmetros utilizados foram: eficiência na barra de tração do trator, resistência do solo, eficiência da capacidade operacional das máquinas e área de cultivo adicionada à probabilidade de quebras das máquinas. Mas, outros parâmetros podem ser associados às operações tais como tipo e condições de teor de água no solo, velocidade e profundidade de trabalho. Com esses parâmetros a largura de trabalho dos implementos pode ser determinada na forma de ábacos (Zoz, 1974; Stolf, 1986) ou no cálculo da força de tração exigida por haste ou área de solo mobilizada, 
otimizando a potência disponivel na barra de tração ou tomada de potência (Harrigan e Rotz, 1994; Glancey et al., 1996).

Levantada as características que os conjuntos mecanizados apresentam, é preciso definir de que modo os mesmos atuarão no campo. Milan (1992) desenvolveu modelo específico para a cultura de cana-de-açúcar que identificava as variáveis críticas envolvendo custos no sistema de produção. A seleção o conjunto mecanizado (trator-implemento) foi feita com base na seqüência de operações a serem realizadas por talhão. Conclui o autor que uniformizando-se a frota de tratores para uma faixa de alta potência influi na diminuição no número de conjuntos, aumentando as horas de uso das máquinas e conseqüentemente na diminuição do custo horário. Outra forma de modelagem é a programação linear, muito utilizada quando surgem os fatores de restrição como investimento, que procura otimizar o número de conjuntos, tempo disponivel ou mão de obra de acordo com o orçamento (Philips e Callagan, 1974; Banchi, 1981; Stonner et al., 1992; Jannot e Carol, 1996).

Como o planejamento das atividades agrícolas se torna cada vez mais complexo a medida que muitos processos dinâmicos da agricultura são considerados (Duffy e Taylor, 1993), Parmar et al. (1996) utilizaram algoritmos genéticos para seleção da máquinas agrícolas, para atingir a otimização plena a longo prazo. No programa, os bits se comportam como cromossomos na seleção natural. Sendo assim, a frota de conjuntos mecanizados se adapta a diferentes condições até atingir o equilíbrio, obtendo-se a frota minima durante um longo periodo para a cultura.

\subsection{Pontualidade e Seleção de Máquinas Agrícolas}

O conhecimento da interação entre os efeitos da data de semeadura e colheita sobre o rendimento pode otimizar as combinações das operações, levando a minimização das perdas por pontualidade (Chancellor e Cervinka, 1974).

De acordo com Balastreire (1987), a pontualidade em máquinas agricolas é a capacidade de efetuar as operações na época em que a qualidade e a quantidade de um produto são otimizadas. Dependendo da cultura, algumas operações têm de ser prioritárias; caso contrário, o rendimento pode chegar a niveis muito inferiores 
daqueles esperados. O levantamento destas perdas por prazo de operação é extremamente útil para selecionar o número e tamanho do maquinário agricola necessário, sem que haja o superdimensionamento de potência ou sobrecarga de trabalho para um trator agricola. Portanto a pontualidade deve ser aceita como parte da eficiência na seleção. Quando o maquinário em questão não está bem dimensionado, é comum que as operações não sejam realizadas a tempo, ocorrendo as perdas. A pontualidade é mensurada como custo indireto de maquinário, sendo associada principalmente à implantação, pulverização e colheita das culturas em épocas inadequadas, ocasionando maiores perdas no rendimento (Witney, 1988).

Em alguns modelos desenvolvidos para otimizar a seleção de máquinas agrícolas na cultura da soja e milho, a pontualidade foi determinada pelas perdas devido ao atraso na época de semeadura (Burrows e Siemens, 1974, Audsley et al., 1978; Parsons et al., 1981; Chen e Mc Clendon, 1984; Mc Clendon et al., 1987). Ademouson (1991) minimizou a ociosidade das máquinas ao longo do ano, objetivando a diminuição do número de tratores e mão de obra, tendo a pontualidade como fator de restriçäo. Tsai et al. (1987) levaram em consideração as diferentes fases de desenvolvimento da planta para a simulação e otimização de técnicas de rotação de cultura no modelo criado para irrigação. Oskan e Holmes (1990), no modelo DRAINMOD, adicionaram ainda o excesso e déficit hídrico como forma de cálculo da pontualidade.

Segundo Hunt (1974), a mesma cultura pode apresentar resultados de desempenho de rendimento diferentes dependendo tanto região como da variedade utilizada. Após a quantificação das perdas é possivel determinar o fator de perda de pontualidade associado às operações de máquinas agrícolas. No modelo de Edwards e Boejlhe (1980), foram calculadas as perdas de produção devido a diferentes épocas de semeadura de milho e soja. Através da quantificação das perdas e análise do preço de mercado das culturas determinou-se o custo de pontualidade.

Lal et al. (1990) desenvolveram um modelo de seleção de máquinas agrícolas denominado FARMASYS, onde a pontualidade foi mensurada pela perda por dia de atraso nas operações mecanizadas. A validação do modelo (Lal et al., 1991) indicou que a metodologia adotada pelos autores tornou-se uma altemativa prática de desenvolvimento de modelos para atender à seleção adequada de máquinas. A limitação do programa, entretanto, foi a impossibilidade de utilizá-lo em área menores e 
sistemas de produção agropecuários, para tomá-lo mais versátil e abrangente (Lal et al., 1992).

O modelo PNUTMM (Parmar et al., 1994) foi criado para o gerenciamento de máquinas agricolas utilizadas na cultura do amendoim. Nele foi incorporado o modelo PNUTGRO $V$ ' 1.02 que simula o teor de água na semente, maturação fisiológica e data ótima de colheita, para a determinação do custo de pontualidade. Segundo Hoogenboom et al. (1992), o modelo criado para amendoim (PNUTGRO) tem a mesma estrutura matemática e arquivos de dados que para cultura da soja (SOYGRO). Estes modelos simulam as diferentes fases de crescimento da planta, déficit hídrico e produção em função de diferentes tipos de solo, clima e manejo da cultura e podem ser associados à modelagem destinada ao planejamento das atividades agricolas.

\subsection{Pontualidade na Cultura da Soja}

\subsection{1 Época do Preparo Periódico do Solo}

O preparo periódico pode ser realizado tão logo que as condições do solo sejam propicias ao uso das máquinas. Como geralmente são operações que exigem maior potência dos tratores, alguns agricultores iniciam bem antes da época recomendada para reduzir o número de máquinas utilizadas nessas operações. Tem como finalidade oferecer condições ideais para o desenvolvimento das plantas. $E$ realizado onde não existe a possibilidade de técnicas de utilização da semeadura direta (Balastreire, 1987). O ideal é que o preparo do solo ocorra logo após o início das primeiras chuvas, normalmente em setembro. Mas ainda existe um periodo até o início da semeadura em que o solo fica exposto pois é necessária a espera de chuvas regulares para a emergência das plântulas. Enquanto isso propicia o crescimento de plantas daninhas que compromete o desempenho das semeadoras e competem com a cultura por luz, água e nutrientes (Mello, 1988; Souza et al., 1996).

Para os autores Bumside et al. (1980) e Elmore (1990), o rendimento não é afetado por diferentes tipos de preparo do solo. Entretanto, Prasad (1996) afirma que a 
qualidade de semeadura e rendimento da soja no plantio direto foram melhores do que aquela obtida usando métodos convencionais.

\subsection{2 Época de Controle de Plantas Daninhas}

As plantas daninhas concorrem com a cultura da soja pelos fatores ambientais, causando significativas perdas que variam de $37 \%$ a $99,9 \%$ do rendimento; esse último valor ocorrendo quando não existe controle em nenhum momento (Blanco et al. , 1973; Rezende et al., 1985; Fleck e Candemil, 1995). Além disso, as plantas daninhas podem servir de hospedeiras de pragas, nematóides e doenças (Ferraz, 1985). Quando a competição é evitada, da germinação da cultura até 45 a 50 dias depois, as infestações posteriores não afetam o rendimento (Blanco et al., 1973).

Quantificar precisamente os prejuizos provocados pelas plantas daninhas não é suficiente para se determinar a necessidade ou não de adotar medidas de controle. Nem sempre o ganho de rendimento justifica a eliminação total de espécies que se desenvolvem junto a soja. Desta forma, a relação custo/beneficio é inviável pois o custo suplantaria o ganho econômico obtido no rendimento final (Fleck e Candemil, 1995). Fleck (1996) constatou que a redução causada ao rendimento dos grãos pela interferência do papuã (Brachiaria plantaginea) é maior em condiçōes de alto rendimento e nessa situação, obtém-se maior ganho econômico decorrente do seu controle.

Uma das críticas apontadas ao plantio direto é que exige maior consumo de herbicidas do que o convencional, o que torna o sistema mais oneroso. Esse maior consumo advém substituição do preparo mecânico do solo pela operação de manejo químico das plantas infestastes e os cultivos por herbicidas (Marochi, 1996). Os recursos utilizados para reduzir os custos com a pulverização dos herbicidas, são aumentar o prazo de aplicação no campo, para diminuir o número de conjuntos, ou diminuir as doses de herbicida (Fleck et al., 1995). Com isso, Fleck et al.(1997) estudou a associação de épocas de aplicação com redução na dose de herbicida, concluindo que é viável a aplicação de meia-dose de herbicida efetuada até 3 a 4 semanas após a emergência para obter um bom nível de controle, evitando adotar esse método após 5 semanas de emergência das plântulas. A espera por chuva 
também pode adiar a aplicação, o que pode causar maiores perdas no rendimento da cultura por afetar a eficiência de alguns herbicidas (Marochi, 1996).

Existem ainda modelos especificos para o controle de plantas daninhas, que trazem a simulação do rendimento da cultura sob diversas maneiras de cultivo (mecânico, biológico ou químico). Esses modelos analisam a população da plantas invasoras e as vantagens de se aplicar ou não herbicidas para minimizar as perdas no rendimento (Schweizer et al., 1992; Swinton e King, 1994; Dileman, 1995, Lindiquist et al., 1995).

\subsection{3 Época de Semeadura}

A adaptação de uma espécie a determinada região está condicionada a fatores térmicos e hídricos, enquanto as cultivares têm sua adaptação relacionada ao fotoperiodo (EMBRAPA, 1997b).

A soja é considerada uma cultura termo e fotossensivel, sendo assim, quando suas exigências climáticas não são atendidas, a planta está sujeita a alterações fisiológicas e morfológicas afetando o rendimento e arquitetura (EMBRAPA, 1997b). A maioria das cultivares respondem ao fotoperiodo como plantas de dias curtos e florescem quando a duração dos dias é menor que o valor determinado $(13,3$ a 13,5 horas de fotoperiodo), ou seja, atingem o fotoperíodo critico, apresentando restrições no que se refere à adaptação a uma faixa estreita de latitude (Marcos Filho e Novembre, 1990; Câmara, 1998b). Estas características são controladas geneticamente, (Cober et al., 1996) havendo interações entre genótipo e a localidade de semeadura (Outtara e Weaver, 1995).

Nos Estados Unidos, a classificação das cultivares para época de semeadura é dado através de uma escala de 0 a $X$, onde a diferença de cada grupo varia de 10 a 18 dias. As cultivares do grupo $I X$ e $X$ são desenvolvidos para regiões tropicais de baixa latitude, no caso Norte e Nordeste do Brasil (Câmara, 1992; EMBRAPA, 1990), país em que as cultivares são classificadas como precoces, médios e tardios (EMBRAPA, 1997b). 
Num estudo realizado por Queiroz (1975), foram utilizadas cultivares representantes de diferentes grupos de classificação (V, VI, VII e VIII) em duas épocas (ideal e tardia). O rendimento médio das cultivares não apresentou diferenças significativas, apoiando a prática da semeadura de cultivares de diversos grupos de maturação numa mesma propriedade.

Weiss et al. (1950) e Osler e Carter (1954) concluiram que uma cultivar tardia, em uma dada latitude, mostrou menor resposta na data de maturação que uma precoce no que se refere as semeaduras tardias. Sweeney et al. (1995) enfatizam o uso de cultivares precoces. De acordo com os autores, estas cultivares se adaptam mais facilmente à uma determinada região do que as tardias.

Grimm et al. (1996) notaram uma nítida diferença de rendimento entre cultivares em relação ao fotoperíodo, mas rendimento similar quanto ao estudo direcionado à temperatura. E salientam a caracterização dos eventos fenológicos, como o florescimento, pois é o fator que têm maior importância para a criação de modelos que incluam crescimento e o rendimento de soja.

Em zonas temperadas, a resposta da soja ao fotoperiodo sincroniza o crescimento e reprodução de acordo com as estações. Nos trópicos, aonde a soja pode se desenvolver todo o ano, a insensibilidade ao fotoperiodo pode permitir ampla adaptação a diferentes latitudes e estações (Gazzoni, 1995).

Parker et al. (1981) estudaram o efeito da diferentes datas de semeadura e espaçamento de plantas sobre o rendimento e outras caracteristicas agronômicas. Concluíram que a semeadura cedo ou tardia normalmente apresentam baixo rendimento e que os cultivares precoces foram mais afetados pelas diferentes datas de semeadura do que os cultivares tardios.

Queiroz (1988) determinou o rendimento de dezesseis cultivares de soja, semeadas em cinco diferentes épocas no norte do Paraná; os resultados demonstram que o mês de novembro é o que melhor retorno traz ao rendimento.

Para todo o país, a recomendação da EMBRAPA (1997b) é que a semeadura se realize entre 20 de outubro a 10 de dezembro, sendo novembro o mês ideal. $A$ entressafra é recomendada para regiões onde não haja ocorrência de baixas temperaturas e exista disponibilidade de umidade no solo (natural ou irrigação). A época de semeadura neste caso passa a ser de 20 de abril a 20 de maio, evitando-se 
o uso de cultivares de ciclo tardio em semeadura a partir de 15 de maio, para que a colheita não coincida com o período chuvoso.

De acordo com Câmara (1998a) a época de semeadura normal proporciona maior rendimento de grãos do que tardias, independente da combinação de cultivares e densidades de plantas.

\subsection{4 Época de Controle de Doenças e Pragas}

Nakano et al. (1981) advertem que o manejo no controle de pragas para a soja deve abranger todos os meios disponiveis, incluindo a época de semeadura. Enfoque é dado a infestação de percevejo, pois o mesmo costuma colonizar as plantas em diversos estágios de desenvolvimento, em especial na fase de formação ao amadurecimento das vagens. Podem ser observadas populaçöes desses insetos desde o periodo vegetativo, com crescimento exponencial e acelerado no final do ciclo da cultura, principalmente em cultivares de ciclo médio ou tardio (Gazzoni, 1998).

Câmara et al. (1995) analisando isoladamente fungos fitopatogênicos encontrados nas sementes dos cultivares estudados, concluiram que existe correlação entre os cultivares e tipos de fungos encontrados nas plantas, de acordo com a época de semeadura.

O cultivo tardio de soja é recomendado para regiões propícias a chuvas durante a maturação, com finalidade de produção de sementes. Dhingra et al. (1979) observaram correlação positiva entre porcentagem de sementes infectadas com o fungo Phomosis sojae e a porcentagem de plântulas necróticas. A recomendação é realizar a semeadura tardia de cultivares de maturação precoce, evitando-se também perdas por ataque de percevejos ou veranicos (EMBRAPA, 1997b).

Browde et al. (1994) analisaram o efeito de época sobre o de ataque de nematóides do cisto, plantas daninhas e insetos desfolhadores. Os componentes de desempenho mais afetados foram número de vagens por planta e peso de grãos por vagem causada pela redução de produção de fotoassimilados. 


\subsection{5 Época de Colheita}

A colheita de soja deve ser iniciada tão logo a planta atinja o ponto de maturação, para que não haja perdas na qualidade do produto. Uma vez atingido esse ponto, a tendência é a deterioração dos grãos e deiscência das vagens, que se intensificam a medida que o tempo passa (EMBRAPA, 1997b). A semeadura na época adequada e o espaçamento das plantas facilitam a colheita mecanizada devido a altura da inserção de vagens e o índice de acamamento.

A colheita tardia aumenta a porcentagem de sementes quebradas na trilha devido a perda do teor de água além de aumentar a incidência de fungos, o que diminuiu a germinação e o vigor de sementes (Sediyma, 1972; Santos et al., 1996). 


\section{RENDIMENTO DA CULTURA DA SOJA EM FUNÇÃO DA ÉPOCA DE SEMEADURA PARA A REGIÃO DE PIRACICABA}

\section{RESUMO}

A cultura da soja, devido a sua importância econômica para o Brasil, remetem a estudos voltados principalmente à redução de seu custo de produção. A modelagem é uma das técnicas mais recentes de se prever o desempenho de rendimento das culturas a diversos fatores ambientais sob diferentes regiōes e situações, visando otimizar o seu manejo. $O$ objetivo desse trabalho foi encontrar um modelo que expressasse o rendimento da cultura da soja considerando diferentes épocas de semeadura. A área experimental localizou-se no municipio de Piracicaba, SP, durante o ano agrícola 1998/1999 em sete épocas de semeadura com o cultivar IAC-17 (17/09/98, 2/10/98, 19/10/98, 03/11/98, $17 / 11 / 98,2 / 12 / 98$ e 17/12/98) e seis épocas de semeadura com cultivar IAC-Foscarin 31 (2/10/98, 19/10/98, 03/11/98, 17/11/98, 2/12/98 e 17/12/98). As parcelas foram compostas por cinco linhas com 5,0 m de comprimento, no espaçamento de 0,50 m entre linhas, com 20 plantas $\mathrm{m}^{-1}$, e população final de $4 \times 10^{5}$ plantas ha ${ }^{-1}$, sob o delineamento em blocos completos ao acaso com três repetições cada época. Houve efeito de épocas sobre o rendimento da cultivar $I A C$ 17, cujo modelo matemático foi: $Y=-0,613 X^{2}+59,716 X+1763,6$ $\left(R^{2}=0,80\right)$, em que $Y$ é o rendimento esperado da cultivar $I A C 17\left(\mathrm{~kg} \mathrm{ha}^{-1}\right)$ e $X$ o número de dias após a primeira semeadura. Conclui-se que é possivel estimar o rendimento da cultivar IAC-17 através de modelagem. Para o cultivar IAC Foscarin 31 foi determinada a média de rendimento nas seis épocas estudadas. A metodologia se tomou adequada para deteminar o modelo empírico matemático de rendimento de soja para diferentes cultivares e regiões, com a possibilidade de inserir a equação em modelos computacionais de planejamento agricola e determinar a pontualidade na semeadura. 


\section{SUMMARY}

\section{SOYBEAN YIELD IN CONSEQUENCE OF DIFFERENT PLANTING DATE AT PIRACICABA, SP, BRAZIL}

Due soybean importance at Brazil, a lot of studies have been made to provide the least production costs. Modeling is one technical way to preview the how the yield crop development will answers to many different ambient and regions conditions. The aim of this work was to determinate the soybean yield empirical model in different planting date to obtain one equation that can be used in agricultural management models. The experimental area was localized at Piracicaba, SP, Brazil, during $1998 / 1999$ in seven planting dates $(17 / 09 / 98,2 / 10 / 98,19 / 10 / 98,03 / 11 / 98,17 / 11 / 98$, $2 / 12 / 98$ e $17 / 12 / 98)$ to IAC 17 cultivar and six planting dates $(2 / 10 / 98,19 / 10 / 98$, 03/11/98, 17/11/98, 2/12/98 e 17/12/98) to IAC Foscarin 31 cultivar. The experimental plots, with five rows of $0,5 \mathrm{~m}$ width and 5,0 long and 20 plants $\mathrm{m}^{-1}$ with $4 \times 10^{5}$ final population, were randomized in blocks with three replications each planting date. There was planting data effect at IAC 17 cultivar yield, whose mathematical model was $Y=$ $0,613 X^{2}+59,716 X+1763,6\left(R^{2}=0,80\right)$, where $Y$ is the $I A C 17$ cultivar yield $\left(\mathrm{kg} \mathrm{ha}^{-1}\right)$ and $X$ is the numbers of days after first planting date. The conclusion was that it is possible estimate the IAC 17 cultivar yield throw the model and for estimate IAC Foscarin 31 yield can be used the average yield at six planting date. The methodology was adequate to establish the mathematical model of soybean yield to different cultivars and regions with the possibility to insert the equation at computational models for agricultural management.

\subsection{INTRODUÇÃo}

A soja (Glycine Max (L.) Merrill) constitui hoje num dos principais produtos agrícolas comercializados no mundo devido ao seu valor nutritivo que atende a alimentação humana e animal. O Brasil é segundo maior produtor de soja, com produção estimada em 31 milhões de toneladas para o ano agricola 1998/1999, em 
cerca de 13 milhões de hectares (EMBRAPA, 1998). A crescente necessidade por óleos e proteinas derivados da soja faz com que aumente a necessidade de estudos dirigidos à cultura e que tragam soluções a diversos problemas que atingem à sua produção (Câmara, 1998b).

Dentro do Estado de São Paulo, $6^{\circ}$ maior produtor nacional, a área ocupada pela soja atinge cerca de 514 mil hectares, com rendimento médio de $2350 \mathrm{~kg} \mathrm{ha}^{-1}$ (Diehl, 1999). A cultura é utilizada principalmente em rotação com a cana-de-açúcar, na reforma de canaviais do Estado (Mascarenhas et al., 1994). Ultimamente, devido à proibição de queima e restrições associadas à colheita mecanizada de cana, como a região de Piracicaba, indicam um aumento na área exclusiva para a semeadura da soja para todo o Estado (Diehl, 1999).

Modelagem de projetos econômicos, como as simulações de rentabilidade, em função da variação de preços e custos de produção já são utilizadas, em que as planilhas de custo representam sua forma mais simples (Bernardes, 1999). Com o aumento do uso da informática do setor agricola (Francisco e Martin, 1999), a utilização de modelos mais sofisticados, permitem prever com segurança a resposta da cultura a diversos fatores ambientais, estimando o desempenho em diferentes áreas e situações (Farias, 1999). Morrison (1991) descreve a modelagem como um método de expressar o conhecimento de forma quantitativa, por meio de equações preditivas, de maneira que a combinação entre elas seja integrada. Quando o modelo matemático que descreve o fenômeno é obtido pela quantificação estatística, através de análise de regressão, os modelos são definidos como empíricos, pois o mesmo não tem a preocupação em formular teorias de conhecimento sobre a relação causa-efeito (Rengel, 1993).

Muitos modelos têm como objetivo prever o rendimento da cultura da soja segundo as condições edafoclimáticas da região (Camargo et al., 1986; Hoogenboom et al., 1992). O modelo mais simples de estimativa é através da época de semeadura. Como característica intrínseca, a soja é considerada uma cultura termo e fotossensivel, sendo assim, quando suas exigências climáticas não são atendidas, a planta está sujeita a alterações fisiológicas e morfológicas afetando o rendimento e arquitetura (EMBRAPA, 1997b). A cultura é classificada como planta de dias curtos e floresce quando a duração dos dias é menor que o valor determinado, conhecido como fotoperiodo crítico (Câmara, 1998b). $O$ periodo mais indicado para a semeadura no 
Estado de São Paulo deve estar compreendido entre 16 de outubro a 30 de novembro (Marcos Filho e Novembre, 1990; Marchiori, 1998).

Devido a restrição referente a época de semeadura, existem os reflexos negativos no custo de produção relacionados, por exemplo, a maior quantidade de conjuntos mecanizados para a operação. Preestabelecer o rendimento em função da época é de fundamental importância para a tomada de decisão. Com isso, objetivo desse trabalho foi de quantificar a influência da época de semeadura no rendimento de cultivares da cultura da soja, visando desenvolver um modelo matemático empírico que possa ser utilizado no planejamento agricola para a determinação da pontualidade em máquinas agrícolas.

\subsection{MATERIAL E MÉTODOS}

A área experimental localizou-se no município de Piracicaba, SP, localizada a $22^{\circ} 41^{\prime} 30^{\prime \prime}$ de latitude Sul, $47^{\circ} 38^{\prime} 30^{\prime \prime}$ de longitude Oeste e $546 \mathrm{~m}$ de altitude. O solo da instalação do experimento é classificado como solo Podzólico Vermelho Escuro, textura argilosa, com caracteristicas quimicas apresentadas na Tabela 1., determinadas no Laboratório de Solo do Departamento de Ciência do Solo da ESALQ/USP. Para estimar a potencialidade da região para a instalação da cultura da soja foram levantados os parâmetros metereológico, em termos médios, de fotoperiodo (Figura 1), temperaturas máxima e mínima (Figura 2) e precipitação pluvial (Figura .3) que caracterizam o local.

Tabela 1.Resultados da análise química de solo da área experimental

\begin{tabular}{|c|c|c|c|c|c|c|c|c|c|c|c|}
\hline Prof. ${ }^{1}$ & $\mathrm{PH}$ & & $P$ & $\mathrm{~K}$ & $\mathrm{Ca}$ & $\mathrm{Mg}$ & $\overline{A l}$ & $\mathrm{H}+\mathrm{Al}$ & $\overline{S B}$ & $\mathrm{~T}$ & \\
\hline (am) & $\left(\mathrm{CaCl}_{2}\right)$ & $\left(\mathrm{g} \cdot \mathrm{dm} \mathrm{m}^{-3}\right)$ & $\left(\mathrm{mg}^{2} \cdot \mathrm{dm}^{-3}\right)$ & & & & mol.dr & & & & (\%) \\
\hline $0-20$ & 4,8 & 25 & 6,0 & 2,8 & 34 & 16 & 2,0 & 68 & 52,8 & 104,5 & 43,71 \\
\hline
\end{tabular}

${ }^{1}$ Profundidade de amostragem do solo. 


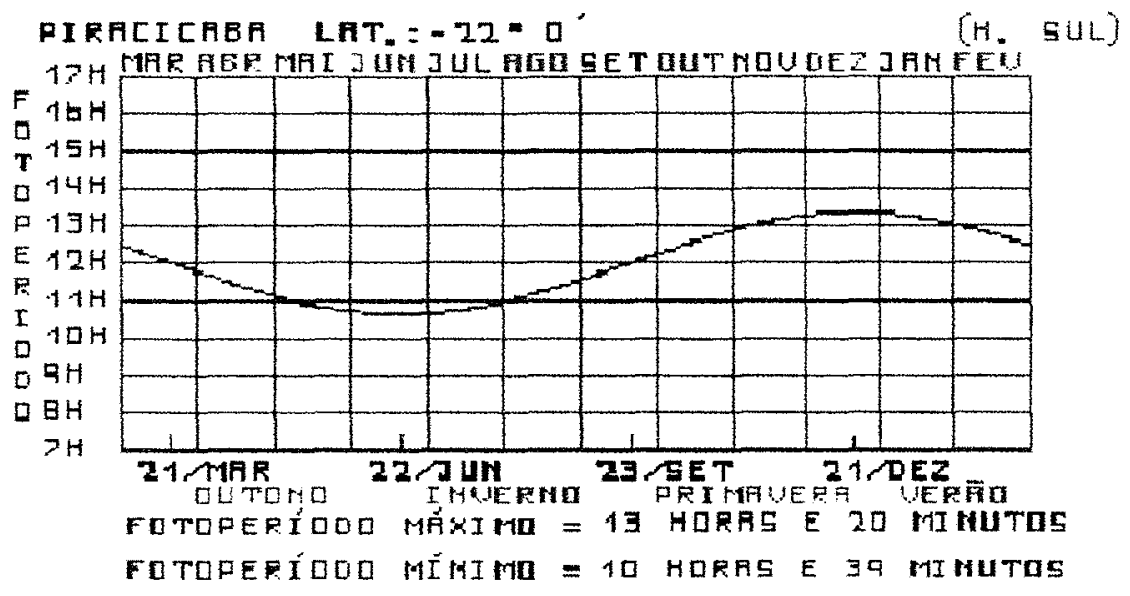

Figura 1. Estimativa do fotoperiodo para a região de Piracicaba.

(Adaptado de Silva, 1992).

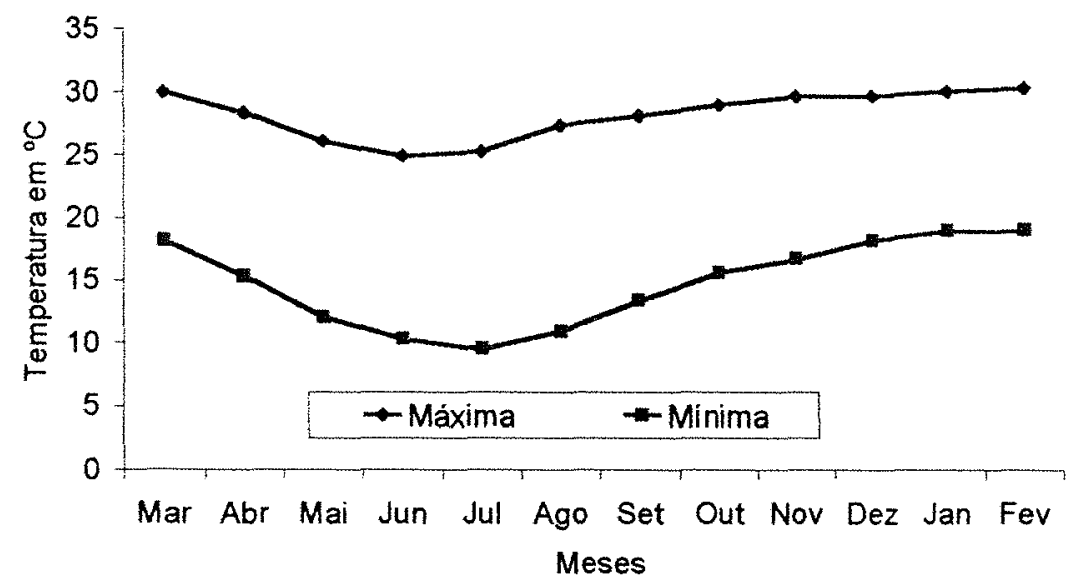

Figura 2. Temperatura Máxima e Minima Médias Mensais no periodo de 1917 a 2000, para a região de Piracicaba (Fonte: Escola Superior de Agricultura "Luiz de Queiroz"-Universidade de São Paulo - Departamento de Ciências Exatas -, 2000) 


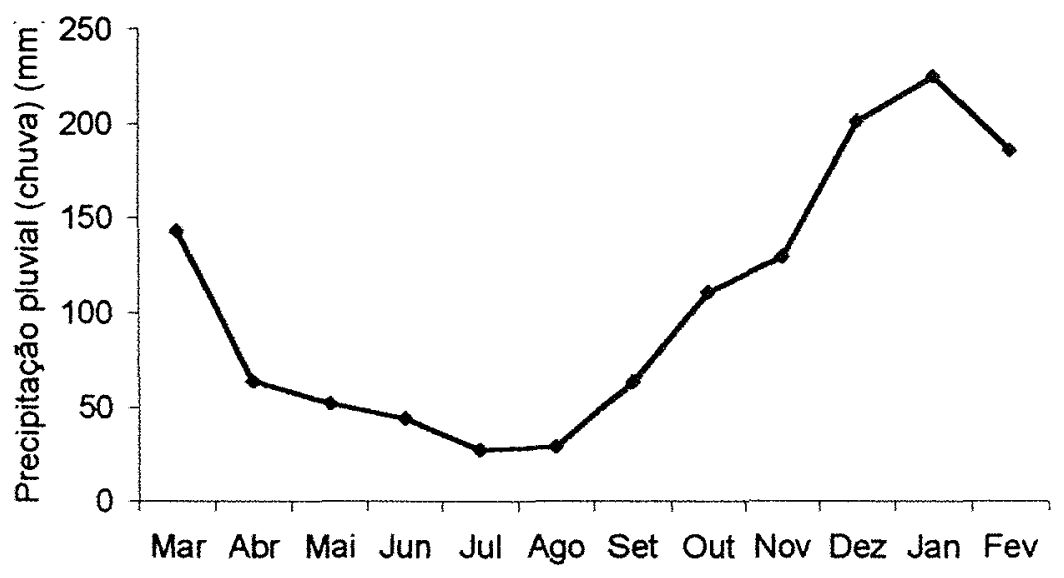

Meses

Figura 3. Precipitação Pluvial Média Mensal (mm) no período de 1917 a 2000, para a região de Piracicaba. (Fonte: ESALQ-USP - Departamento de Ciências Exatas -, 2000)

A semeadura foi realizada durante o ano agrícola 1998/1999 em sete épocas para o cultivar IAC-17 de ciclo semiprecoce (120 a 130 dias), de hábito de crescimento determinado e seis épocas para o cultivar IAC-Foscarin 31 de ciclo precoce (130 a 140 dias) e crescimento indeterminado, ambas recomendadas pela EMBRAPA (1998) para o Estado de São Paulo (Tabela 2).

Tabela 2. Épocas de semeadura do experimento.

\begin{tabular}{cc}
\hline Epoca & Data de semeadura \\
\hline $1^{\circ}$ & $17 / 09 / 98$ (somente IAC 17) \\
$2^{\circ}$ & $02 / 10 / 98$ \\
$3^{\circ}$ & $19 / 10 / 98$ \\
$4^{\circ}$ & $03 / 11 / 98$ \\
$5^{\circ}$ & $17 / 11 / 98$ \\
$6^{\circ}$ & $02 / 12 / 98$ \\
$7^{\circ}$ & $17 / 12 / 98$ \\
\hline
\end{tabular}


O delineamento experimental foi baseado em Câmara (1998a) onde adotou-se o espaçamento de $0,5 \mathrm{~m}$ entrelinhas de soja, com densidade de 20 plantas $\mathrm{m}^{-1} \mathrm{e}$ população final de 400.000 plantas $h^{-1}$. Para se obter a densidade de plantas, aumentou-se o número de sementes distribuidas por parcela em torno de $75 \%$ de maneira a garantir estandes iniciais acima dos valores planejados. Após a emergência, o excesso de plantas de cada linha foi arrancado manualmente para atingir densidade e população desejada. Foram conduzidos sete experimentos individuais e independentes onde cada época de semeadura correspondeu o delineamento experimental em blocos casualizados com três repetições. Cada unidade experimental foi construida por cinco linhas de $5,0 \mathrm{~m}$ de comprimento, sendo as duas linhas extemas e os $0,5 \mathrm{~m}$ de cada extremidade das linhas, consideradas como bordaduras. A área útil de cada parcela foi construída pelas três linhas centrais com $4,0 \mathrm{~m}$ de comprimento cada.

Para o preparo do solo realizou-se uma aração, à profundidade de trinta centímetros, com arado de aivecas reversíveis, seguida de gradagem para destorroamento e nivelamento. A seguir, foi efetuada uma segunda gradagem niveladora para a incorporação dos herbicidas trifuralina e imazaquim aplicados nas doses dos produtos comerciais de $2,0 \mathrm{~L} \mathrm{ha}^{-1}$ e $1,0 \mathrm{~L} \mathrm{ha} \mathrm{L}^{-1}$ antes de cada semeadura.

As sementes da cada cultivar foram tratadas com fungicida Carboxin+Thiram na dose do produto comercial equivalente a $250 \mathrm{ml}$ por $100 \mathrm{~kg}$ de sementes, que foram separadas e acondicionadas. Antes da semeadura houve a aplicação de inoculante turfoso aplicado na dose de $0,4 \mathrm{~kg}$ por $40 \mathrm{~kg}$ de sementes. Após a inoculação, as sementes foram distribuídas manualmente à profundidade de $4,0 \mathrm{~cm}$. A adubação foi determinada a partir da análise química do solo (Tabela 1.) para rendimento da cultura da ordem de $2500 \mathrm{~kg}$ a $3000 \mathrm{~kg} \mathrm{ha}^{-1}$. Aplicou-se 0 equivalente a $400 \mathrm{~kg} \mathrm{ha}^{-1} \mathrm{de}$ fertilizante 00-20-15 correspondente à recomendação de $80 \mathrm{~kg} \cdot \mathrm{ha}{ }^{-1}$ de $\mathrm{P}_{2} \mathrm{O}_{5}$ e 60 de $\mathrm{K}_{2} \mathrm{O}$, proposta por Mascarenhas e Tanaka (1996).

Efetuou-se o controle de plantas daninhas manualmente, por meio de capinas com enxadas e o monitoramento das principais pragas da soja (lagartas desfolhadoras e percevejos) com técnicas do "pano de batida" (Nakano et al., 1988). Houve a incidência de "vaquinha" (Diabrotica speciosa) na terceira época de semeadura e ataque do complexo de percevejos (Nezara viniluda, Piezodorus guildini e Euschistos heros) no enchimento de grãos da mesma época. Para o controle das pragas, 
pulverizou-se o inseticida Endosulfan na dose do produto comercial equivalente a 0,65 L ha ${ }^{-1}$ acrescentado de $0,5 \%$ de solução de $\mathrm{NaCl}$. Promoveu-se a irrigação das parcelas para garantir o desenvolvimento vegetativo e reprodutivo da cultura.

As plantas, da área útil de cada parcela, foram retiradas com roçadora costal, com colheita efetuada na data de maturação plena, ou estádio F8 na Escala Fenológica (Fehr e Caviness, 1977), de cada época. Em seguida foram colocadas ao sol para secagem em terreiro, antes da trilha em máquinas estacionária. A altura das plantas foi determinada em 10 plantas de soja coletadas aleatoriamente em cada parcela em cada estádio da soja. Os grãos foram limpos e acondicionados. A produção de gräos de cada parcela foi pesada e o valor obtido ( $\mathrm{kg}_{\text {parcela }}{ }^{-1}$ ) transformado para rendimento $\left(\mathrm{kg} \mathrm{ha}^{-1}\right)$, corrigido em estufa para a conteúdo de água padrão de $13 \mathrm{~g} 100 \mathrm{~g}^{-1} \mathrm{de}$ massa de grãos.

A análise dos dados de rendimento foi realizada de forma a verificar se existem diferenças estatísticas do rendimento em função da data de semeadura pela análise de regressão polinomial utilizando o Sistema de Análise Estatística (SAS Institute, 1988).

\subsection{RESULTADOS E DISCUSSÃO}

De acordo com a descrição da Escala Fenológica de Fehr e Caviness (1977), as Tabelas 3 e 4 apresentam as datas de ocorrência dos principais estádios de cada cultivar nas diferentes datas de semeadura, altura das plantas e o resumo das condições climáticas, nas épocas estudadas, por meio do fotoperíodo, valores médios de temperatura e precipitação pluvial total por subperiodo fenológico vegetativo entre a emergência e o início do florescimento (VE-VC; VC-V1, V1-R1) e aos subperíodos fenológicos reprodutivos do florescimento (R1-R3), granação (R5-R7) e maturação plena (R7-R8). 
Tabela 3. Data de ocorrência dos principais estádios fenológicos da soja, para o cultivar $I A C$ 17, em dias após a emergência (DAE), e valores de atributos climáticos: radiação global, insolação, fotoperiodo, temperatura máxima, temperatura minima, nas datas de ocorrência do estádio fenológico considerado, precipitação pluvial total em cada subperiodo fenológico.

\begin{tabular}{|c|c|c|c|c|c|c|c|c|c|c|c|}
\hline Epoca de semeadura & $E F$ & Data & DAE & $\begin{array}{l}\text { Altura } \\
(\mathrm{cm}) \\
\end{array}$ & $\begin{array}{l}\text { Radiaçăo Glabal } \\
\text { (callann dia) }\end{array}$ & $\begin{array}{l}\text { Insolaçäo } \\
\text { (h/d) }\end{array}$ & $\begin{array}{l}\text { Fotoper iodo } \\
\text { (h) }\end{array}$ & $\begin{array}{l}\text { Temp Maxima } \\
\left({ }^{\circ} \mathrm{C}\right)\end{array}$ & $\begin{array}{l}\text { Temp Minima } \\
\left({ }^{\circ} \mathrm{C}\right)\end{array}$ & $\begin{array}{l}\text { Temp média } \\
\left({ }^{\circ} \mathrm{C}\right)\end{array}$ & $\begin{array}{l}\text { Precipitacá" } \\
\text { pluvial (mm) }\end{array}$ \\
\hline \multirow{9}{*}{1} & S & $17 / 09 / 98$ & & & 401 & 9,8 & 12,0 & 35,6 & 14,3 & 25,0 & \\
\hline & VE & 2400198 & & & 486 & 9,8 & 12.1 & 30,8 & 11,9 & 21,4 & 36,5 \\
\hline & VC & 28109198 & 2 & & 494 & 8.9 & 12,2 & 30,2 & 115,0 & 226 & 0,0 \\
\hline & $V_{1}$ & $28109 / 98$ & 4 & 5,77 & 110 & 0.0 & 12,2 & 224 & 18,2 & 20,3 & 8,5 \\
\hline & R1 & $09 / 11 / 98$ & 46 & 40,57 & 531 & 9,6 & 13,0 & 31,9 & 17,6 & 24,8 & 192,7 \\
\hline & R3 & $23 / 11 / 98$ & 60 & 46,73 & 372 & 10,4 & 13,2 & 30,8 & 14.4 & 226 & 15,2 \\
\hline & R5 & $01 / 12 / 88$ & 68 & 50,03 & 555 & 11,2 & 13,3 & 34,2 & 16,8 & 25,5 & 9,1 \\
\hline & $R 7$ & $2901 / 189$ & 127 & & 415 & 4,1 & 13,0 & 28,5 & 21,6 & 25,5 & 282,3 \\
\hline & R8 & 0510299 & 134 & & 573 & 8.7 & 12,3 & 33,7 & 198 & 26.8 & 100,0 \\
\hline \multirow{9}{*}{2} & $s$ & $02 / 10 / 98$ & & & 407 & 4,8 & 12,3 & 27.1 & 14,8 & 21,0 & \\
\hline & VE & $0910 / 98$ & & & 359 & 3,5 & 12,3 & 24,4 & 17.8 & 21,1 & 96,4 \\
\hline & VC & $11 / 10 / 98$ & 2 & & 234 & 0,0 & 12,6 & 20,3 & 13,5 & 18,9 & 14,4 \\
\hline & $V_{1}$ & $13 / 10 / 98$ & 4 & 6,63 & 422 & 9,0 & 12,6 & 28,9 & 17,5 & 23,5 & 15.9 \\
\hline & R1 & $16 / 11 / 88$ & 38 & 59,60 & 500 & 10,9 & $\$ 3,1$ & 33,2 & 15,8 & 24,6 & 73,8 \\
\hline & R3 & $27 / 11 / 98$ & 49 & 67,87 & 240 & 0,0 & 13,3 & 26,2 & 20.4 & 23,3 & 8,6 \\
\hline & R5 & $04 \times 1 / 99$ & 87 & 71,69 & 279 & 1,9 & 13,3 & 29,2 & 20,6 & 24,9 & 323,1 \\
\hline & R7 & $14 / 02 / 98$ & 125 & & 306 & 5,5 & 12,8 & 29,4 & 24,0 & 25,2 & 428,1 \\
\hline & $R 8$ & $19102 / 99$ & 133 & & 532 & 7,6 & 312 & 20.7 & 26,0 & & 58,7 \\
\hline \multirow{9}{*}{3} & 5 & 18101088 & & & 507 & 10,9 & 12,6 & 27,7 & 13,7 & 20,7 & \\
\hline & VE & 2814098 & & & 152 & 0,9 & 12,7 & 24,4 & 17,7 & 21,1 & 6,3 \\
\hline & VC & $28 / 10 / 98$ & 2 & & 280 & 3,8 & 128 & 28,9 & 18,4 & 23,7 & 17,2 \\
\hline & VI & $30 / 10138$ & 4 & 6,93 & 125 & 0,0 & 128 & 20,5 & 17,4 & 19,0 & 1,4 \\
\hline & R1 & $04 / 12 / 98$ & 39 & 69.47 & 297 & 1,0 & 13,3 & 29,6 & 20,1 & 24.9 & 30,8 \\
\hline & R3 & $18 / 12 / 88$ & 54 & 90,77 & 389 & 5,3 & 13,3 & 31,1 & 20,4 & 25,8 & 201,2 \\
\hline & R5 & $14 / 01 / 98$ & 80 & 96,40 & 423 & 7,4 & 13,3 & 31,2 & 20,0 & 25,6 & 200,2 \\
\hline & $\mathrm{RT}$ & 25102198 & 122 & & 401 & 5,7 & 12.5 & 30.4 & 20,2 & 25,3 & 349,0 \\
\hline & $\mathrm{RB}$ & $04 / 03 / 99$ & 129 & & 450 & 9,3 & 124 & 320 & 18,4 & 25,2 & 36,0 \\
\hline \multirow{9}{*}{4} & $S$ & $03 / 11 / 98$ & & & 249 & 2,8 & 12,9 & 25,5 & 94,8 & 20,0 & \\
\hline & VE & $0811 / 98$ & & & 431 & 4,8 & 13,0 & 31,9 & 18,5 & 25,2 & 0,0 \\
\hline & vc & $10 / 11 / 88$ & 2 & & 134 & 0,0 & 13,0 & 23,6 & 17,6 & 20,6 & 2,3 \\
\hline & $v_{1}$ & $13 / 11 / 98$ & 5 & 5,80 & 214 & 0,0 & 13,1 & 25,5 & $\$ 5,4$ & 20,5 & 3,2 \\
\hline & $\mathrm{R} 1$ & $22 / 12188$ & 44 & 84,83 & 309 & 1,3 & 13,2 & 28,8 & 20,8 & 24,8 & 231,3 \\
\hline & R3 & $04 / 01 / 99$ & 57 & 86,10 & 279 & 1,9 & 13,3 & 29,2 & 20,6 & 24,9 & 112,4 \\
\hline & R5 & $04 / 02 / 99$ & 88 & 93,40 & 458 & 8,7 & 12,9 & 34,3 & 20.4 & 27,4 & 380,6 \\
\hline & R7 & $02 / 03 / 99$ & 114 & & 394 & 9,1 & 12,4 & 33,0 & 19,5 & 28,2 & 173,2 \\
\hline & R8 & $08 / 03 / 99$ & 121 & & 495 & 9,4 & 12,2 & 326 & 20.0 & 26,3 & 0,0 \\
\hline \multirow{9}{*}{5} & $\mathrm{~s}$ & $17 / 111 / 88$ & & & 434 & 8,4 & 13,1 & 34,0 & 19,2 & 26,6 & \\
\hline & VE & $23 / 11 / 98$ & & & 372 & 10,4 & 13,2 & 30,8 & 14,4 & 226 & 0,0 \\
\hline & VC & $24 / 11 / 88$ & 1 & & 495 & $\$ 1,8$ & 13,3 & 34,0 & 14,2 & 24,1 & 0,0 \\
\hline & V1 & $27 / 11 / 98$ & 4 & 5,93 & 240 & 0,0 & 13,3 & 28,2 & 20,4 & 23,3 & 8,6 \\
\hline & Rq & $04 / 01 / 99$ & 42 & 59,77 & 279 & 1,9 & 13,3 & 29,2 & 20,6 & 24,8 & 323,1 \\
\hline & R3 & 2001199 & 58 & 76,80 & 579 & 10,2 & 13,2 & 36,4 & 20,2 & 28,3 & 217,5 \\
\hline & R5 & 12102109 & 81 & 82,10 & 683 & 91,8 & 128 & 31.8 & 19.4 & 25.6 & 232,3 \\
\hline & $R 7$ & 08103199 & 105 & & 365 & 5,3 & 12,3 & 30.2 & 17.2 & 23,7 & 104,0 \\
\hline & R8 & $1503 / 99$ & 112 & & 485 & 10,0 & 12.1 & 320 & 16,9 & 24,5 & 156.1 \\
\hline \multirow{9}{*}{6} & $\mathrm{~s}$ & $02 / 1288$ & & & 441 & 9,3 & 13,3 & 35,0 & 18,0 & 26,5 & \\
\hline & VE & $07 / 12 / 88$ & & & 538 & 7,3 & 13,4 & 31,0 & 18,5 & 24,8 & 67,6 \\
\hline & VC & $08 / 12 / 98$ & 1 & & 593 & 8,8 & 13,4 & 33,9 & 18,4 & 28,2 & 0,0 \\
\hline & V1 & $10 / 2198$ & 3 & 5,63 & 402 & 5,2 & 13,4 & 31,1 & 20,3 & 25,7 & 32,3 \\
\hline & R1 & $14 / 01 / 99$ & 38 & 59,37 & 423 & 7,4 & 133 & 31,2 & 20.0 & 25,6 & 391,5 \\
\hline & $\mathrm{R3}$ & $11502 / 99$ & 66 & 78,63 & 306 & 5,5 & 12,8 & 29,5 & 21,0 & 25,2 & 257,3 \\
\hline & R5 & $23102 / 98$ & 78 & 78,90 & 330 & 3,4 & 12.6 & 30.4 & 18,4 & 24,4 & 69,3 \\
\hline & R7 & 1403199 & 97 & & 578 & 10,1 & 122 & 28,5 & 14,9 & 21,7 & 214,5 \\
\hline & R8 & 22103199 & 105 & & 416 & 8.1 & 120 & 32.9 & 197 & 26,3 & 8,1 \\
\hline \multirow{9}{*}{7} & $S$ & $17 / 12 / 98$ & & & 203 & 0.4 & 13,3 & 25.8 & 21,2 & 23,5 & \\
\hline & VE & $21 / 12 / 98$ & & & 500 & 9,7 & 13,3 & 34,6 & 17,4 & 26,0 & 0.4 \\
\hline & VC & $23 / 12 / 98$ & 2 & & 195 & 0,0 & 13,3 & 25,1 & 18,6 & 21,8 & 14,8 \\
\hline & $v_{1}$ & $26 / 12 / 98$ & 5 & 7,74 & 591 & 8,7 & 13,3 & 29,4 & 18,8 & 24,2 & 29,6 \\
\hline & R1 & $01 / 02 / 99$ & 42 & 41,87 & 351 & 5.3 & 13,0 & 32,6 & 20,1 & 26,4 & 424,6 \\
\hline & R3 & 1200299 & 53 & 58,47 & 683 & $\$ 1,6$ & 12,8 & 31,8 & 19.4 & 25,6 & 97,0 \\
\hline & R5 & 28102299 & 69 & 58,97 & 388 & 3,8 & 12,5 & 30,1 & 20.0 & 25.1 & 82.4 \\
\hline & $\mathrm{R7}$ & $22103 / 99$ & 91 & & 416 & 8.1 & 12,0 & 32,9 & 197 & 26,3 & 178,6 \\
\hline & $\mathrm{R} 8$ & $29 / 03 / 99$ & 98 & & 348 & 7,3 & 11.8 & 32.8 & 21.2 & 27,0 & 51.1 \\
\hline
\end{tabular}

Fontes: Sentelhas et al. (1998); ESALQN USP - Dep Ciências Exatas (2000) 
Tabela 4. Data de ocorrência dos principais estádios fenológicos da soja, para o cultivar IAC Foscarin 31, em dias após a emergência (DAE), e valores de atributos climáticos: radiação global, insolação, fotoperiodo, temperatura máxima, temperatura minima, nas datas de ocorrência do estádio fenológico considerado, precipitação pluvial total em cada subperíodo fenológico.

\begin{tabular}{|c|c|c|c|c|c|c|c|c|c|c|c|}
\hline Epoca de semeadura & $E F$ & Data & DAE & $\begin{array}{r}\text { Altura } \\
\text { (cn) }\end{array}$ & $\begin{array}{l}\text { Radiactao Global } \\
\text { (cattom }{ }^{2} \text { dia) }\end{array}$ & $\begin{array}{c}\text { Insolaçá } \\
\text { (h/d) }\end{array}$ & $\begin{array}{l}\text { Fotoperiodo } \\
\text { (h) }\end{array}$ & $\begin{array}{l}\text { Temp. Máxima } \\
\left({ }^{\circ} \mathrm{C}\right)\end{array}$ & $\begin{array}{c}\text { Temp Minima } \\
\left({ }^{\circ} \mathrm{C}\right)\end{array}$ & $\begin{array}{c}\text { Temp media } \\
\left({ }^{\circ} \mathrm{C}\right)\end{array}$ & $\begin{array}{l}\text { Precipitaçáo" } \\
\text { pluvial (mm) }\end{array}$ \\
\hline \multirow{9}{*}{2} & $\mathrm{~s}$ & $02 / 10 / 98$ & & & 407 & 4,8 & 12,3 & 27,1 & 14.8 & 21,0 & \\
\hline & VE & $09 / 10 / 98$ & & & 359 & 3,5 & 12,3 & 24,4 & 17.8 & 21,1 & 96,4 \\
\hline & VC & $11 / 10 / 98$ & 2 & & 234 & 0,0 & 12,6 & 20,3 & 13.5 & 16,9 & 14,4 \\
\hline & V1 & $13 / 10 / 98$ & 4 & 4,30 & 422 & 9,0 & 12,6 & 28,9 & 17,5 & 23,2 & 15,9 \\
\hline & R1 & $01 / 12 / 98$ & 53 & 26,63 & 555 & 11,2 & 13,3 & 34,2 & 16,8 & 25,5 & 83,0 \\
\hline & $R 3$ & $16 / 12 / 98$ & 68 & 46,73 & 386 & 5,3 & 13,3 & 31,1 & 20.4 & 25,8 & 201,2 \\
\hline & R5 & $12 / 01 / 99$ & 95 & 108,75 & 144 & 2,3 & 13,3 & 29,8 & 20,0 & 24,9 & 265,1 \\
\hline & R7 & $05 / 02 / 99$ & 119 & 113,29 & 573 & 8.7 & 12.9 & 33.7 & 19.8 & 26,3 & 242,4 \\
\hline & R8 & $12 / 02199$ & 126 & & 683 & 116 & 128 & 318 & 19.4 & 25.6 & 637 \\
\hline \multirow{9}{*}{3} & $s$ & $19 / 10 / 38$ & & & 507 & 10.9 & 12.6 & 27.7 & 13,7 & 20,7 & \\
\hline & VE & $26 / 10 / 98$ & & & 152 & 0,9 & 12.7 & 244 & 17.7 & 21.1 & 6,3 \\
\hline & VC & $28 / 10 / 98$ & 2 & & 269 & 3,8 & 12,8 & 28,9 & 18,4 & 23,7 & 17,2 \\
\hline & V1 & $30 / 10 / 98$ & 4 & 4,60 & 125 & 0,0 & 12.8 & 20,5 & 17,4 & 19,0 & 1,4 \\
\hline & R1 & $16 / 12 / 98$ & 51 & 32,67 & 386 & 5,3 & 13,3 & 31,1 & 20.4 & 25,8 & 232,0 \\
\hline & R3 & $04 / 01 / 99$ & 70 & 61,17 & 279 & 1,9 & 13,3 & 29,2 & 20,6 & 24,9 & 121,4 \\
\hline & R5 & $20 / 01 / 99$ & 86 & 113,50 & 579 & 10,2 & 13,2 & 36,4 & 20,2 & 28,3 & 217,5 \\
\hline & R7 & $15 / 02199$ & 112 & $\$ 21,07$ & 551 & 8,1 & 12,7 & 32,4 & 19,5 & 26.0 & 265.5 \\
\hline & $\mathrm{R} 8$ & 22102199 & 119 & & 215 & 14 & 126 & 26,6 & 20.0 & 23,3 & 12,4 \\
\hline \multirow{9}{*}{4} & s & $03 / 11 / 98$ & & & 249 & 2,8 & 12,9 & 25,2 & 14,8 & 20,0 & \\
\hline & VE & $08 / 11 / 98$ & & & 431 & 4,8 & 13,0 & 31,9 & 18.5 & 25.2 & 0,0 \\
\hline & VC & $10 / 11 / 98$ & 2 & & 134 & 0,0 & 13.0 & 23,6 & 17,6 & 20,6 & 2,3 \\
\hline & $V_{1}$ & $13 / 11 / 98$ & 5 & 5,00 & 214 & 0,0 & 13,1 & 25,5 & 15,4 & 20,5 & 3,2 \\
\hline & R1 & $04 / 01 / 99$ & 57 & 45,07 & 279 & 1.9 & 13.3 & 29,2 & 20,6 & 24,9 & 343.7 \\
\hline & R3 & $12101 / 99$ & 65 & 74,20 & 144 & 2,3 & 13,3 & 29,8 & 20.0 & 24,9 & 143.7 \\
\hline & R5 & $26 / 01 / 99$ & 79 & 105,60 & 341 & 5,8 & 13,1 & 33,3 & 21,1 & 27,2 & 86,1 \\
\hline & R7 & $25 / 02 / 99$ & 109 & 111,23 & 401 & 5,7 & 12,5 & 30,4 & 20,2 & 25,3 & 288,0 \\
\hline & R8 & $04 / 03 / 99$ & 116 & & 450 & 93 & 12,4 & 32,0 & 18,4 & 25,2 & 36,0 \\
\hline \multirow{9}{*}{5} & $\mathrm{~s}$ & $17 / 11 / 98$ & & & 434 & 8,4 & 13,1 & 34,0 & 19,2 & 26,6 & \\
\hline & $V E$ & $23 / 1+/ 98$ & & & 372 & 10.4 & 13.2 & 30,8 & 14,4 & 22.6 & 0,0 \\
\hline & $\mathrm{VC}$ & $24 / 11 / 98$ & 1 & & 495 & 11.9 & 13,3 & 34,0 & 14,2 & 24,1 & 0,0 \\
\hline & V1 & $27 / 11 / 98$ & 4 & 6,20 & 240 & 0,0 & 13,3 & 26,2 & 20,4 & 23,3 & 8,6 \\
\hline & R1 & $12 / 01 / 99$ & 50 & 40.87 & 144 & 2,3 & 13.3 & 29.8 & 20,0 & 24.9 & 466.8 \\
\hline & R3 & $20 / 01 / 99$ & 58 & 77,83 & 579 & 10,2 & 13,2 & 36,4 & 20,2 & 28,3 & 73,8 \\
\hline & R5 & $11 / 02 / 99$ & 80 & 97,10 & 306 & 5.5 & 12.3 & 29,4 & 21,0 & 25,2 & 208,6 \\
\hline & R7 & $12 / 03 / 99$ & 109 & 103,83 & 227 & 0,2 & 12,2 & 25,6 & 20.0 & 22,8 & 282,7 \\
\hline & $\mathrm{R} 8$ & $19 / 03 / 99$ & 116 & & 547 & 9,3 & 12,0 & 31,4 & 18,0 & 24,7 & 2,0 \\
\hline \multirow{9}{*}{6} & $s$ & $02 / 12 / 98$ & & & 441 & 9,3 & 13.3 & 35,0 & 18,0 & 26,5 & \\
\hline & VE & $07 / 12 / 98$ & & & 538 & 7,3 & 13.4 & 31,0 & 18.5 & 24.8 & 67,6 \\
\hline & VC & $08 / 12198$ & 1 & & 593 & 8,8 & 13,4 & 33.9 & 18,4 & 26,2 & 0.0 \\
\hline & $V t$ & $10 / 12 / 98$ & 3 & 4,23 & 402 & 5,2 & $\$ 3,4$ & 31,1 & 20,3 & 25,7 & 32,3 \\
\hline & Rt & $22101 / 99$ & 46 & 34,30 & 677 & 11.0 & 13,2 & 35,1 & 20,8 & 28.0 & 446,2 \\
\hline & $R 3$ & $01 / 02 / 99$ & 56 & 75,37 & 260 & 3,9 & 13,0 & 29,7 & 20,6 & 25,2 & 129,3 \\
\hline & R5 & $12 / 02 / 99$ & 67 & 84,60 & 683 & 11,6 & 12,8 & 31,8 & 19,4 & 25,6 & 97,0 \\
\hline & R7 & $14 / 03 / 99$ & 97 & 87,43 & 576 & 10,1 & 12,2 & 28,5 & 14.9 & 21.7 & 260,1 \\
\hline & $R 8$ & 22103199 & 105 & & 416 & 81 & 120 & 32,9 & 197 & 26,3 & 8,1 \\
\hline \multirow{9}{*}{7} & $s$ & $17 / 12198$ & & & 203 & 0,4 & 13,3 & 25.8 & 21,2 & 23,5 & \\
\hline & VE & $21 / 1298$ & & & 509 & 9.7 & 13.3 & 34,6 & 17,4 & 26.0 & 0,4 \\
\hline & VC & $23 / 12 / 98$ & 2 & & 195 & 0,0 & 13,3 & 25.1 & 18.6 & 21,9 & 14,8 \\
\hline & $V_{1}$ & $26 / 12198$ & 5 & 5,93 & 591 & 8.7 & 13,3 & 29.4 & 18,9 & 24,2 & 29,6 \\
\hline & R1 & $01 / 02 / 99$ & 42 & 39,27 & 351 & 5,3 & 13,0 & 32,6 & 20,1 & 26,4 & 424.6 \\
\hline & R3 & $12 / 02 / 99$ & 53 & 56,67 & 683 & 11,6 & 12,8 & 31,8 & 19,4 & 25,6 & 97,0 \\
\hline & R5 & 28102199 & 69 & 67,10 & 388 & 3,8 & 12,5 & 30.1 & 20,0 & 25,1 & 82,4 \\
\hline & R7 & $22 / 03 / 99$ & 91 & 70.00 & 416 & 8,1 & 120 & 32,9 & 19,7 & 26.3 & 178,6 \\
\hline & $R 8$ & $29 / 03 / 99$ & 98 & & 348 & 7,3 & 11,8 & 32.8 & 21,2 & 27,0 & 51,1 \\
\hline
\end{tabular}


As temperaturas máxima e minima encontram-se dentro do intervalo ideal $\left(20^{\circ} \mathrm{C}\right.$ a $\left.30^{\circ} \mathrm{C}\right)$ para o desenvolvimento pleno da cultura da soja dentro de seu ciclo fenológico (Câmara, 1998b).

O florescimento dos cultivares ocorreu dentro do fotoperiodo de 13,3 horas nas épocas $1,2,3,4, e$ 5. Esse valor de fotoperiodo está dentro da faixa de 13,3 a 13,5 horas, considerada por Marcos e Novembre (1990). A indução ao florescimento nas épocas 6 e 7 ocorreu a medida que houve decréscimo do fotoperiodo, entre os valores de 13,2 e 13 horas.

Uma das caracteristicas visiveis da termo e fotossensibilidade da cultura da soja á altura de plantas em cada subperiodo fenológico. As maiores alturas em R1 de plantas foram obtidas na época 4 , considerada época ideal de semeadura da soja. Em todas as épocas estudadas, a cultivar IAC 17 apresentou plantas mais altas no subperiodo reprodutivo R1 (florescimento) apesar do cultivar IAC Foscarin 31 apresentar maior altura final de planta em R8 (maturação plena). A cultivar IAC 17 pára de crescer no início do florescimento (R1) devido à sua característica de crescimento determinado. A diferença de altura de planta entre R1 e R5 deve-se ao desenvolvimento dos embriões foliares das gemas apicais, que passam de vegetativas a reprodutivas à medida que surgem as primeiras flores.

Apesar da cultivar IAC Foscarin apresentar crescimento indeterminado e continuar seu desenvolvimento vegetativo após o florescimento, as melhores vagens (maior número de sementes por vagem) estão presentes na faixa mediana da planta (Marchiori', 1998).

Os resultados de rendimento obtidos para as duas cultivares apresenta-se na Figura 4 em resposta do tipo de crescimento de cada cultivar, em vista as condições climáticas e altura de plantas.

\footnotetext{
'MARCHIORI, L. F. S. Engenheiro Agrônomo, Mestre em Agronomia, funcionário da Fazenda Areão - unidade de área experimental pertencente à ESALQNSP. Comunicaçäo pessoal.
} 


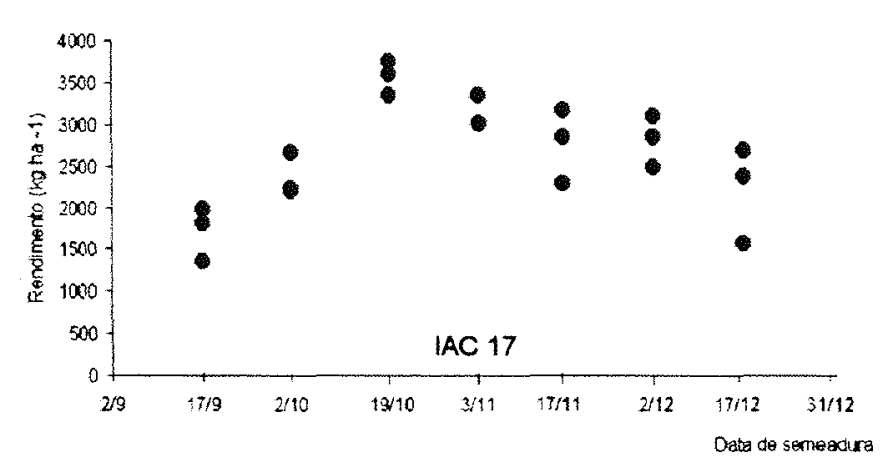

(a)

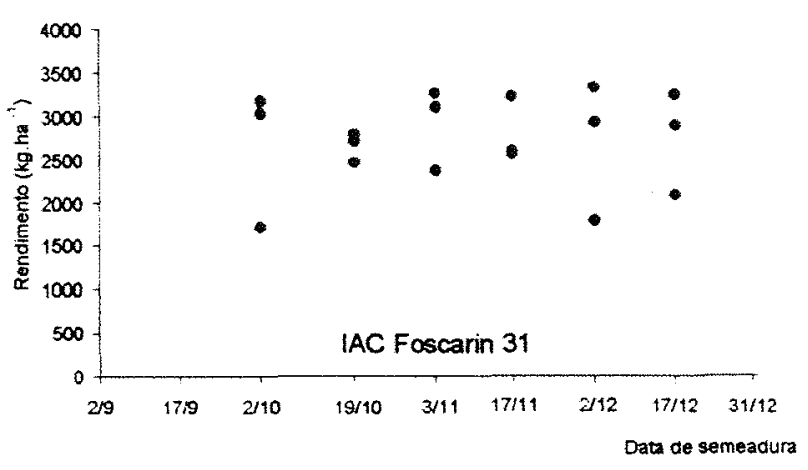

(b)

Figura 4. Tendência de desempenho de rendimento $\left(\mathrm{kg} \mathrm{ha}^{-1}\right)$ em cada parcela, sob diferentes épocas, de semeadura para: (a) cultivar IAC 17; e (b) cultivar IAC Foscarin 31.

Para a cultivar IAC-Foscarin-31, não foi observada diferença estatística (Tabela 5) no rendimento sobre as datas de semeadura. Isso se deve ao fato da cultivar apresentar crescimento indeterminado, obtendo desenvolvimento vegetativo mesmo após o florescimento e granação, o que proporcionou uniformidade de rendimento na colheita. Porém o cultivar apresentou menores rendimentos do que apresentado pela cultivar IAC 17.

Tabela 5. Análise de regressão polinomial com aplicação do teste $F$ para cultivar de soja IAC Foscarin 31.

\begin{tabular}{cccccc}
\hline C.V. & G.L. & SQ & QM & F & Pr>F \\
\hline Reg 1 & 1 & 8576,019 & & 0,003 & 0,8624 \\
Reg 2 & 1 & 54914,286 & & 0,200 & 0,6619 \\
Desvio Reg & 3 & 63490,305 & & 0,120 & 0,8921 \\
(Épocas) & $(5)$ & $(126980,610)$ & & & \\
Residuo & 12 & 4138447,695 & 344870,641 & & \\
\hline Total & 17 & $\mathbf{4 2 6 5 4 2 8 , 3 0 5}$ & & &
\end{tabular}




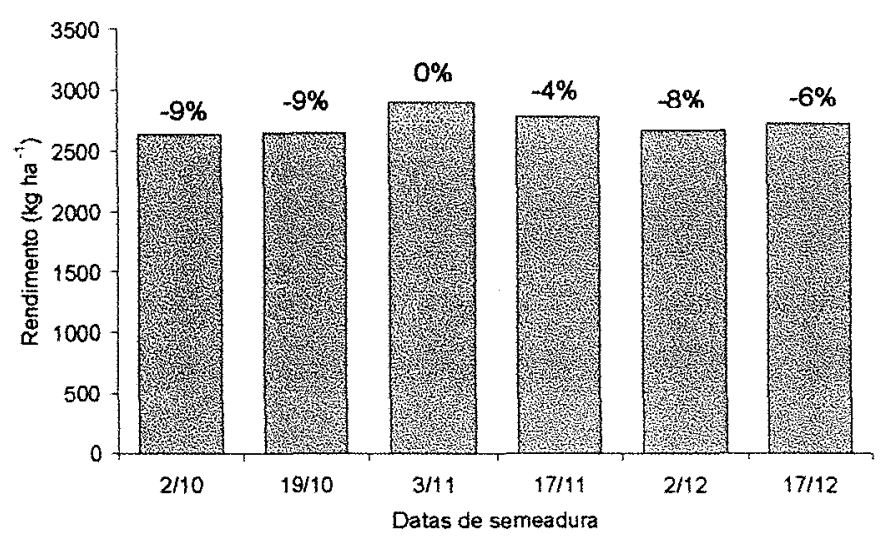

Figura 5. Rendimento da cultivar IAC Foscarin 31 em seis épocas de semeadura e a diferença, em percentagem, do rendimento comparado a melhor época.

Assim, apenas uma análise da percentual pode ser realizada para comparação entre as médias de rendimento obtidas fora da data considerada ótima. As maiores perdas por pontualidade na semeadura ocorreram nas datas anteriores à ótima $(9 \%)$ (Figura 5). Para a modelagem, esses valores de rendimento podem ser utilizados em um periodo de semeadura preestabelecido, não sendo possivel estimar as perdas diárias de rendimento da cultivar.

A cultivar IAC 17 apresentou diferenças significativas ao nivel de $5 \%$ pelo teste $F$ (Tabela 6) entre as diferentes épocas de semeadura. $O$ desempenho da cultivar em função das datas (Figura 6) pode ser representado por modelo polinomial de até quarto grau, devido ao desvio da regressão (Desvio Reg) ser significativo, porém o modelo que melhor representa a resposta do cultivar a épocas de semeadura é a equação de segundo grau (Equação 1).

Tabela 6. Análise de regressão polinomial com aplicação do teste $F$ para cultivar de soja IAC 17.

\begin{tabular}{cccccc}
\hline C.V. & G.L. & SQ & QM & F & Pr>F \\
\hline Reg 1 & 1 & 251050,8 & & 1,400 & 0,2525 \\
Reg 2 & 1 & 4987407,1 & & 27,770 & $0,0001^{*}$ \\
Desvio Reg & 4 & 5238457,9 & & 14,580 & $0,0002^{*}$ \\
(Épocas) & $(6)$ & $(10476915,8)$ & & & \\
Resíduo & 14 & 3232954,4 & 230925,3 & & \\
\hline Total & 20 & 13709870,2 & & & \\
significativo a 5\% & & & &
\end{tabular}




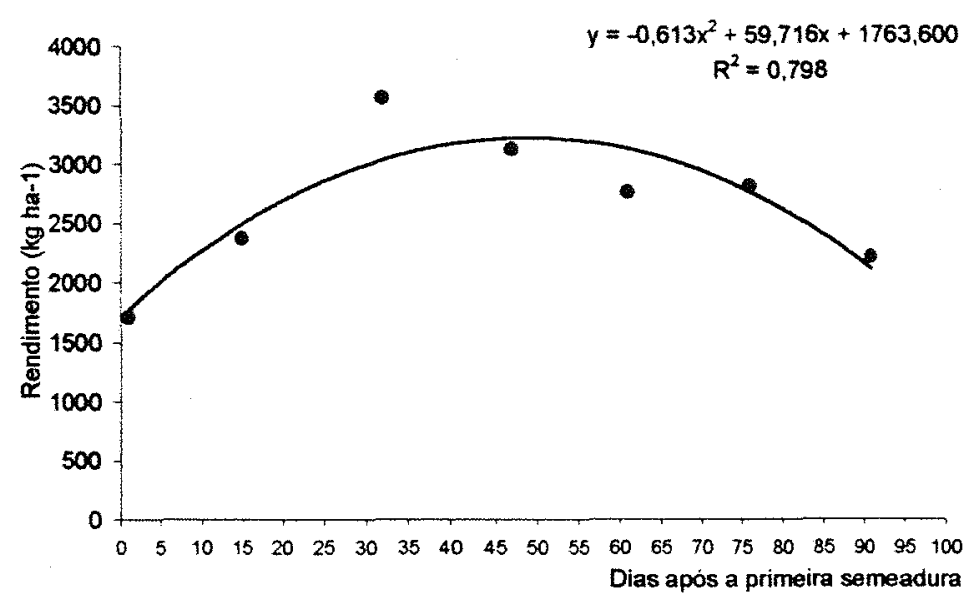

Figura 6. Desempenho de rendimento médio $\left(\mathrm{kg} \mathrm{ha}^{-1}\right)$ para a cultivar IAC $17 \mathrm{em}$ função de dias para a região de Piracicaba.

$$
Y=-0,613 X^{2}+59,716 X+1763,600
$$

Em que: $Y$ - rendimento da cultura da soja, $\mathrm{kg} \mathrm{ha}^{-1} ; \mathrm{X}$ - dias após a primeira data de semeadura.

Modelo matemático do rendimento médio $\left(\mathrm{kg} \mathrm{ha}^{-1}\right)$ para a cultivar IAC $17 \mathrm{em}$ função de dias para a região de Piracicaba demonstra que o baixo rendimento da cultivar |AC-17 fora da época ideal de semeadura se deve ao fato da cultivar apresentar juvenilidade longa e fotoperiodo crítico, induzindo ao florescimento e granação, finalizando o desenvolvimento vegetativo, característica de cultivares de crescimento determinado, de acordo com Câmara (1998b).

O número de dias após a primeira data de semeadura que proporciona o máximo rendimento da soja, de acordo com o modelo, foi dado pela maximização da função de rendimento obtido (Equação 2), correspondendo a 49 dias após a primeira semeadura com um rendimento médio estimado de $3218 \mathrm{~kg} \mathrm{ha}^{-1}$. Caso a cultivar IAC 17 seja semeada no início ou final do periodo, perdas da ordem de $50 \%$ podem ser esperadas em relação a data ótima. $A$ diferença de rendimento entre as duas cultivares é de $316 \mathrm{~kg} \mathrm{ha}^{-1} \mathrm{em}$ favor da cultivar IAC 17, para a data ótima. Com relação aos extremos a cultivar IAC Foscarin 31 produz mais, na ordem de $269 \mathrm{~kg} \mathrm{ha}^{-1}$ para a semeadura "cedo" e $519 \mathrm{~kg} \mathrm{ha-1}$ para a semeadura "tardia". 


$$
59,716-1,226 \mathrm{X}=0
$$

Em que $X=$ número de dias após a primeira data de semeadura.

$\mathrm{Na}$ Tabela 7 são apresentadas as diferenças de rendimento em relação ao ótimo, para periodos semanais, representando a semeadura "cedo" e "tardia", destacando o dia de máximo rendimento esperado da soja. Perdas de até $50 \%$ podem ser previstas pela Equação 1.

Tabela 7.. Rendimento esperado por semana de semeadura para a cultivar IAC 17 , obtidos através da Equação 1 e das perdas na semeadura (\%).

\begin{tabular}{ccc}
\hline Datas & $\begin{array}{c}\text { Rendimento esperado por } \\
\text { semana }\left(\mathrm{kg} \mathrm{ha}^{-1}\right)\end{array}$ & Diferença (\%) \\
\hline $24 / 09 / 98$ & 2152 & $-50 \%$ \\
$01 / 10 / 98$ & 2479 & $-30 \%$ \\
$08 / 10 / 98$ & 2747 & $-17 \%$ \\
$15 / 10 / 98$ & 2955 & $-9 \%$ \\
$22 / 10 / 98$ & 3103 & $-4 \%$ \\
$29 / 10 / 98$ & 3190 & $-1 \%$ \\
$05 / 11 / 98$ & 3218 & - \\
$12 / 11 / 98$ & 3185 & $-1 \%$ \\
$19 / 11 / 98$ & 3093 & $-4 \%$ \\
$26 / 11 / 98$ & 2940 & $-9 \%$ \\
$03 / 12 / 98$ & 2727 & $-18 \%$ \\
$10 / 12 / 98$ & 2454 & $-30 \%$ \\
$17 / 12 / 98$ & 2122 & $-50 \%$ \\
\hline
\end{tabular}

Com o modelo matemático de estimativa de rendimento é possível realizar o gerenciamento das atividades agrícolas de acordo com os prazos de semeadura prédeterminados. Já para a cultivar IAC-Foscarin 31, o rendimento independe da época de semeadura estabelecida, trazendo o mesmo retomo econômico para diferentes situações de planejamento. Para maior previsibilidade de retomo econômico, a equação de rendimento da cultivar IAC 17 estabelece o planejamento adequado para que a produção de soja seja viável. Pela simplicidade de modelagem de rendimento da 
cultura da soja, essa metodologia pode ser empregada em outros cultivares em diferentes regiões, tendo em vista o planejamento das atividades agrícolas.

\subsection{CONCLUSÕES}

A cultivar de soja IAC Foscarin 31 não apresentou diferença significativa de rendimento para o período de semeadura adotado, ao contrário da IAC 17.

$O$ modelo de regressão que melhor se ajustou aos dados para a IAC 17 foi $O$ polinomial de segundo grau, permitindo inferir o rendimento de acordo com a data de semeadura da cultura. Queda de rendimento de até $50 \%$ em função da data de semeadura foram previstas pelo modelo matemático.

A cultivar IAC Foscarin apresentou maior rendimento na semeadura "cedo" $e$ "tardia" em relação ao cultivar IAC 17, caracterizando a importância da prática da semeadura de cultivares de diferentes hábitos de crescimento ou grupo de maturação numa mesma propriedade, diminuindo a interferência da pontualidade em máquinas agricolas. 


\section{DESENVOLVIMENTO DE UM MODELO EMPÍRICO PARA A SELEÇÃO DE MÁQUINAS AGRICOLAS NA CULTURA DA SOJA, CONSIDERANDO A PONTUALIDADE NA SEMEADURA}

\section{RESUMO}

O Brasil é o segundo produtor mundial de soja, com 31 milhões de toneladas. No pais é uma das culturas que mais se utiliza a mecanização, podendo esse item atingir a $40 \%$ do custo total de produção. Das operações realizadas, a semeadura é crítica devido a sensibilidade da soja ao fotoperíodo e temperatura. Efetuada fora de época, afeta o rendimento; se for no periodo ideal, visando o rendimento máximo, 0 custo da mecanização pode inviabilizar o investimento. Tendo em vista essas restrições, o trabalho tem o objetivo desenvolver um modelo empirico para a seleção de máquinas agrícolas para a cultura da soja. Construído em MS Visual Basic 6 , calcula a receita parcial, considerando a pontualidade na semeadura. A rotina foi verificada quanto a possíveis erros e a validação feita comparando-se os resultados do programa com valores da literatura. As vantagens do programa referem-se ao calculo do custo fixo com base nas horas efetivamente trabalhadas e do número de equipamentos com base na pontualidade. 


\section{SUMMARY}

\section{AN EMPIRICAL MODEL FOR CHOOSING FARM MACHINERY IN SOYBEAN CROP, CONSIDERING TIMELINESS COSTS}

Brazil is the second world producer of soybean with 31 millions of tons. In the country it is one of cultures in which mechanization is more utilized and the cost of this item reach $40 \%$ of the total production cost. The sowing period is critical because of the sensibility in respect to climate conditions. Earlier or later establishment may affects the yield; executed in the ideal sowing period, aiming at the maximum yield, may cause the investment impracticable due to mechanization costs. Considering these restrictions, the work has the aim to develop a model to select agricultural machinery for soybean culture, discussing its advantages and limitations. Built in MS Visual Basic 6 it calculates a partial income, taking in consideration the timeliness in the sowing operation. The routine was verified as to possible errors and the validation made comparing the programs results with literature value. The advantages of the program refer to the calculations of the fixed costs based on effective working hours and partial income based on timeliness.

\subsection{INTRODUÇÃO}

A mecanização na cultura da soja representa grande parte dos custos de produção. Os custos diretos referentes ao uso de máquinas agricolas podem chegar a $40 \%$ dos custos de produção de soja no plantio convencional e $30 \%$ no plantio direto (FNP, 1998). As estimativas referentes aos custos indiretos, definido como aquele causado pelas perdas na produção devido a não realização das operações agricolas nos prazos determinados (Hunt, 1974; Witney, 1988), ainda são desconhecidos para as condições do país. A quantidade de máquinas disponiveis no mercado e os custos indiretos associados à pontualidade das operações torna a seleção de sistemas mecanizados uma atividade complexa. A modelagem desses sistemas, como um recurso auxiliar para a tomada de decisão, permite com que as variáveis envolvidas sejam estudadas e avaliadas quanto a importância na composição dos custos de 
produção (Burrows e Siemens, 1974; Edwards e Boejlhe, 1981; Milan, 1992). A pontualidade na cultura da soja pode ser quantificada em cada processo de seu manejo, como as perdas referentes a época de preparo do solo (Elmore, 1990), de semeadura (Câmara,1998), de controle de plantas daninhas (Fleck et al., 1997), de controle de doenças e pragas (Gazzoni, 1998) e época de colheita (Santos, 1996). Dos aspectos relacionados ao manejo cultural, merece atenção a época de semeadura. 0 fato de a soja ser considerada uma cultura termo e fotossensivel, quando suas exigências climáticas não são atendidas, a planta está sujeita a alterações fisiológicas e morfológicas afetando o rendimento e arquitetura da planta (EMBRAPA, 1998). Tendo em vista a importância da soja, as restrições relacionadas ao fotoperiodo critico, o trabalho tem como objetivo desenvolver um modelo empirico para a seleção de máquinas agricolas para a cultura da soja considerando a pontualidade na semeadura, discutindo suas vantagens e limitações.

\subsection{MATERIAL E MÉTODOS}

O modelo foi desenvolvido em MS Visual Basic 6.0, de acordo com fluxograma apresentado na Figura 7. Os dados de entrada (1) para o funcionamento do modelo referem-se ao tamanho da área, período de planejamento da safra e tipo de solo e preparo, com operações mecanizadas pertinentes à escolha, tais como aração, calagem, gradagem, aplicação de herbicida e inseticida.

O usuário determina o periodo de semeadura, cuja função é definir o rendimento da cultura (2), de acordo com o modelo de regressão (Equação 1) para o cultivar de soja IAC-17 em sete épocas de semeadura (17/09/98, 02/10/98, 19/10/98, 03/11/98, 17/11/98, 02/12/98 e 17/12/98) para a região de Piracicaba.

As datas de inicio e témino das atividades mecanizadas (3) são determinadas pelo modelo e variam de acordo com a data de semeadura (Tabela 8). Com a entrada do número de dias úteis de cada mês do ano agrícola é calculado o tempo disponível (4), de acordo com metodologia de Mialhe (1974) 


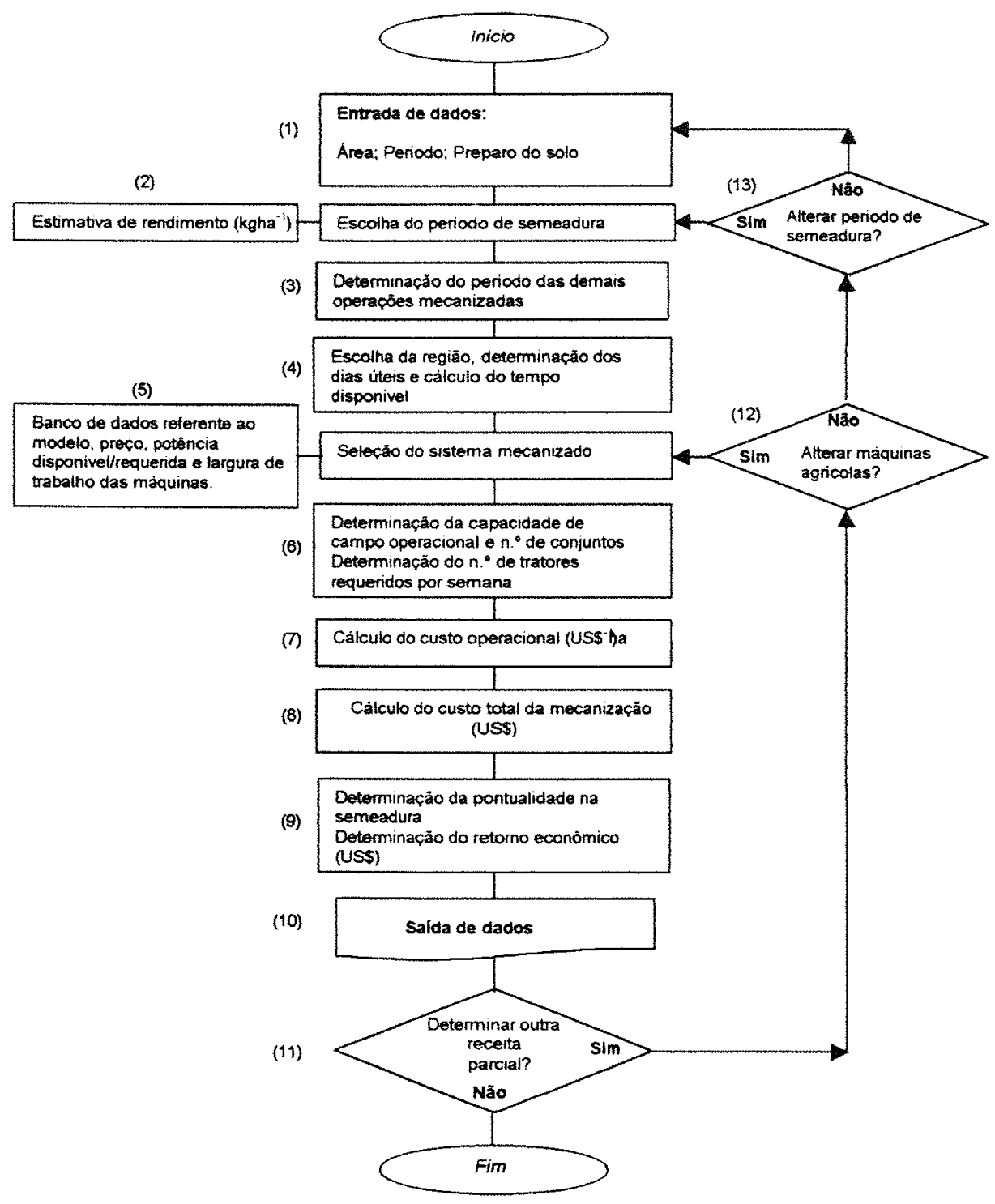

Figura 7. Fluxograma do modelo. 
Tabela 8. Planejamento das atividades agricolas de acordo com a época de semeadura.

\begin{tabular}{|c|c|}
\hline Operação & Época indicada \\
\hline Preparo do solo & Até 10 dias antes do início da semeadura \\
\hline $\begin{array}{c}\text { Aplicação de herbicida em pré- } \\
\text { emergência }\end{array}$ & Até 3 dias antes do início da semeadura \\
\hline $\begin{array}{c}\text { Aplicação de herbicida em pós- } \\
\text { emergência }\end{array}$ & De 15 a 25 dias após a semeadura \\
\hline Aplicação de inseticida & De 25 a 90 dias após a semeadura \\
\hline Colheita & De 120 a 140 dias após a semeadura \\
\hline
\end{tabular}

Fonte: $\mathrm{BASF}^{2}$

A seleção do sistema mecanizado é realizada através de um banco de dados (5). Os tratores encontram-se em três faixas de potência, $56 \mathrm{~kW}, 67 \mathrm{~kW}$ e $89 \mathrm{~kW}$, aqui denominadas de baixa, média e alta potência, respectivamente. A escolha dos implementos disponível do banco de dados é aquela correspondente à faixa de potência selecionada, de acordo com recomendação dos catálogos de fabricantes. As faixas de potência das colhedoras foram divididas em dois grupos: de $74 \mathrm{~kW}$ a $147 \mathrm{~kW}$ e de $148 \mathrm{~kW}$ a $185 \mathrm{~kW}$. Os preços das máquinas e suas respectivas características foram extraidos do FNP (1998).

A capacidade operacional a campo e o número de conjuntos por semana são calculados de acordo com metodologia adotada por Mialhe (1974). Com o número máximo de tratores requeridos por semana tem-se a frota final para o cálculo do custo da mecanização (6).

Os custos diretos das máquinas utilizadas foram obtidos de acordo com a ASAE (1996). Os custos operacionais foram calculados a partir das horas de uso das máquinas segundo as requeridas no planejamento (7). Com a somatória dos custos operacionais de todas as operações, multiplicada pela área, tem-se o custo total de mecanização (8). A pontualidade associada à semeadura (9) é obtida de acordo com a Equação 3.

\footnotetext{
${ }^{2}$ BASF - O Brasil já collhe o futuro (folheto)
} 


$$
R E=\left[\sum_{i=1}^{n}\left(A_{i} \times R d_{i}\right)\right] \times P S
$$

Em que: RE - retomo econômico da soja, US\$; $n$ - número de semanas dentro do periodo de semeadura; $A_{i}$ - área trabalhada na semana $i$, ha; $R_{i}$ - rendimento esperado na semana i, $\mathrm{kg} \mathrm{ha}^{-1}$; Ps - preço da soja, US\$ $\mathrm{kg}^{-1}$.

A saida de dados (10) refere-se à diferença entre o retomo econômico da soja e o custo total de mecanização, finalizando-se um cenário (11). As novas simulações, para os mesmos dados de entrada podem ocorrer na mudança referentes às caracteristicas dos conjuntos mecanizados (12) ou a época de semeadura (13) para incremento da receita parcial. Os formulários e parte da rotina do modelo computacional encontram-se no Anexo A e Anexo B.

A rotina foi verificada quanto a erros nas etapas intermediárias do programa. Com a utilização de 1000 horas de uso para tratores e colhedoras e 500 horas para implementos, foi realizada a validação do modelo pela comparação dos resultados com valores fomecidos pela literatura e por uma propriedade agrícola produtora de soja no estado de São Paulo.

\subsection{RESULTADOS E DISCUSSÃO}

Não foram verificados erros na rotina do programa quanto ao cálculo do rendimento da cultura, dos custos operacionais e da receita parcial. Os dados de entrada para a comparação dos resultados obtidos referiram-se a uma área de 4700 ha, para a safra agrícola de 01/08/1998 a 31/03/1999, com período de semeadura compreendido entre 17/09/1998 a 17/12/1998. Foram estudados três cenários básicos para validação do modelo em relação ao custo operacional das máquinas onde o Cenário-A refere-se à potência de $56 \mathrm{~kW}$ e $100 \mathrm{~kW}$; Cenário-B a $67 \mathrm{~kW}$ e $111 \mathrm{~kW}$; Cenário-C a $89 \mathrm{~kW}$ e $155 \mathrm{~kW}$ para tratores e colhedoras, respectivamente.

A validação efetuada através da comparação dos resultados, demonstrou que para a faixa de potência de $89 \mathrm{~kW}$ o programa calcula os custos operacionais com uma diferença $2 \%$ inferior em relação aos dados fornecidos pela FNP (1998) e $10 \%$ 
inferiores aos fornecidos pela propriedade agricola. A EMBRAPA (1997a) fornece um custo de mecanização para a soja na ordem de US\$ ha-1 78,31 sem especificar 0 sistema utilizado; o programa forneceu valores de US\$ ha-1 77,41, US\$ ha $a^{-1} 84,68$ e US $\$ \mathrm{ha}^{-1} 98,61$ para as potências de $56 \mathrm{~kW}, 67 \mathrm{~kW}$ e $89 \mathrm{~kW}$, representando diferenças de $-1 \%, 8 \%$ e $25 \%$, respectivamente, em relação aos valores da EMBRAPA (1997a) (Figura 8). Em seguida, os custos das operaçōes mecanizadas foram validados individualmente, (Figura 9) demonstrando que o modelo apresenta a mesma tendência de custos em relação aos dados de literatura e da propriedade agricola. As diferenças podem ser consideradas adequadas em função das variáveis que influem no trabalho agricola. Sobressaem-se os custos operacionais da aração obtidos no modelo, pois apresenta menor capacidade operacional a campo, conseqüencia da largura de trabalho, comparado a outras operações. Os custos operacionais da colheita da propriedade apresentam-se maiores que a tendência obtida no modelo e na literatura devido à terceirização do serviço e a inclusão do preço do aluguel nas estimativas de custos.

Uma das características básicas do modelo refere-se a obtenção dos custos do sistema mecanizado em função das horas trabalhadas na cultura e não de uma estimativa anual. Uma segunda é de que o modelo permite calcular renda parcial, através da estimativa de rendimento em função da época de semeadura. Através da utilização interativa do programa, o usuário pode estimar o melhor periodo de semeadura e com isso o modelo define a necessidade de conjuntos mecanizados para atender aos prazos das operações. A principal limitação do modelo computacional está no fato de que as datas das operações não podem ser alteradas, excetuando-se a semeadura. Isso implica que não existe a possibilidade de avaliar a frota para toda as operações. As altemativas a essa limitação ficam condicionadas a mudanças na faixa de potência, largura de trabalho dos implementos, jomada de trabalho e tipo de preparo de solo. 


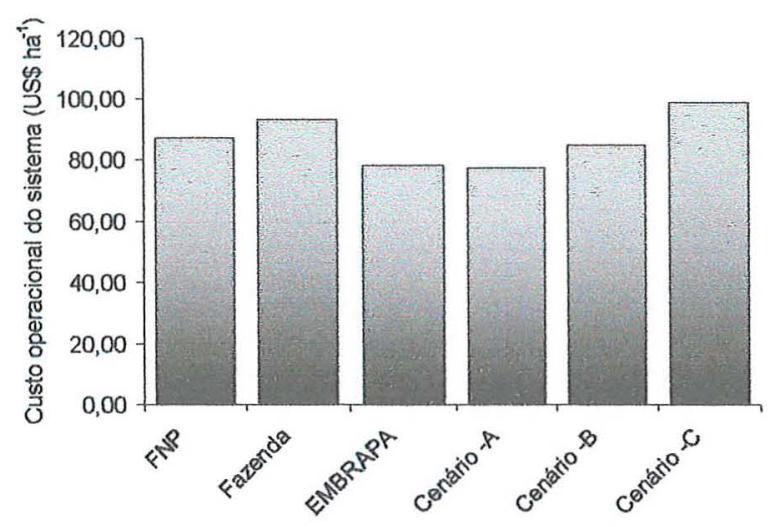

Figura 8. Validação do modelo em relação ao custo operacional (US\$ ha ${ }^{-1}$ ) em comparação com resultados obtidos em literatura e numa propriedade agrícola produtora de soja.

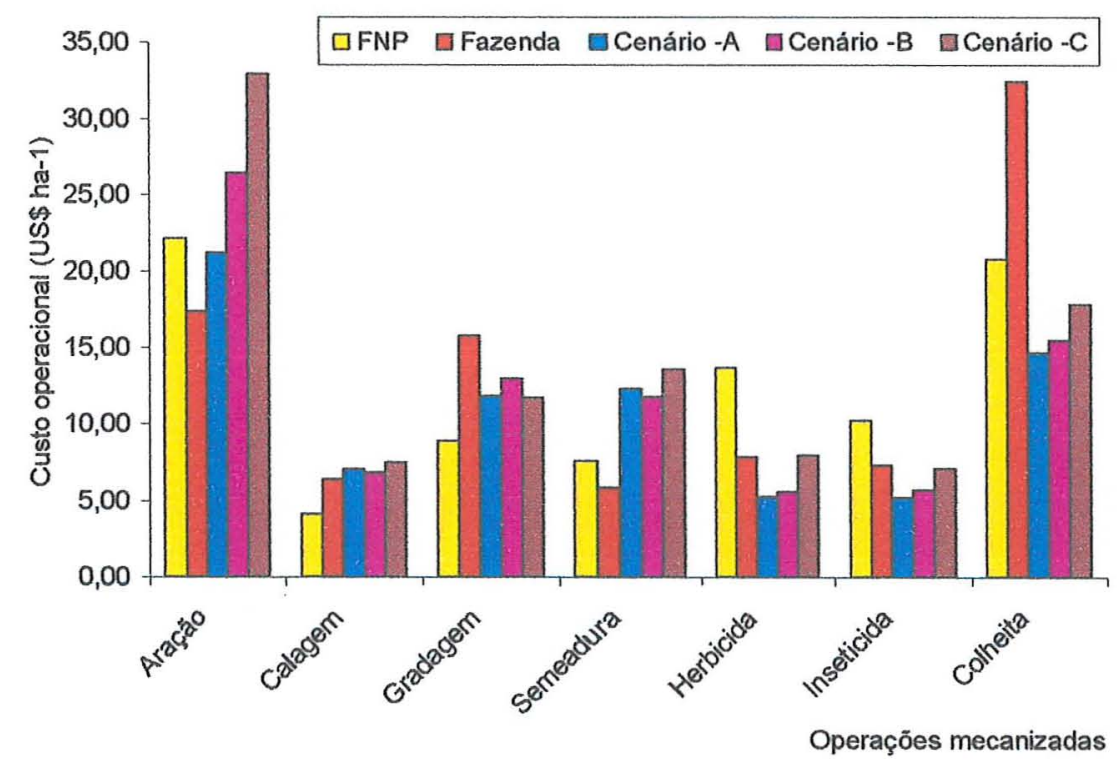

Figura 9. Validação do modelo em relação ao custo operacional nas operações mecanizadas (US\$ ha-1), em comparação com resultados obtidos em literatura e numa propriedade agrícola produtora de soja. 


\subsection{CONCLUSÖES}

O modelo mostrou-se adequado com relação a rotina e aos resultados obtidos. As vantagens do programa referem-se a obtençäo dos custos considerando-se somente às horas de uso das máquinas aplicadas a cultura e por considerar a pontualidade. A limitação principal é a fixação nas datas das operações, excetuando-se a semeadura, mas alternativas podem ser utilizadas no desenvolvimento de cenários. 


\section{A PONTUALIDADE NA SEMEADURA DA SOJA E SEU EFEITO NO NÚMERO DE MÁQUINAS, RETORNO ECONÔMICO, CUSTO DE MECANIZAÇÃO E RECEITA PARCIAL}

\section{RESUMO}

Estima-se que os custos diretos no uso de máquinas agrícolas na cultura da soja estejam em $40 \%$ dos custos de produção e os de pontualidade, ou indiretos, são desconhecidos. A pontualidade determina o prazo em que as operações devem ser realizadas, ocorrendo perdas caso isso não aconteça. Como a época de semeadura determina o desenvolvimento da cultura, há de se priorizar essa operação. $O$ objetivo desse trabalho é de analisar o efeito da pontualidade no número de máquinas, retorno econômico promovido pela cultura, custo de mecanização e receita parcial. Para tanto, foi utilizado um modelo empírico desenvolvido para a seleção de máquinas agrícolas na cultura da soja, com variação no tamanho de área e faixa de potência, na ordem crescente de aumento do número de semanas destinadas à semeadura. Os resultados gerados de diversas simulações demonstraram: que a faixa de potência interfere no custo de mecanização, apesar da diferença do preço inicial das máquinas; o tamanho da área interfere no número de máquinas necessárias para a realização das operações; quanto maior o prazo destinado à semeadura, menor o custo de mecanização e maior a receita obtida, para as condições estudadas. 


\section{SUMMARY}

\section{TIMELINESS AT SOYBEAN SOWING AND ITSI EFFECTS AT MACHINERY NUMBER, YIELDED ECONOMIC RETURN, MECHANIZATION COST AND PARTIAL INCOME}

Direct costs for soybean are $40 \%$ of total production cost. Timeliness is measurement of the specific time that given field operation must occur in order to reduce yield losses and is unknown for the Brazilian conditions. As the sowed time determines the development of culture, it must prioritize that operation. The objective of this work was to analyze the timeliness at soybean sowing effects of machinery number, yielded economic retum, mechanization cost and partial income. An empiric model developed for machinery selection at soybean was used. The scenarios were based at area size, power trial and sowing period. Several simulations demonstrated: that the tractor power interferes in the mechanization cost, in spite of machines initial price; the area size increases the machinery number required; the greater sowing period reduces mechanization cost and increases the partial income, at studied conditions.

\subsection{INTRODUÇÃO}

De acordo com Balastreire (1987), a pontualidade, em máquinas agrícolas, é definida como a capacidade de efetuar as operações na época em que a qualidade e a quantidade de um produto são otimizadas. O conhecimento da interação entre os efeitos da data de semeadura e colheita, sobre o rendimento, pode otimizar as combinações das operações, levando a minimização das perdas por pontualidade considerada como custo indireto da maquinaria agricola (Chancellor e Cervinka, 1974). O levantamento dessas perdas por prazo de operação é extremamente útil para a seleção da maquinaria agrícola, evitando-se o superdimensionamento do número de conjuntos, aumento da faixa de potência ou sobrecarga de trabalho para um trator agricola (Witney, 1988). 
Segundo Hunt (1974) a mesma cultura pode apresentar rendimentos diferentes dependendo da região e da variedade utilizada. Assim o fator de perda por pontualidade, associado às operações mecanizadas, deve ser determinado para cada local. Para tanto, os modelos que simulam as diferentes fases de crescimento e rendimento da cultura em função do tipo de solo, clima, manejo entre outros, podem ser associados ao planejamento das atividades agricolas na avaliação da pontualidade (Hoogerboom et al., 1992).

Em alguns modelos desenvolvidos para otimizar a seleção de máquinas agricolas na cultura da soja e milho considera-se a pontualidade pelas perdas por dia decorrentes do atraso das operações mecanizadas, em especial, a época de semeadura (Burrows e Siemens, 1974, Edwards e Boejlhe 1980, Lal et al., 1992). No caso a soja apresenta termo e fotossensibilidade e quando suas exigências climáticas não são atendidas, como por exemplo o atraso da semeadura, ocorrem a alterações fisiológicas e morfológicas que afetam o seu rendimento, caracterizando o custo indireto devido a operação mecanizada. (EMBRAPA, 1997b).

No Brasil, segundo maior produtor de soja com 31 milhões de toneladas produzidas na safra 1998/1999 (EMBRAPA, 1998), ainda não existem estudos referentes a influência da pontualidade sobre o custo de mecanização. Sendo assim, o objetivo desse trabalho foi de analisar o efeito da pontualidade, referente a operação de semeadura da soja, sobre o número de conjuntos mecanizados, o custo final de mecanização, e na receita parcial.

\subsection{MATERIAL E MÉTODOS}

Para a realização do trabalho foi utilizado um microcomputador Microtec com 64 MB de memória RAM e processador Pentium II, no qual foi instalado um programa de seleção de máquinas agrícolas para a cultura da soja, desenvolvido no Capitulo 4, que considera a pontualidade na operação de semeadura, com a Equação 1 desenvolvido 
no Capitulo 3, onde o fluxograma básico, com a saída de dados, é apresentado na Figura 10.

No programa o usuário fomece os dados relativos: a propriedade (1), periodo de semeadura para a cultivar IAC 17 (2), realização das operações agrícolas (3) e clima (4). A seguir seleciona a faixa de potência dos tratores (5) e programa calcula o número de conjuntos por semana (6). o custo operacional (7) e total da mecanização (8). A pontualidade é determinada pelo retorno econômico (9), dado pela Equação 3 , para a obtenção da receita parcial (10), que é a diferença entre o retorno econômico e o custo de mecanização. Caso o usuário deseje, podem ser realizados novos cálculos (11), alterando o sistema mecanizado (12), as datas de semeadura (13) ou os dados referentes a propriedade (14). Os resultados finais (15) são emitidos na forma de planilha contendo o tamanho da área, custo de mecanização, a receita parcial, o retomo econômico, a necessidade semanal de tratores e as máquinas selecionadas. Os formulários do modelo computacional e parte de sua rotina apresentam-se nos Anexos $A$ e B.

Para o presente trabalho os dados referentes ao planejamento das operações agrícolas para a cultura da soja são apresentados na Tabela 9 . A seleção de máquinas foi realizada com base em três faixas de potência para tratores, visando o preparo de solo convencional, sem a operação de colheita, devido ao alto preço inicial das máquinas. Os tratores e implementos são apresentados na Tabela 10, com respectivo preço inicial. Os períodos de semeadura considerados e que definem o rendimento da cultura, são apresentados na Tabela 11. 


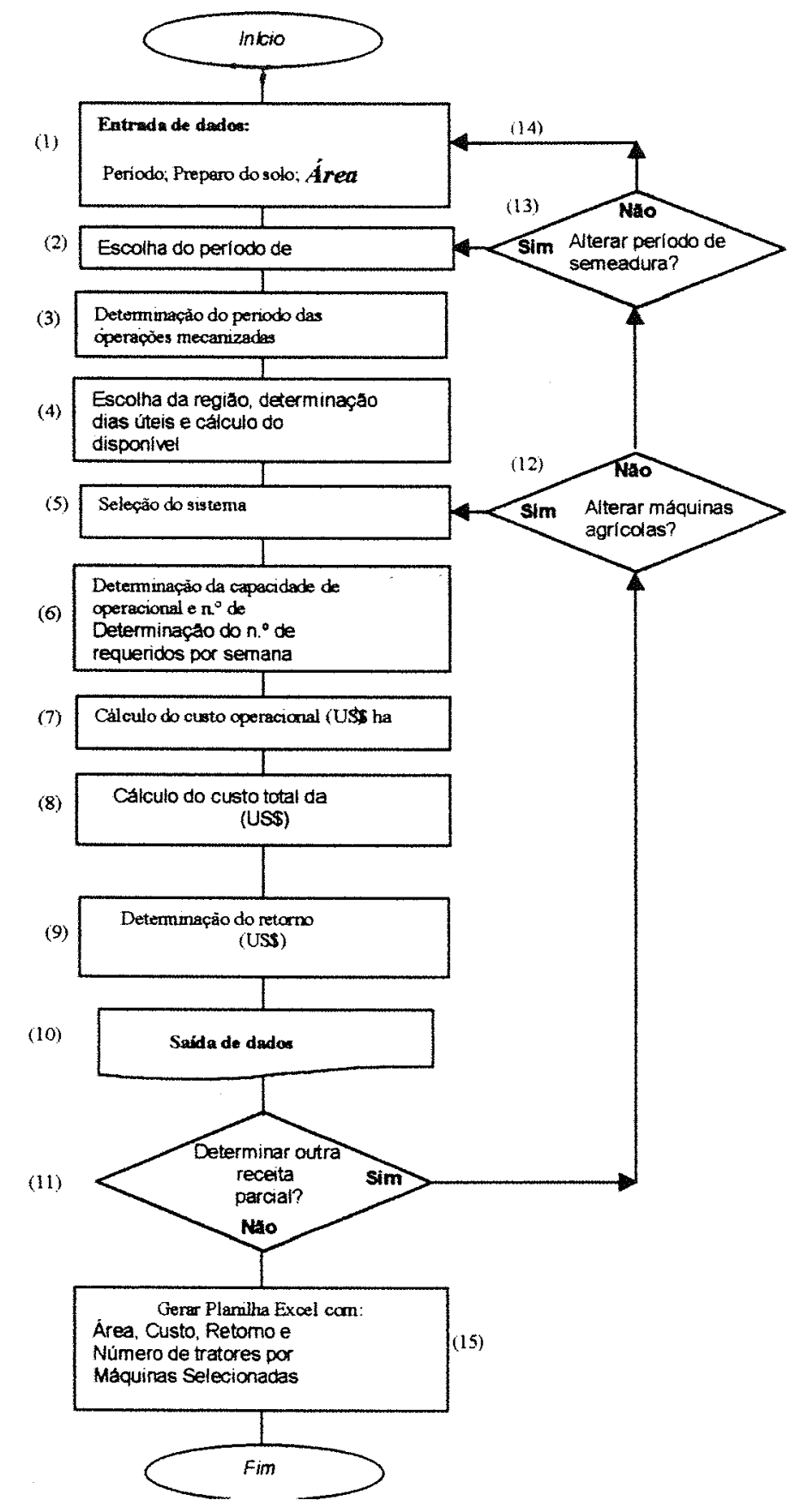

Figura 10. Fluxograma básico do modelo. 
Tabela 9. Prazo para cumprir as operações mecanizadas em relação a época de semeadura.

\begin{tabular}{|c|c|c|}
\hline Operação & & Época indicada \\
\hline Preparo do solo & & Até 10 dias antes do início da semeadura \\
\hline $\begin{array}{c}\text { Aplicação de herbicida em } \\
\text { emergência }\end{array}$ & pré- & Até 3 dias antes do início da semeadura \\
\hline $\begin{array}{c}\text { Aplicação de herbicida em } \\
\text { emergência }\end{array}$ & pós- & De 15 a 25 dias após a semeadura \\
\hline $\begin{array}{c}\text { Aplicação de inseticida } \\
\text { Colheita }\end{array}$ & & $\begin{array}{l}\text { De } 25 \text { a } 90 \text { dias após a semeadura } \\
\text { De } 120 \text { a } 140 \text { dias após a semeadura }\end{array}$ \\
\hline
\end{tabular}

Tabela 10. Máquinas selecionadas de acordo com a faixa de potência, onde: $L T=$ largura de trabalho; e PI = preço inicial.

\begin{tabular}{|c|c|c|c|c|c|c|}
\hline \multirow[b]{3}{*}{ Máquinas } & \multicolumn{6}{|c|}{ Potência $(k w)$} \\
\hline & \multicolumn{2}{|r|}{56} & \multicolumn{2}{|c|}{67} & \multicolumn{2}{|r|}{89} \\
\hline & $\begin{array}{c}\mathrm{LT} \\
(\mathrm{mm})\end{array}$ & $\begin{array}{c}\text { PI } \\
\text { (US\$) }\end{array}$ & $\begin{array}{c}\text { LT } \\
(\mathrm{mm})\end{array}$ & $\begin{array}{c}P I \\
\text { (US\$) }\end{array}$ & $\begin{array}{c}\mathrm{LT} \\
(\mathrm{mm})\end{array}$ & $\begin{array}{c}P I \\
\text { (US\$) }\end{array}$ \\
\hline Trator & - & $19.920,00$ & - & $31.364,00$ & - & $34.000,00$ \\
\hline A rado & 900 & 657,00 & 1350 & 857,00 & 1800 & $4.981,00$ \\
\hline Grade & 2140 & $1.998,00$ & 3310 & $3.036,00$ & 4870 & $5.029,00$ \\
\hline Dist. Calcá rio & 6000 & $4.892,00$ & 14000 & $6.189,00$ & 14000 & $6.189,00$ \\
\hline Pulveriza dor 1 & 9000 & 2.607 .00 & 12000 & $2.600,00$ & 14000 & $3.719,00$ \\
\hline Semeadora & 2900 & $11.714,00$ & 3400 & $12.883,00$ & 5500 & $26.750,00$ \\
\hline Pulverizador 2 & 9000 & $2.607,00$ & 12000 & $2.600,00$ & 14000 & $3.719,00$ \\
\hline
\end{tabular}

Tabela 11. Periodo de semeadura, para definir a pontualidade na operação mecanizada nos cenários estudados.

\begin{tabular}{ccc}
\hline $\begin{array}{c}N^{0} \text { de semanas } \\
\text { de semeadura }\end{array}$ & $\begin{array}{c}\text { Inicio de } \\
\text { semeadura }\end{array}$ & $\begin{array}{c}\text { Fim da } \\
\text { semeadura }\end{array}$ \\
\hline 1 & $17 / 09 / 98$ & $25 / 09 / 98$ \\
2 & $17 / 09 / 98$ & $02 / 10 / 98$ \\
3 & $17 / 09 / 98$ & $09 / 10 / 98$ \\
4 & $17 / 09 / 98$ & $16 / 10 / 98$ \\
5 & $17 / 09 / 98$ & $24 / 10 / 98$ \\
6 & $17 / 09 / 98$ & $31 / 10 / 98$ \\
7 & $17 / 09 / 98$ & $07 / 11 / 98$ \\
8 & $17 / 09 / 98$ & $13 / 11 / 98$ \\
9 & $17 / 09 / 98$ & $21 / 11 / 98$ \\
10 & $17 / 09 / 98$ & $28 / 11 / 98$ \\
11 & $17 / 09 / 98$ & $05 / 12 / 98$ \\
12 & $17 / 09 / 98$ & $17 / 12 / 98$ \\
\hline
\end{tabular}

\footnotetext{
${ }^{2}$ BASF - O Brasil já collhe o futuro (folheto)
} 
As simulações (cenários) foram efetuadas utilizando-se o programa de maneira interativa, realizando-se a variação da data de semeadura, área plantada e faixa de potência, em um total de 108; o diagrama básico das simulações é apresentado na Figura 11.

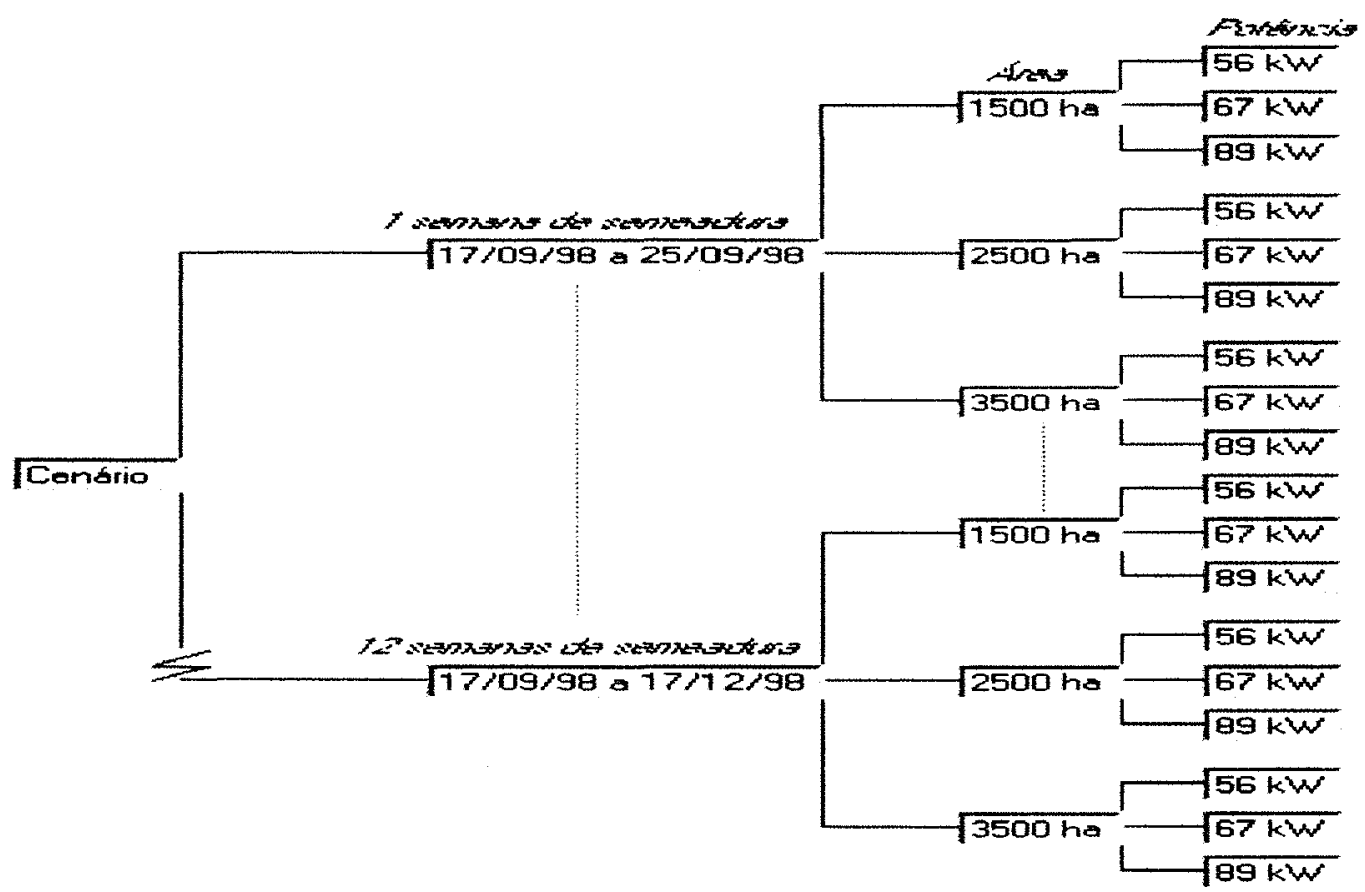

Figura 11. Cenários desenvolvidos para aplicação do modelo, considerando a pontualidade.

\subsection{RESULTADOS E DISCUSSÃO}

\subsubsection{Número de Máquinas}

O número de conjuntos mecanizados variou de acordo com o planejamento, e principalmente devido ao período de semeadura determinado. Para a área de 1500 ha, o número de tratores e a distribuição da frota para o periodo de 1 a 12 semanas é apresentado na Figura 12. Como a época das demais operaçōes mecanizadas varia de acordo com a época de semeadura, quanto maior o periodo, melhor a distribuição da frota mecanizada. 


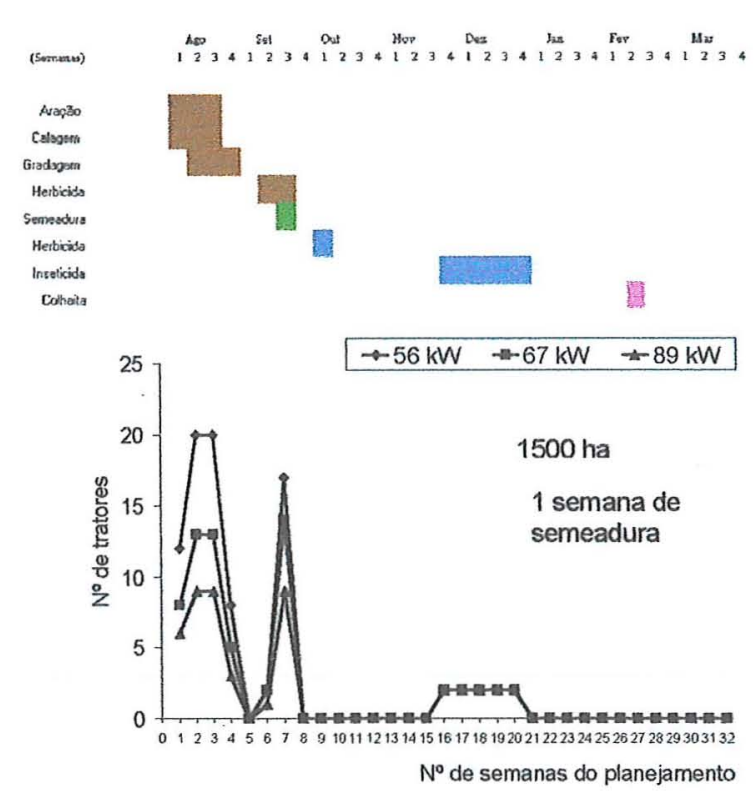

(a)
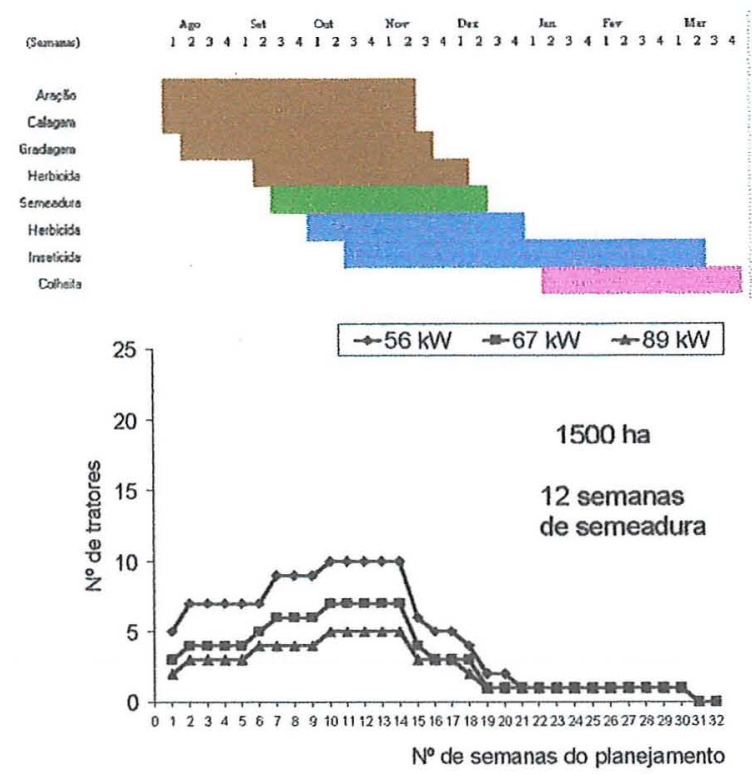

(b)

Figura 12. Distribuição dos conjuntos mecanizados, de acordo com o número de semanas de semeadura, para a área de 1500 ha em: a) uma semana de semeadura; b) doze semanas de semeadura.

Com a realização da semeadura em apenas 1 semana, o número de conjuntos mecanizados para a realização das operações foi elevado, com épocas em que as operações somavam 20 tratores. Esse valor é o dobro comparado a semeadura realizada no período de 12 semanas disponíveis, com exigência máxima de 10 tratores. A diminuição do número de conjuntos faz com que se eleve o número de horas de uso das máquinas, evitando a ociosidade.

Os tratores de maior faixa de potência, no caso $89 \mathrm{~kW}$, apresentaram o menor número de conjuntos, nas duas situações, devido ao aumento da largura de trabalho dos implementos correspondentes.

\subsubsection{Retorno Econômico}

O retorno médio econômico, calculado pela Equação 3 , foi semelhante para tamanho de área e faixa de potência, variando apenas entre as semanas (Figura 13), com destaque para valores mínimo e máximo obtidos pelo modelo, em comparação ao 
apresentado pela FNP (1998) de US\$ ha ${ }^{-1} 431,45$ para rendimento médio de $2000 \mathrm{~kg} \mathrm{ha}^{-1}$, no preparo convencional do solo. O máximo valor obtido no modelo foi de US $\$ \mathrm{ha}^{-1} 510,00$ e o mínimo de US $\$$ ha $^{-1} 300,00$, representando $18 \%$ e $-30 \%$ em relação ao obtido em literatura. A semeadura realizada em 10 semanas (entre 17/09/98 a 28/11/98) apresentou o maior retomo médio econômico.

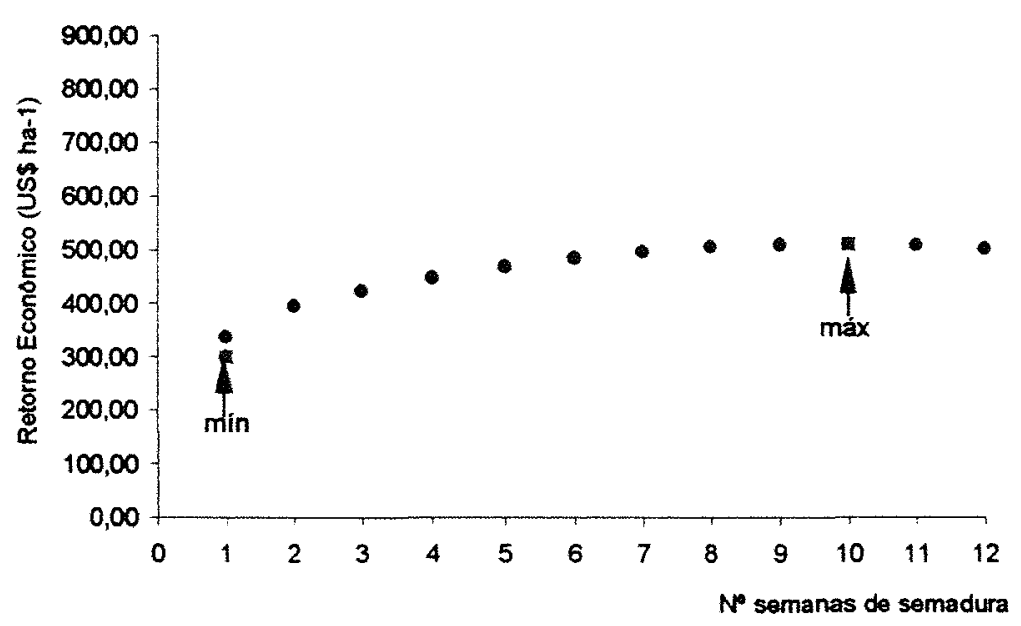

Figura 13. Distribuição do retorno médio econômico em diferentes épocas de semeadura de todos os cenários estudados, destacando-se o mínimo e o máximo valor obtido.

\subsubsection{Custo de Mecanização}

Na comparação do custo de mecanização por tamanho de área, observa-se que os custos diminuem a medida que aumenta o número de semanas trabalhadas (Figura 14). No que se refere às três faixas de potência, a ordem decrescente de custos foi a mesma: de 56 $\mathrm{kW}$ para $89 \mathrm{~kW}$, apesar da diferença crescente entre os preços iniciais das máquinas selecionadas. A área de 3500 ha apresentou custos muito superiores (US\$ ha ${ }^{-1} 188,00$ ) comparados a 1500 ha (US $\$$ ha $^{-1} 85,00$ ), com diferença de $45 \%$ entre os menores custos de mecanização obtidos em 12 semanas de semeadura para a faixa de potência de $89 \mathrm{~kW}$, devido ao número de conjuntos requeridos.

Os custos de mecanização encontrados pelo modelo, em grande parte, foram muitos superiores ao encontrado em literatura (US\$ ha ${ }^{-1} 149,30$ ). Isso porque para a base de 
cálculo do custo de mecanização normalmente emprega-se 1000 horas de utilização anual de tratores e 500 horas para implementos e no modelo, as horas de trabalho variam de acordo com o periodo de planejamento para o manejo da cultura da soja.
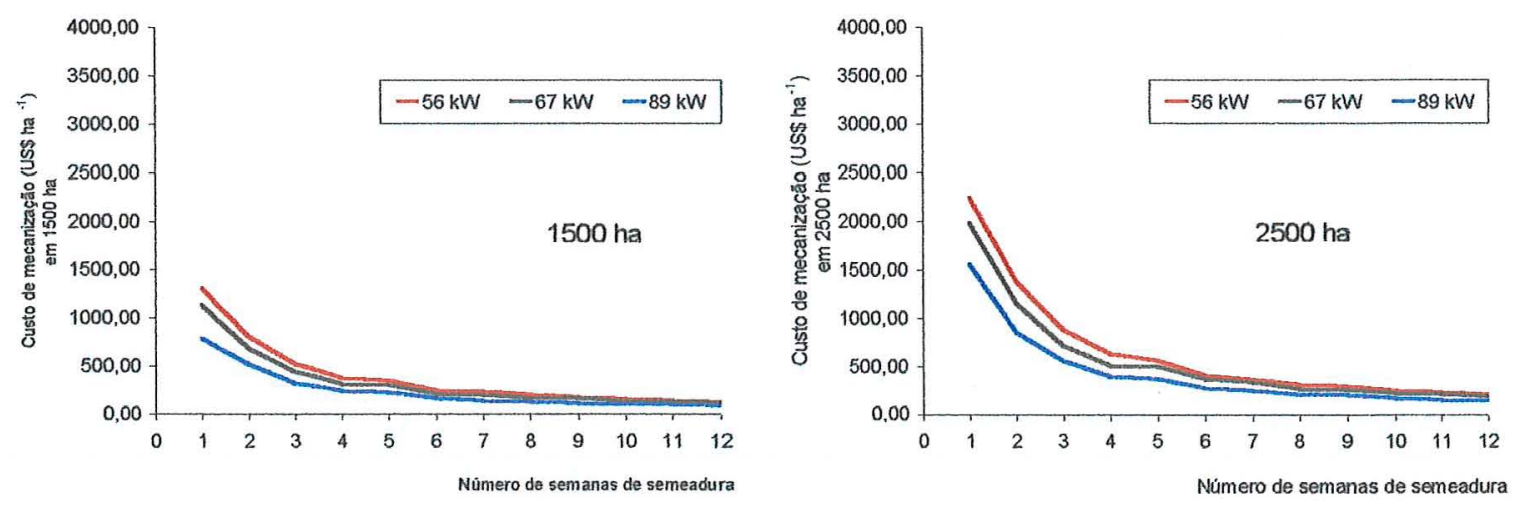

(a)

(b)

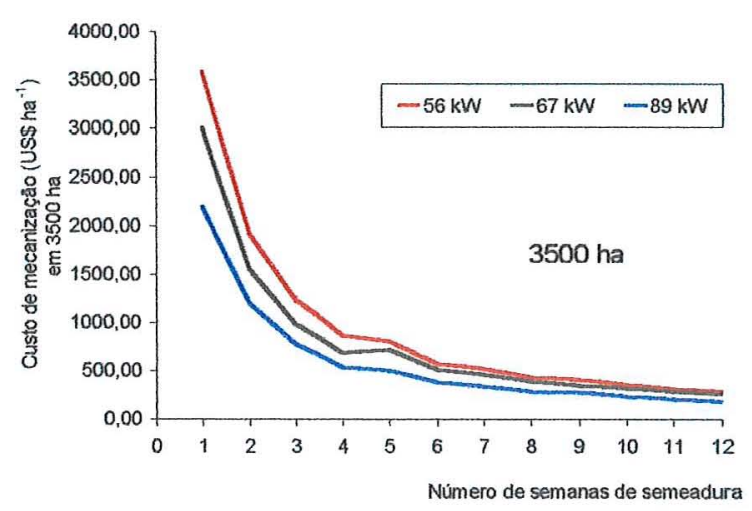

(c)

Figura 14. Custo de mecanização (US\$ ha ${ }^{-1}$ ) de acordo com o número de semanas de semeadura em três tamanhos de área: (a) 1500 ha; (b) 2500 ha; (c) 3500 ha.

\subsubsection{Receita Parcial}

A maior receita parcial obtida ocorreu na semeadura realizada no intervalo de 12 semanas (entre 17/09/98 a 17/12/98) para os três tamanhos de área (Figura 15) com valores de US $\$$ ha-1 417,00 , US $\$$ ha ${ }^{-1} 361,00$ e US $\$$ ha $^{-1} 313,00$ para 1500 ha, 2500 ha e 3500 ha, respectivamente, na faixa de potência de $89 \mathrm{~kW}$. Essas diferenças representam $46 \%, 27 \% \mathrm{e}$ 
$10 \%$ superiores ao valor de receita parcial calculado a partir dados fornecidos pela FNP (1998) de US $\$ \mathrm{ha}^{-1} 285,15$, para rendimento de $2000 \mathrm{~kg} \mathrm{ha}^{-1}$.
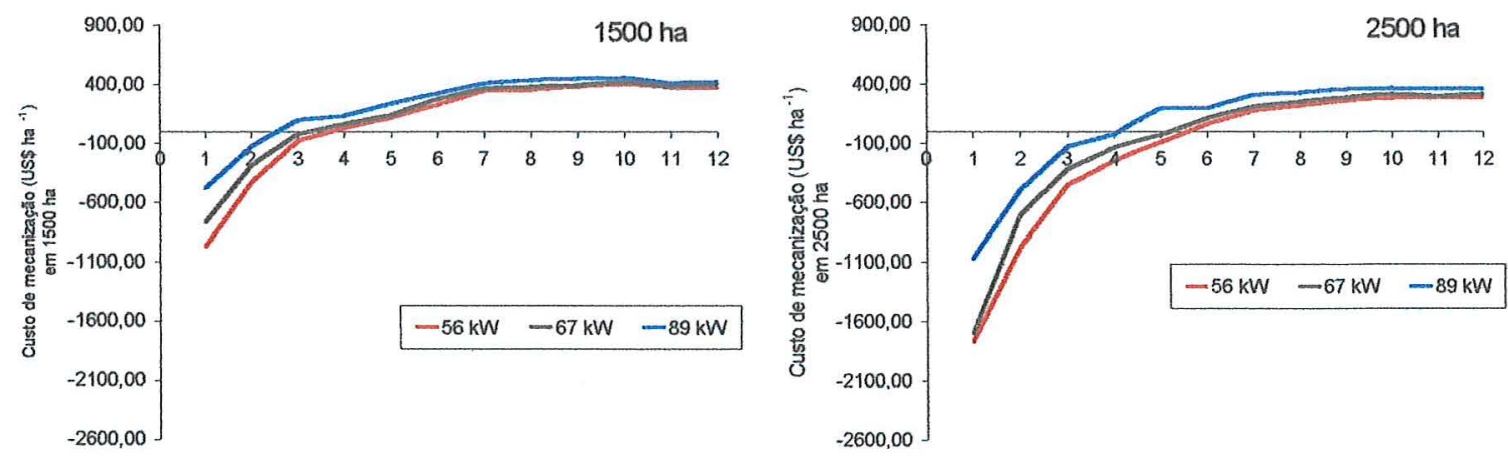

Número de semanas de semeadura

(a)

(b)

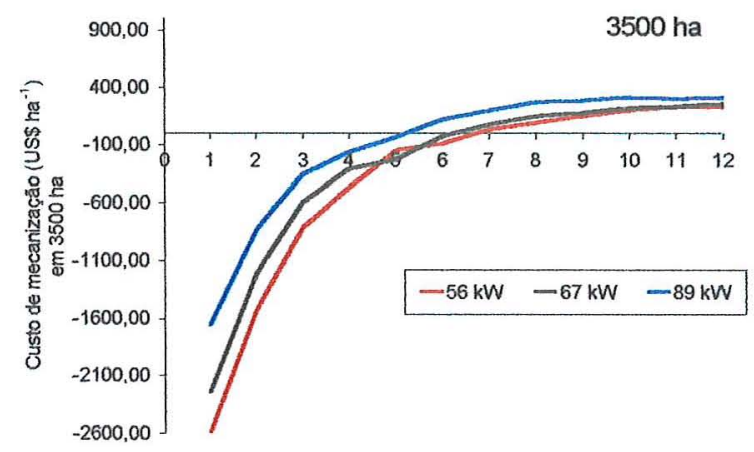

Número de semanas de semeadura

(c)

Figura 15. Receita Parcial (US\$ ha ${ }^{-1}$ ) de acordo com o número de semanas de semeadura em três tamanhos de área: (a) 1500 ha; (b) 2500 ha; (c) 3500 ha.

Apesar do retorno econômico apresentar os melhores resultados no período de 10 semanas de semeadura, a melhor receita parcial, para três tamanhos de área na faixa de potência de $89 \mathrm{~kW}$ foi no período de 12 semanas de semeadura. Independente do rendimento da cultura, quanto maior o número de horas de uso do maquinário agrícolas, menores os custos de mecanização devido a menor ociosidade dessas máquinas, aumentando a receita obtida na produção da cultura da soja. $\mathrm{Na}$ Tabela 12, o resumo dos resultados obtidos para 12 semanas de semeadura comparada aos valores divulgados pela FNP (1998), que representa a média nacional. 
O custo de mecanização para área de 1500 ha demonstrou ser inferior ao da literatura em todas as faixas de potência, ao contrário do que ocorreu em 3500 ha. Em 2500 ha, somente a faixa de potência de $89 \mathrm{~kW}$ apresentou-se inferior. Na receita parcial, apenas as áreas de 3500 ha nas faixas de potência de $56 \mathrm{~kW}$ e $67 \mathrm{~kW}$ apresentaram valores inferiores ao valor obtido em literatura.

Tabela 12. Custo de mecanização (US\$ ha ${ }^{-1}$ ) e Receita Parcial (US\$ ha ${ }^{-1}$ ) para 12 semanas de semeadura.

\begin{tabular}{ccccccccc}
\hline & \multicolumn{3}{c}{ Custo de mecanizacáo (US\$ ha ${ }^{-1}$ ) } & \multicolumn{3}{c}{ Receita Parcial (US\$ ha ${ }^{-1}$ ) } \\
\cline { 2 - 9 } Area (ha) & Literatura & $56 \mathrm{~kW}^{*}$ & $67 \mathrm{~kW}^{*}$ & $89 \mathrm{~kW}^{*}$ & Literatura & $56 \mathrm{~kW}^{*}$ & $67 \mathrm{~kW}^{*}$ & $89 \mathrm{~kW}^{*}$ \\
\hline 1500 & 149,30 & 126,00 & 109,00 & 85,00 & 285,15 & 376,00 & 393,00 & 417,00 \\
2500 & 149,30 & 206,00 & 184,00 & 140,00 & 285,15 & 295,00 & 317,00 & 361,00 \\
3500 & 149,30 & 287,00 & 259,00 & 188,00 & 285,15 & 214,00 & 242,00 & 313,00 \\
\hline
\end{tabular}

*Faixa de potência

\subsection{CONCLUSÕES}

O número de máquinas diminuiu com o aumento da época de semeadura e faixa de potência dos tratores.

O retorno médio econômico, pela metodologia adotada, foi diferente entre épocas de semeadura e não variou com tamanho de área e faixa de potência.

O custo de mecanização diminui com o aumento da época de semeadura devido ao maior número de horas de uso anual do maquinário agrícola, ocorrendo aumento da receita parcial. 


\section{CONCLUSÕES GERAIS}

O modelo apresentou ser adequado para a consideração do custo indireto na operação de semeadura da soja. Referente às etapas do processo, conclui-se que:

Houve resposta de rendimento do cultivar $I A C 17 \mathrm{em}$ relação às épocas de semeadura estudadas. A equação obtida através de análise estatistica foi apropriada para uso no planejamento das atividades agricolas e determinar a pontualidade na semeadura;

O modelo de seleção de máquinas agrícolas correspondentes à produção da soja incluiu a equação de rendimento para caracterizar a pontualidade na semeadura. Através da validação, a rotina e os resultados obtidos foram adequados às situações estudadas;

A utilização do modelo para a cultura da soja demonstrou que existe diferença no custo de mecanização e na receita obtida dependendo do periodo de semeadura. Apesar da cultura da soja apresentar época ideal, considerada como a que proporciona o maior rendimento, o prolongamento desse periodo, visando obter menor número de máquinas e maior número de horas de uso anual, foi fator determinante para diminuição do custo de mecanização e aumento da receita parcial, dentro das condições estudadas. 


\section{ANEXO A}

Formulários do Programa

\section{Modelo Empírico na Seleção de} Máquinas Agrícolas na Cultura da Soja Considerando a Pontualidade na Semeadura

Nome: Crishe Mombina Veiga

Orienador Dr. Marcas Milan

Projeto financiado pela FAPESP

Este modelo laz parte da disserlaçầo apresentada para a obtenção do tílulo de Mestre em Máquinas Agrícolas. Escola Superior de Agricultura "Luiz de Queiroz"

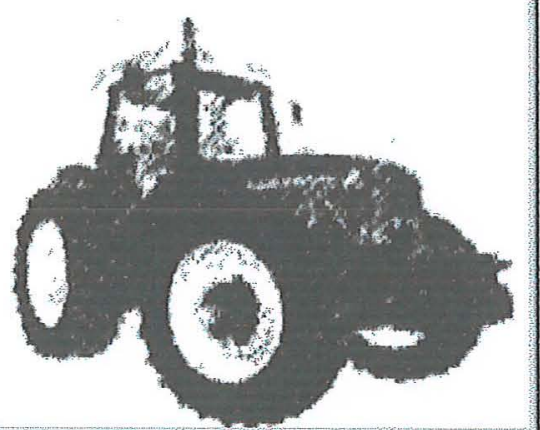

Formulário 1. Apresentação do modelo 


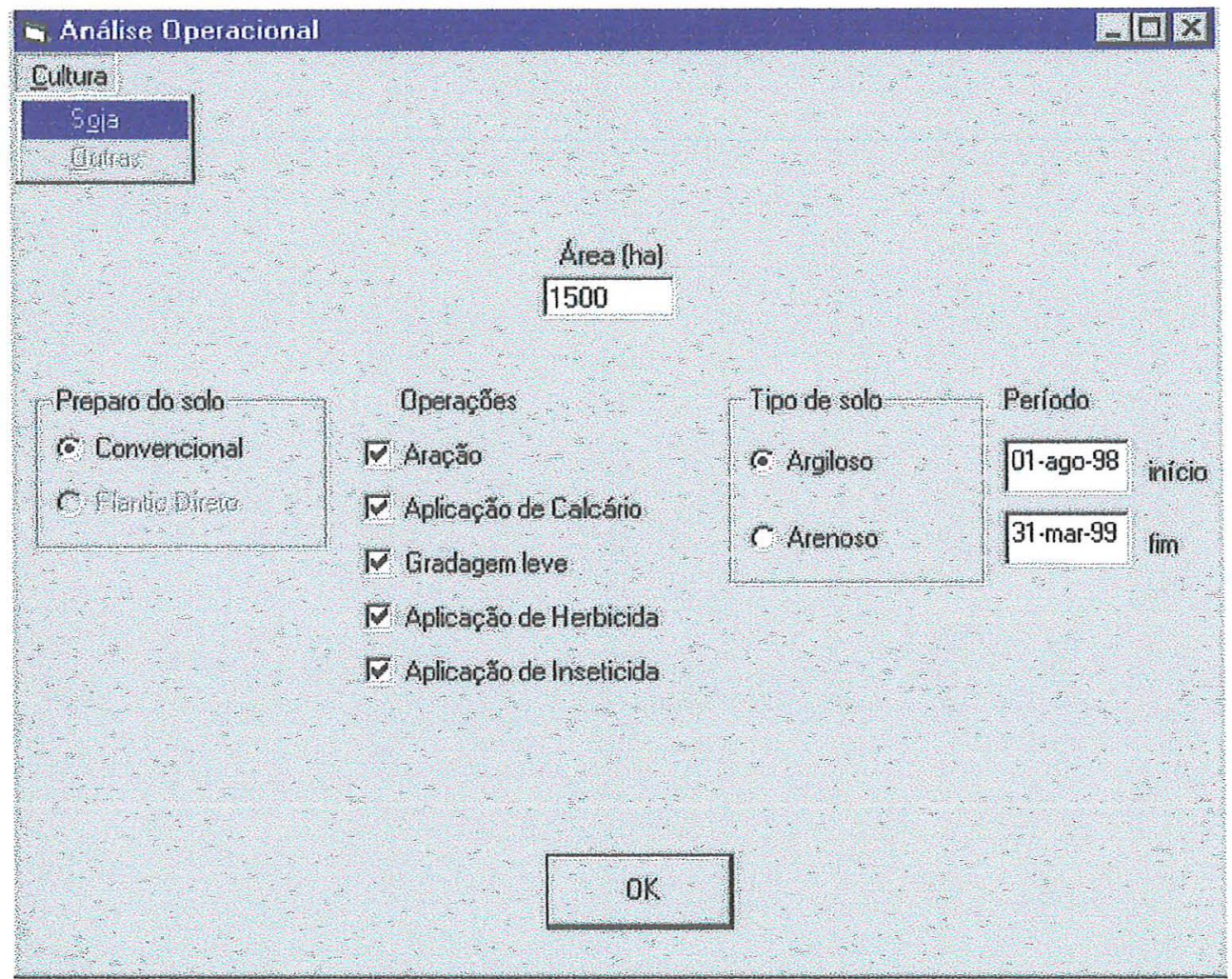

Formulário 2. Escolha do tamanho de área, período do planejamento e preparo do solo 


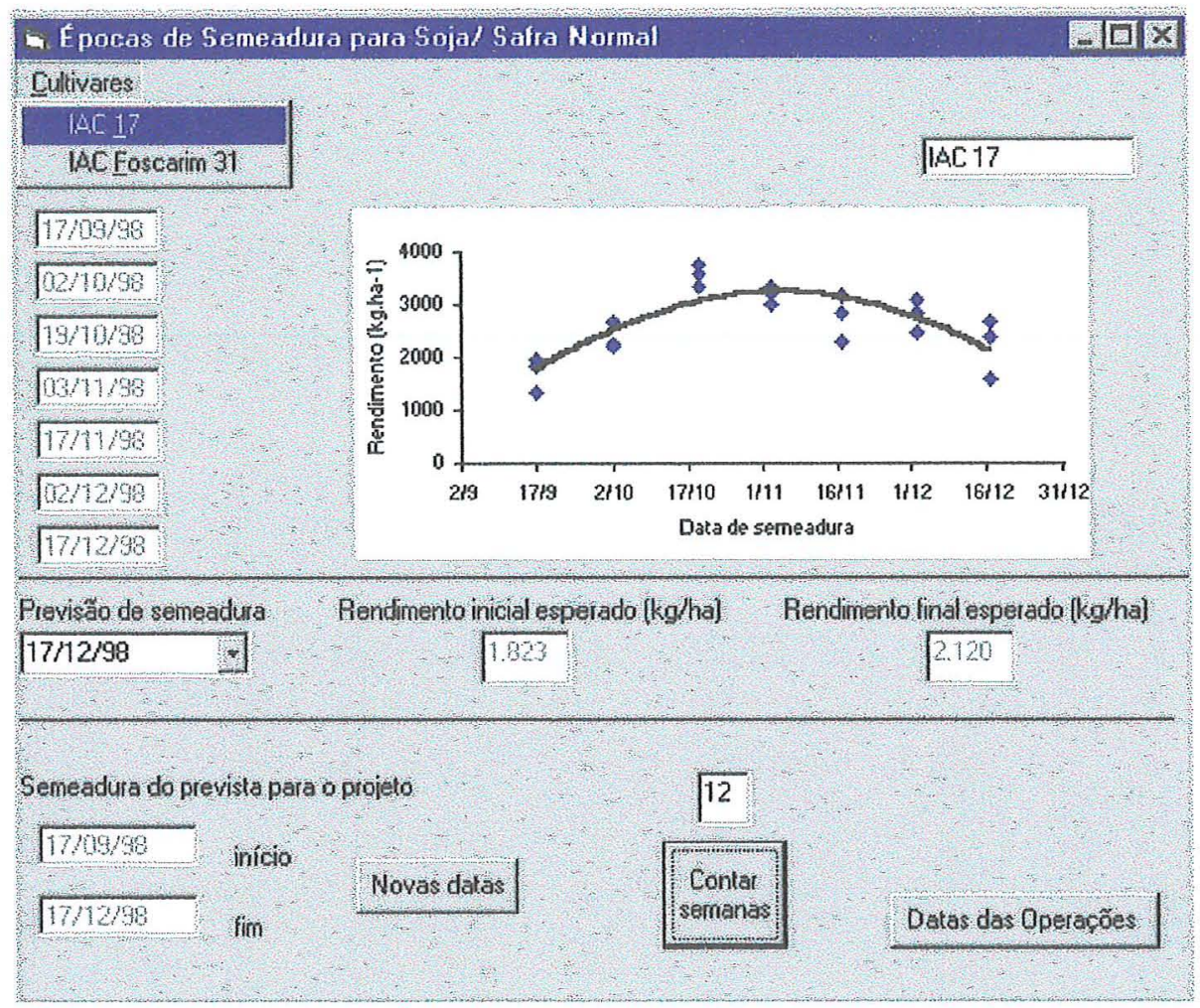

Formulário 3. Determinação de época de semeadura e estimativa de rendimento da cultura da soja 


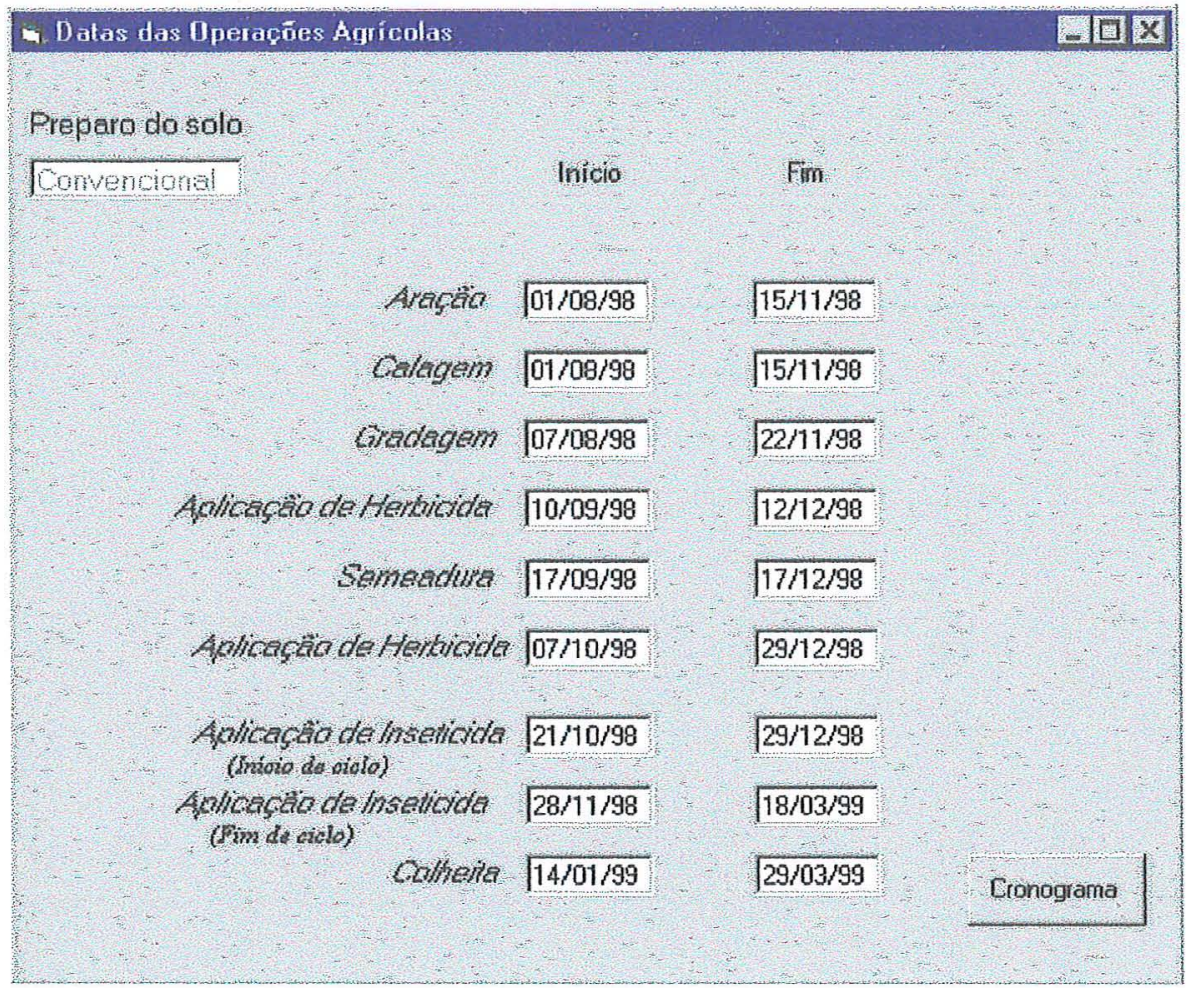

Formulário 4. Datas das operações mecanizadas 


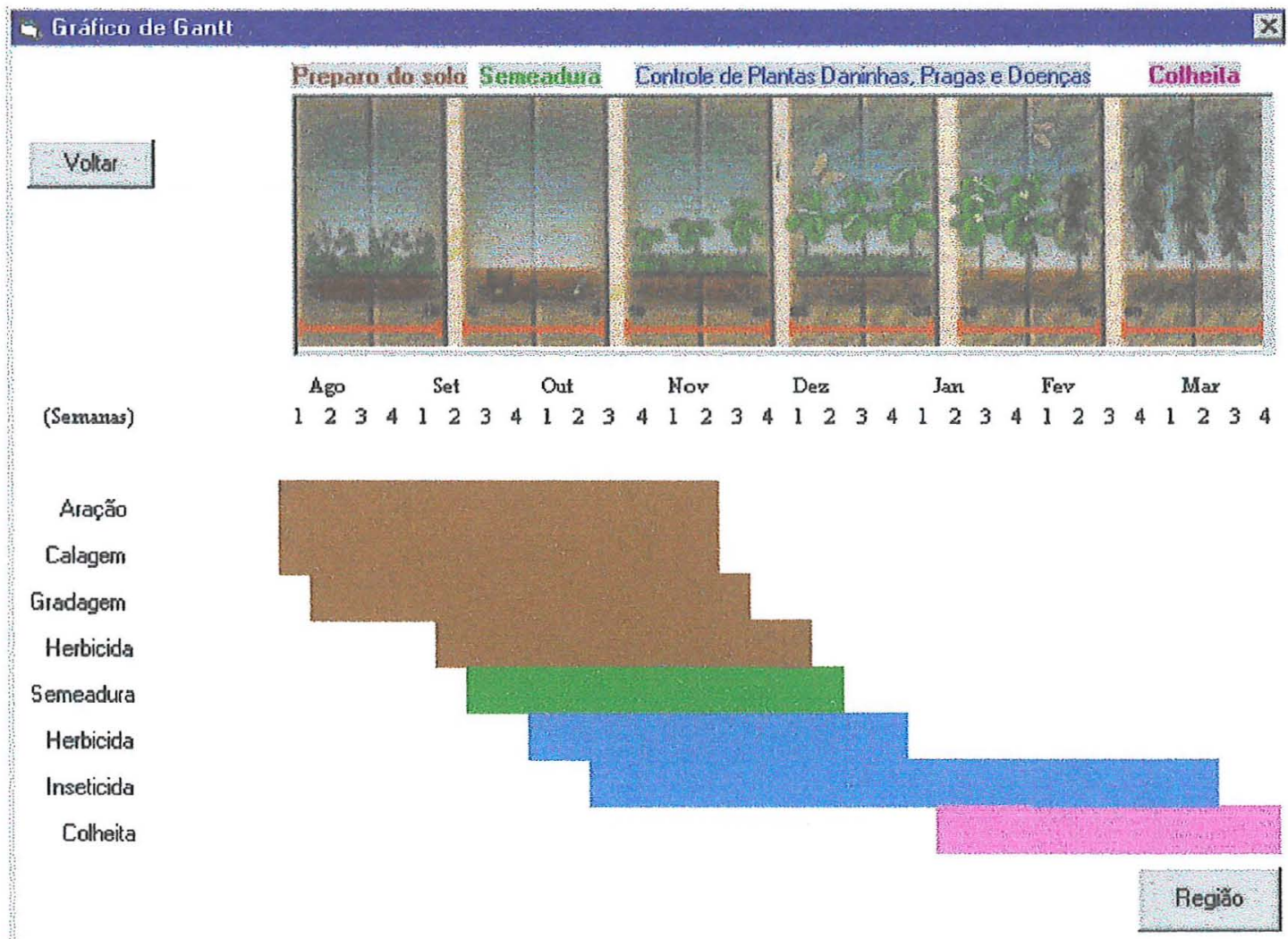

Formulário 5. Gráfico de Gantt 


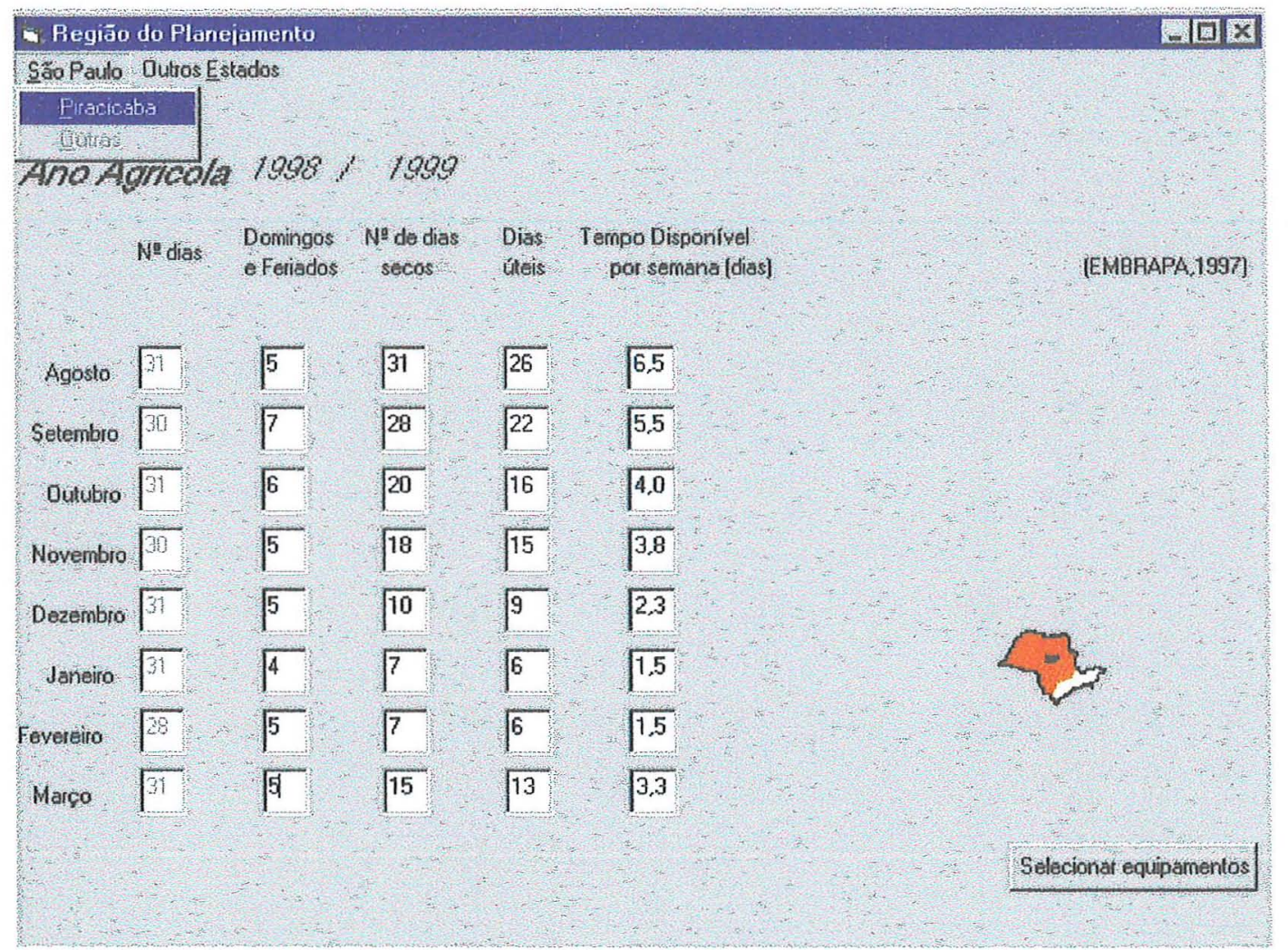

Formulário 6. Escolha da região; determinação dos dias agronomicamente úteis; determinação do tempo disponivel 


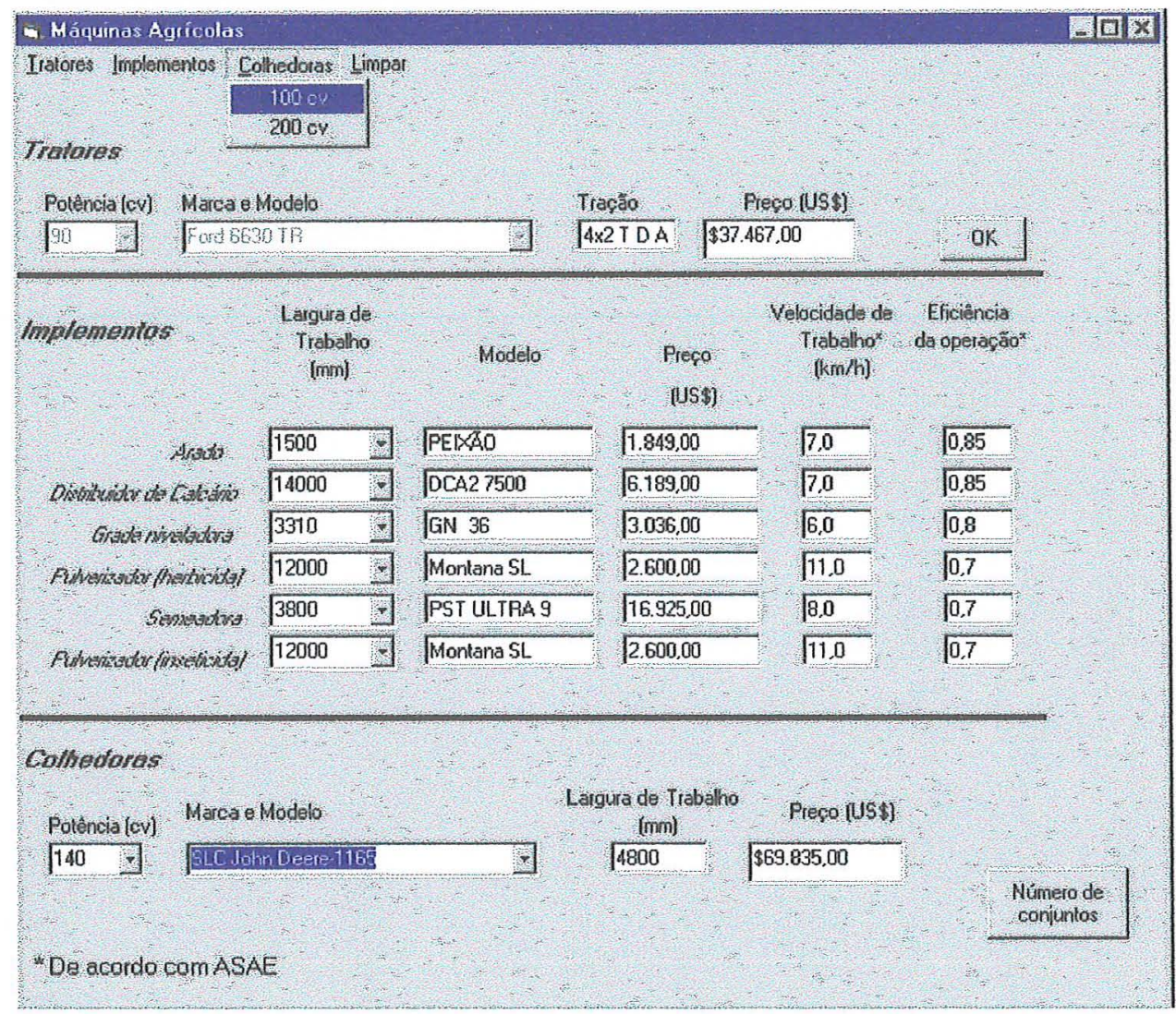

Formulário 7. Escolha das máquinas, de acordo com as suas características 


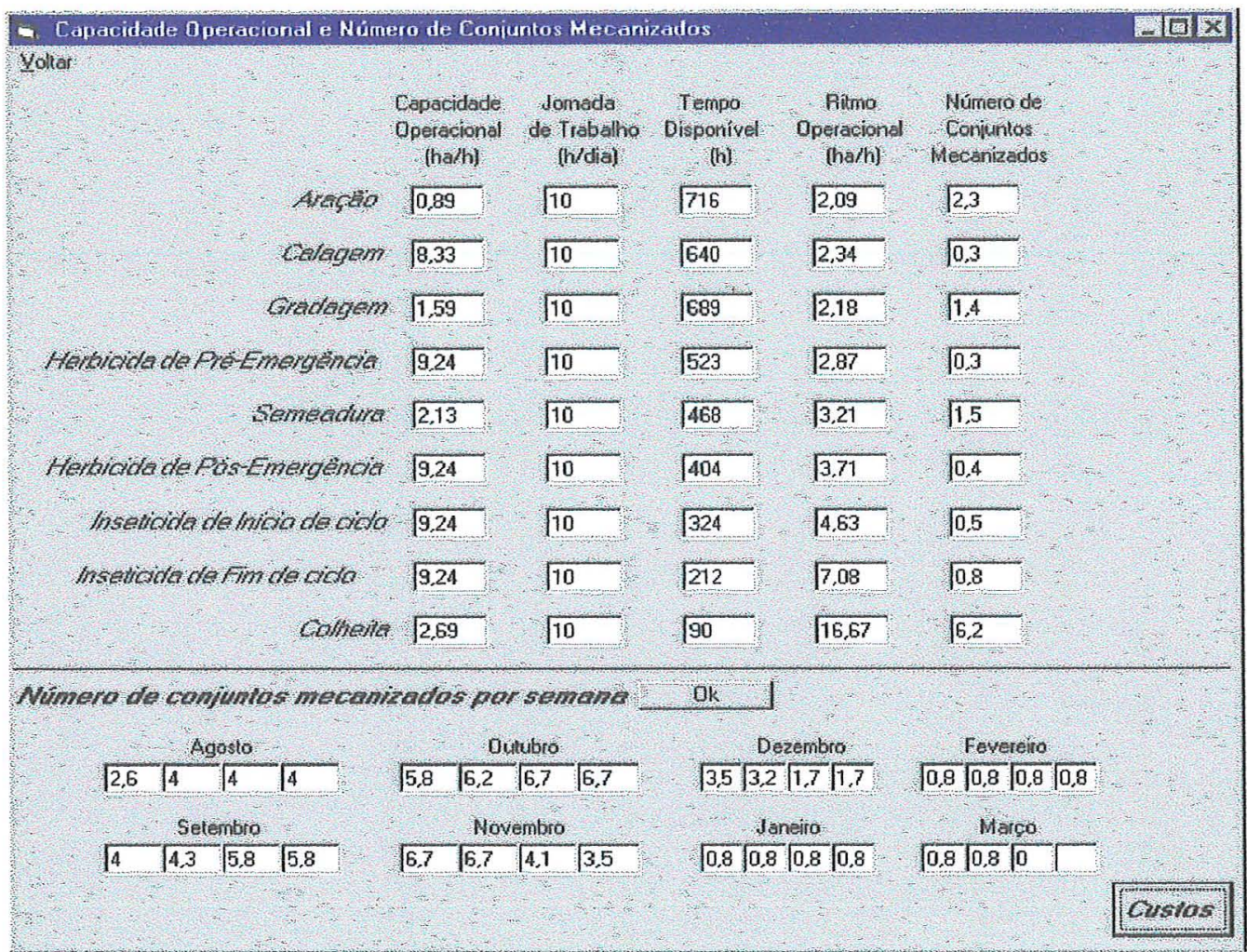

Formulário 8. Determinação da capacidade operacional; escolha da jornada de trabalho; determinação do número de conjuntos mecanizados e colhedoras 


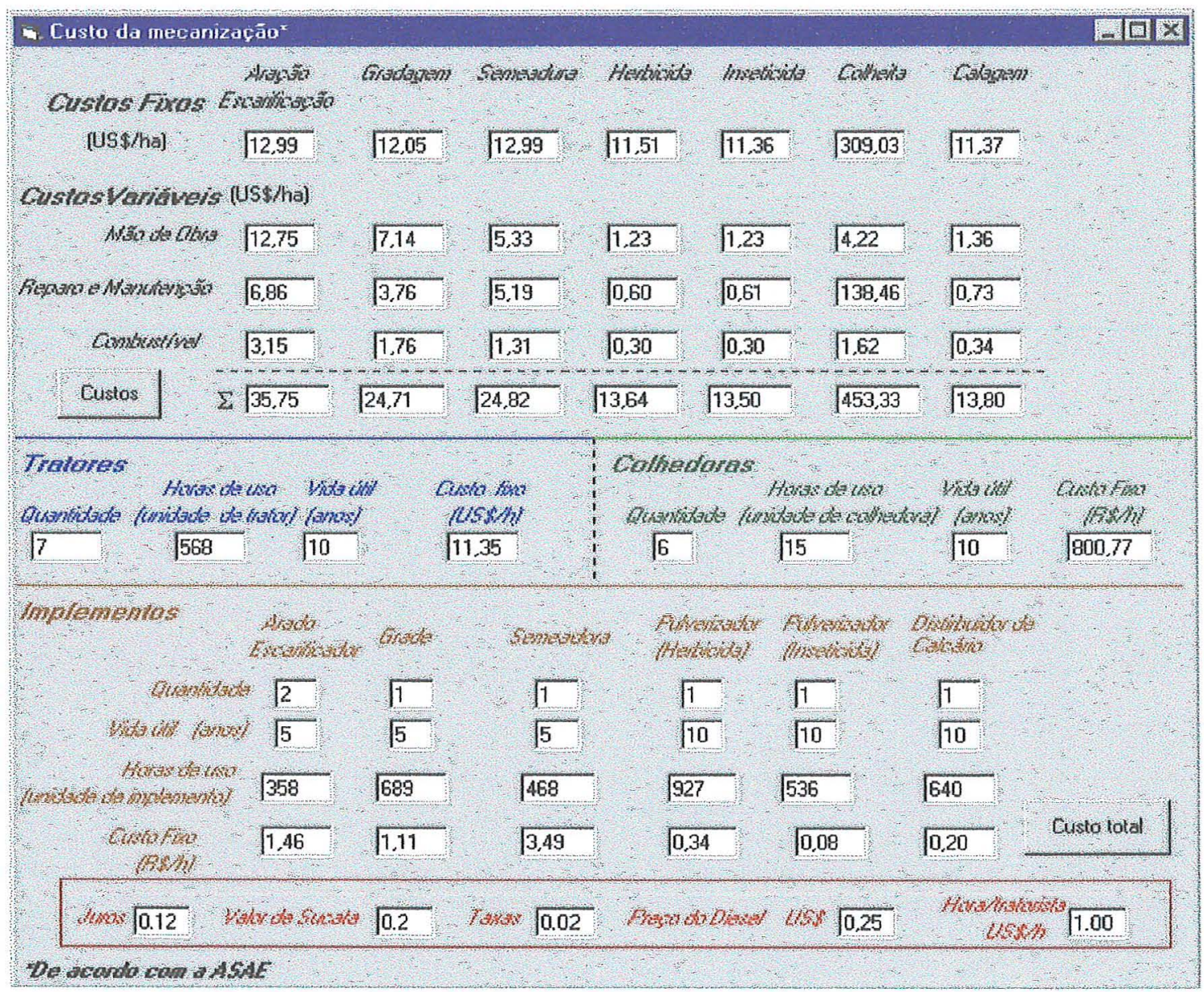

Formulário 9. Determinação dos custos operacionais de acordo com as horas de trabalho de cada conjunto mecanizado e colhedoras 


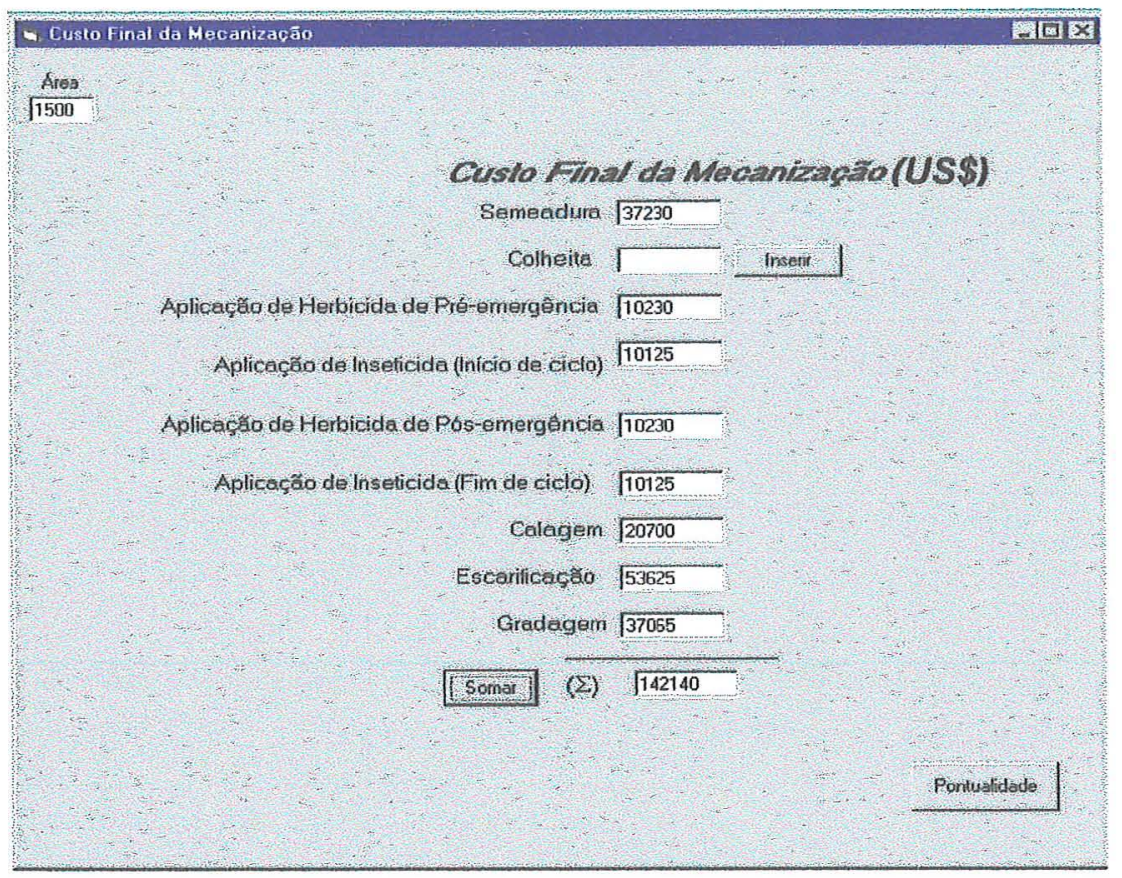

Formulário 10. Determinação do custo final de mecanização, sem a colheita, de acordo com o tamanho de área

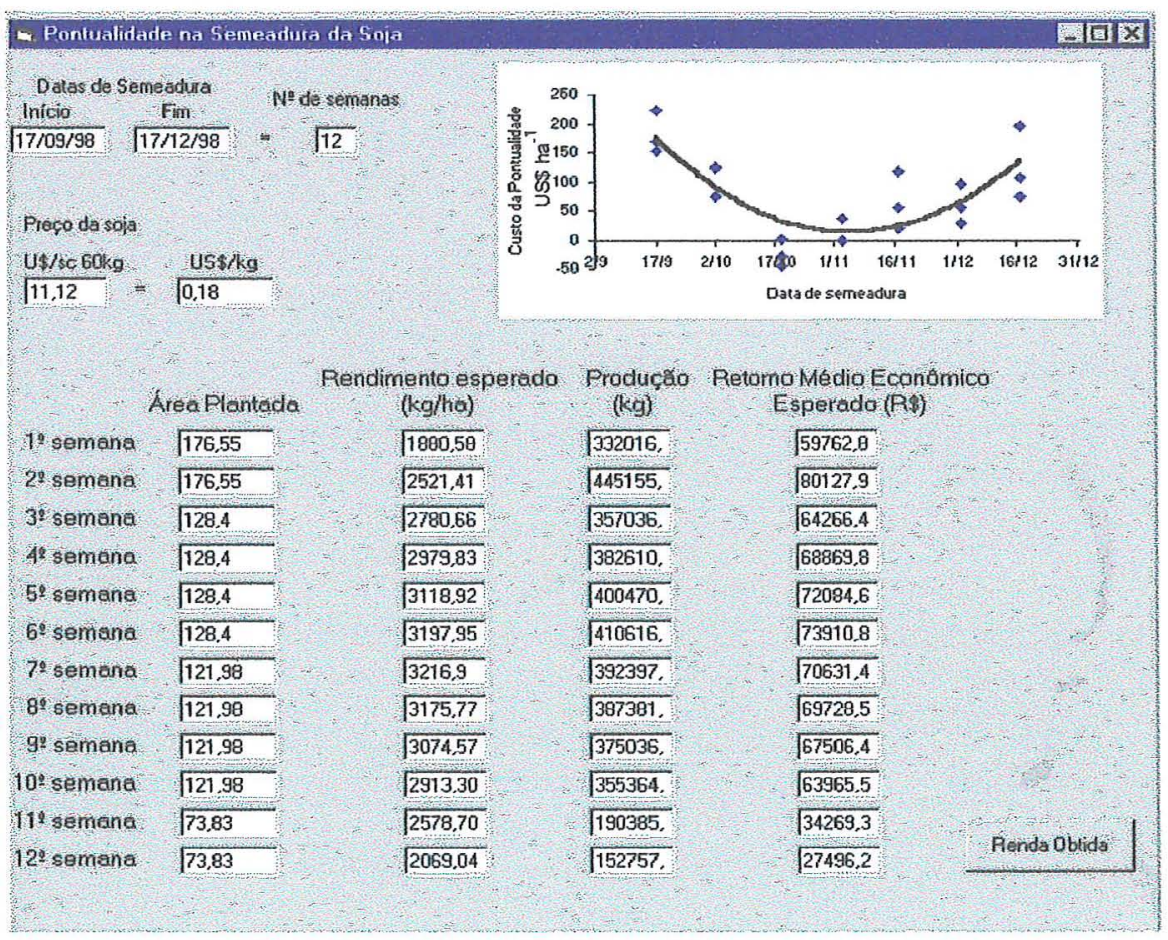

Formulário 11. Determinação da pontualidade de acordo com a metodologia adotada 


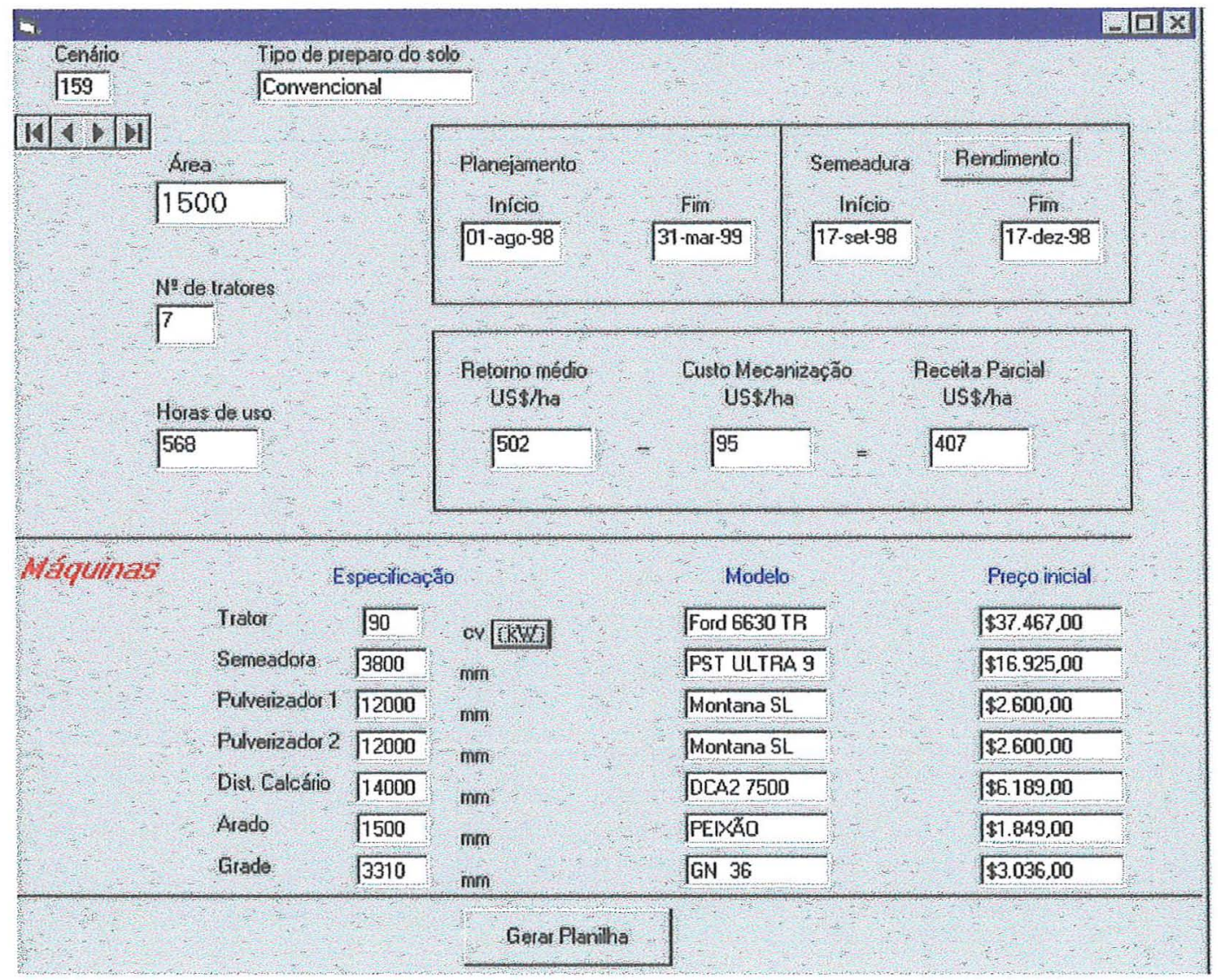

Formulário 12. Cenários estudados 


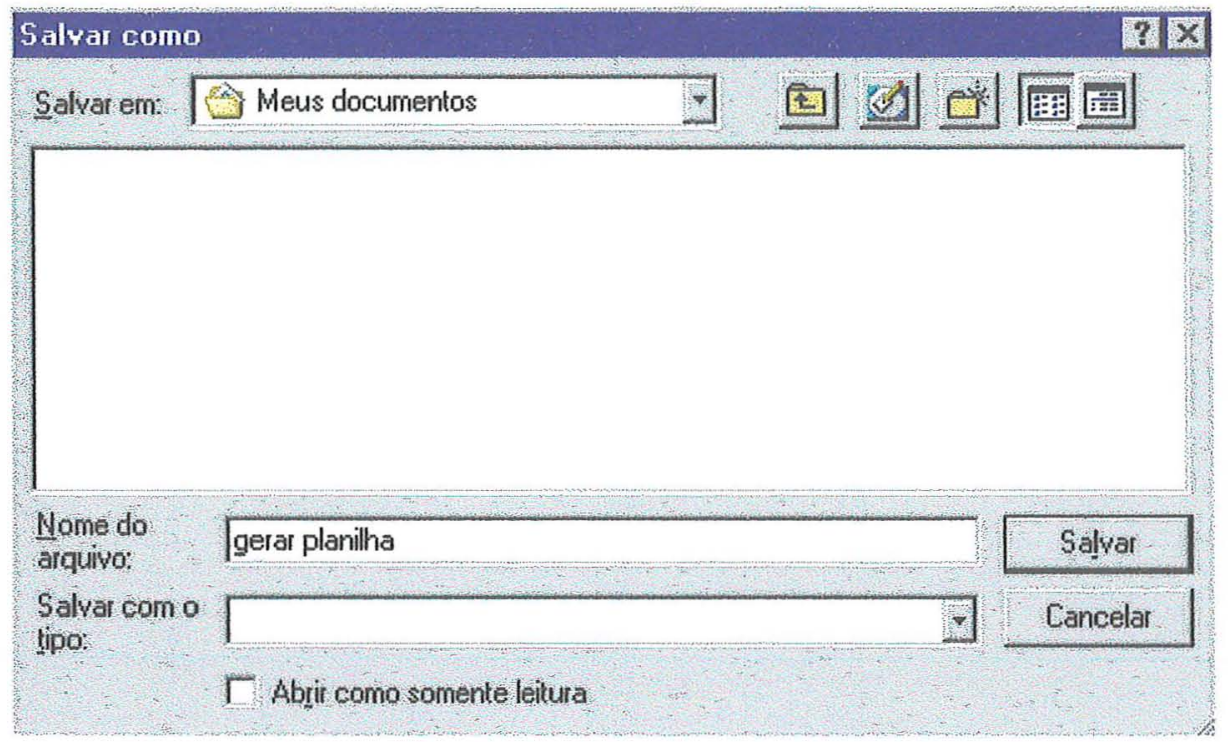

Formulário 13. Arquivo dos cenários estudados em MS EXCEL

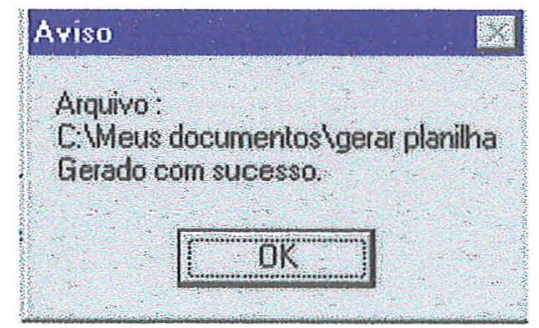

Formulário 14. Obtenção do arquivo em MS EXCEL 


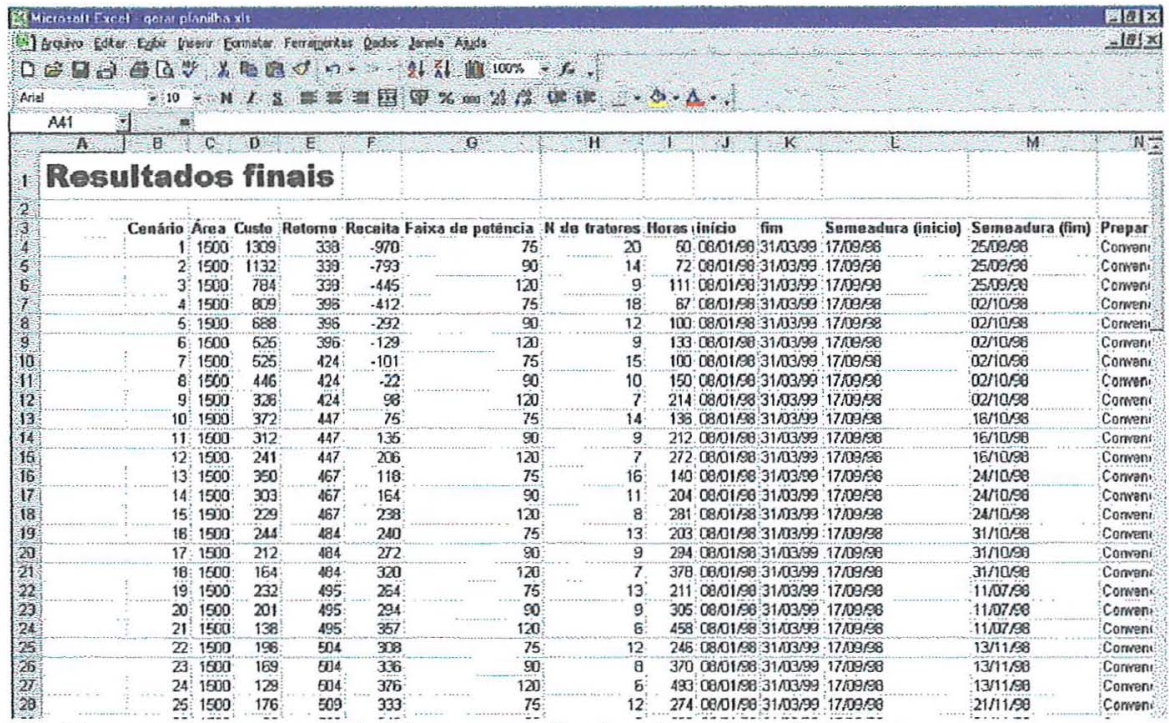

Planilha 1. Resultados econômicos; período de planejamento e semeadura; preparo de solo nos cenários estudados

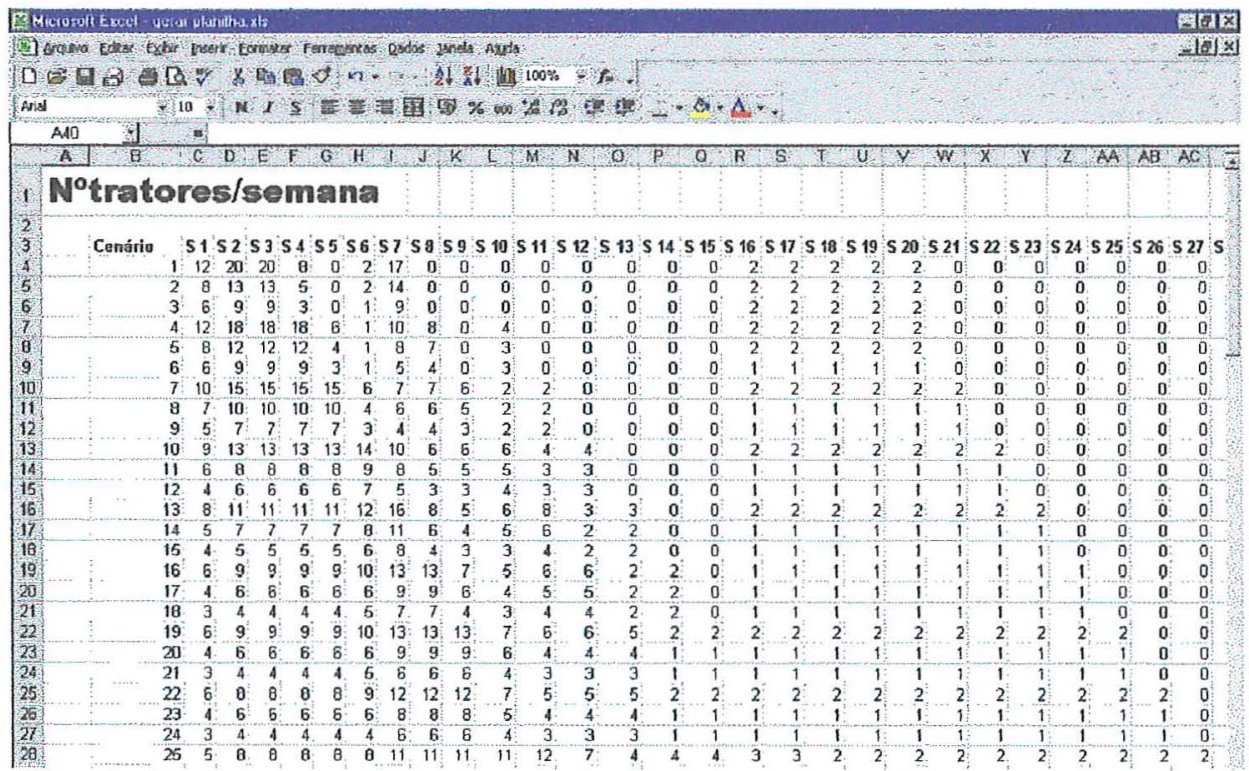

Planilha 2. Número de tratores por semana de planejamento, em cada cenário estudado 


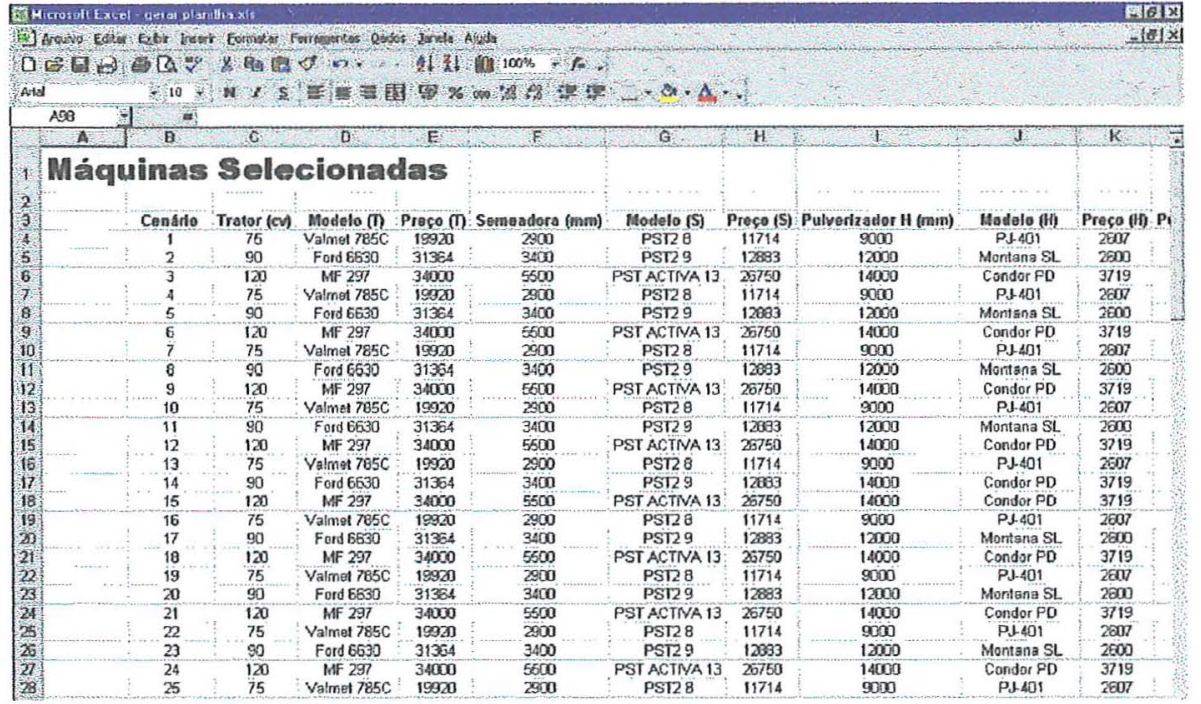

Planilha 3. Máquinas selecionadas em cada cenário estudado 
ANEXO B

\section{Parte da rotina do modelo em MS Visual Basic 6.0}

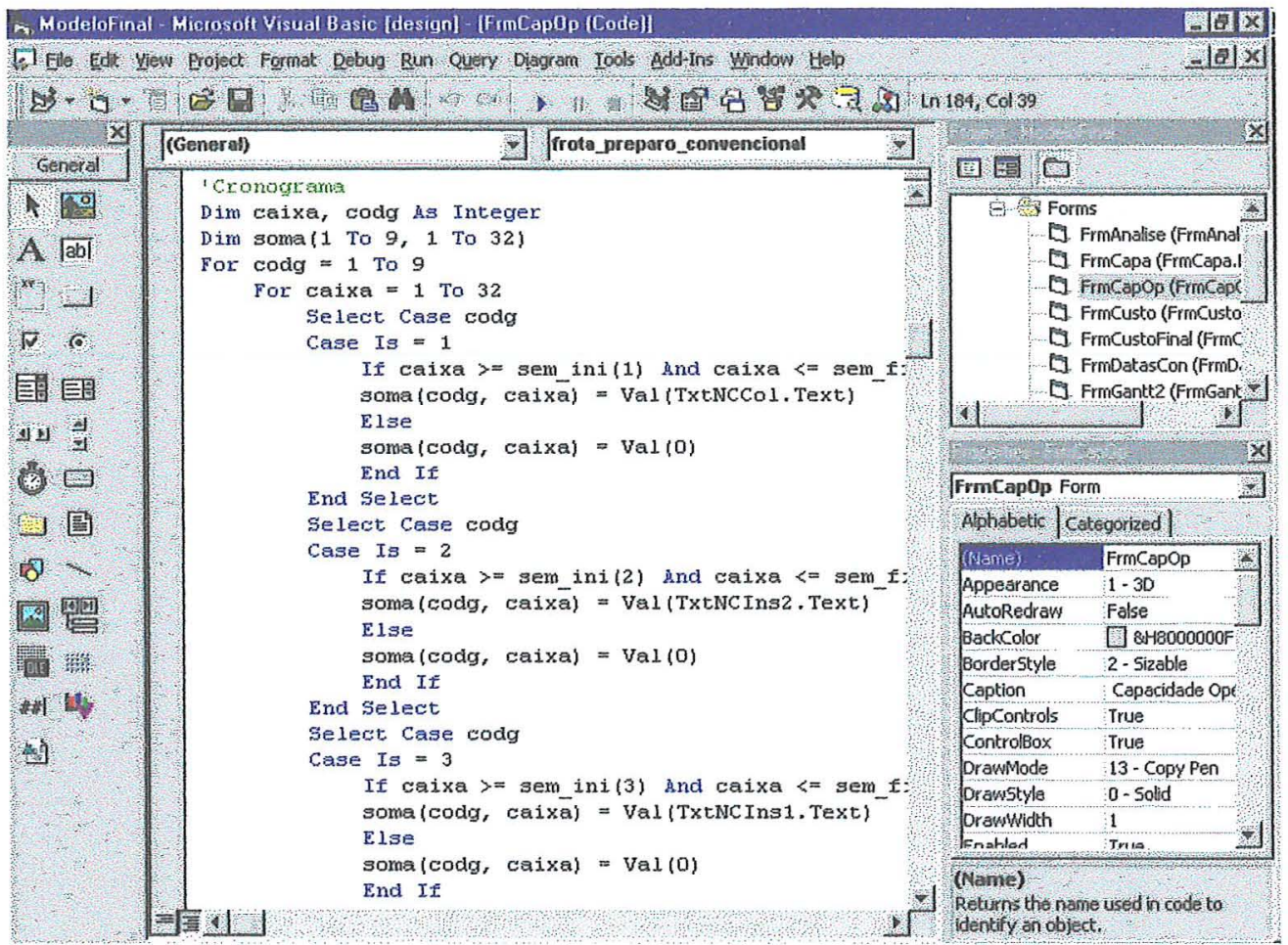




\section{REFERÊNCIAS BIBLIOGRÁFICAS}

ADEMOSUN, O.C. Establishment of a multi-crop production system with minimum fluctuation in tractor and man-hour requirements. Agricultural Mechanization in Asia, Africa and Latin America, v 22, n. 2, p. 35-38, 1991.

AMERICAN SOCIETY OF AGRICULTURAL ENGINEERS. Agricultural engineers yearbook - 1996. St. Joseph, 1996. p. ????: Agricultural management data ASAE.EP496.2 MAR94

AUDSLEY, E.; DUMONT, S.; BOYCE, D.S. An economic comparison of methods of cultivating and planting cereals, sugar beet and potatoes and their interaction with harvesting, timeliness and available labor by linear programming. Journal of Agriculture Engineering Research, v. 23, n. 3, p. 283-300, 1978.

BALASTREIRE, L. A. Máquinas agrícolas. São Paulo: Manole, 1987, 307 p.

BANCHI, A.D. Planejamento da utilização de uma frota de máquinas agrícolas em exploração policultural, determinando a solução de mínimo custo com auxílio de programação linear. Campinas, 1989. 213 p. Dissertação (Mestrado) - Faculdade de Engenharia Agricola, Universidade Estadual de Campinas.

BERNARDES, M. Administração: modelagem matemática aplicada à agricultura. In: FNP CONSULTORIA \& COMÉRCIO. Agrianual 2000. São Paulo, 1999. p.80-81.

BLANCO, H.G.; OLIVEIRA, D.A.; ARAUJO, J.B.M. et al. Observações sobre periodo em que as plantas daninhas competem com a soja (Glycine max (L) Merril). $O$ Biológico, v.39, n. 2, p. 576-580, 1973. 
BROWED, J.A.; PEDIGO, L.P.; OWEN, M.D.K. et al. Soybean yield and pest management as influence by nematodes, herbicides, and defoliating insects. Agronomy Joumal, v. 86, p. 601-608, 1994

BURNSIDE, O.C.; WICKS, G. A.; CARLSON, D.R. Control of rotation in an oat (Avena sativa) - soybean (Glycine max) ecofarming rotation. Weed Science, v. 28, n. 1, p. 46-50, 1980.

BURROWS, W.C.; SIEMENS, J.C. Determination of optimum machinery for cornsoybean farms. Transactions of the ASAE, v. 17, n. 12, p. 1130-1135, 1974.

CÂMARA, G.M.S. Ecofisiologia da cultura da soja. In: SIMPÓSIO SOBRE CULTURA E PRODUTIVIDADE DA SOJA, 1., Piracicaba, 1992. Anais. Piracicaba: FEALQ, 1992. p. 129-142.

CAMARA, G.M.S. Desempenho produtivo dos cultivares de soja IAC-17, IAC-12 e IAC19, semeados em três épocas de semeadura e em cinco densidades de plantas, Piracicaba, 1998a. 164 p. Tese (Livre Docência) - Escola Superior de Agricultura Luiz de Queiroz, Universidade de São Paulo.

CÂMARA, G.M.S. Origem, difusão geográfica e importância da soja In: CÂMARA, G.M.S. (Ed.) Soja: tecnologia da produção. Piracicaba: ESALQ, Depto Agricultura, 1998b. p.1-25.

CÂMARA, M.P.S.; FERREIRA, M.A.S.V.; DIANESSE, J.C. Efeito da aplicação de fungicidas sistêmicos e épocas de plantio sobre a sanidade de sementes de cultivares de soja. Fitopatologia Brasileira, v. 20, n. 2, p. 178-182, 1995.

CAMARGO, M.B.P.; BRUNINI, O.; MIRANDA, M.A.C. Modelo agrometeorológico para a estimativa da produtividade para a cultura da soja no Estado de São Paulo. Bragantia, v. 45, n. 2, p. 279-292, 1986. 
CHANCELLOR, W.J. Selecting the optimum-sized tractor. Transactions of the ASAE, v. 12, n.2, p. $411-414,1969$.

CHANCELLOR, W.J.; CERVILLA, V. Timeliness coefficients for rice and factors affecting their value. Transactions of the ASAE, v. 17, n. 5, p. 841-844, 1974

CHEN, L.H. ; MCCLENDON, R.W. Selection of planting schedule for soybean via simulation. Transactions of the ASAE, v. 27, n. 1, p. 29-32, 35, 1984.

COBER, E.R.; TANNER, J.W.; VOLDENG, H.D. Genetic control of photoperiod response in early-maturing, near-isogenic soybean lines. Crop Science, v. 36, n. 3 , p. 601-605, 1996.

DHINGRA, O.D.; GARCIA, A.; SEDIYAMA, T. Effect of planting time in seed infection by Phomosis sojae in the soybean cultivars. Fitopatologia Brasileira, v. 4, n. 3 , p. $435-440,1979$.

DIEHL, S.R.L. Relatos por estado sobre o comportamento da cultura da soja na safra 1998/99, São Paulo. In: XXI REUNIÃO DE PESQUISA DE SOJA DA REGIÃO CENTRAL DO BRASIL, 21., Dourados, 1999. Ata. Dourados: EMBRAPA, Agropecuária Oeste, 1999. p. 43-46.

DIELEMAN, A.; HAMILL; A.S.; WEISE, S. et al. Empirical model of pigweed (Amaranthus spp.) interference in soybean (Glycine max). Weed Science, v. 43, n. 4, p. $612-618,1995$.

DOURADO-NETO, D. Modelo fitotécnico referente à cultura de milho. 1999. 229 p. Tese (Livre Docência) - Escola Superior de Agricultura "Luiz de Queiroz", Universidade de São Paulo.

DUFFY, P.A. ; TAYLOR, R. Long-term planning on a com-soybean farm: a dynamic programming analysis. Agricultural Systems, v. 42, p. 57-71, 1993. 
EDWARDS, W.; BOEJLHE, M. Machinery selection considering timeliness losses. Transactions of the ASAE, v.23, n.4, p. 810-815, 1980.

ELMORE, R.W. Soybean cultivar response to tillage systems and planting date. Agronomy Journal, v. 82, n. 1, p. 69-73, 1990.

EMPRESA BRASILEIRA DE PESQUISA AGROPECUÁRIA. Centro Nacional de Pesquisa de Soja. Recomendações técnicas para a cultura da soja em regiões de baixas altitudes $\left(<12^{\circ} \mathrm{S}\right)$ Região Central do Brasil 1997/1998. Londrina, 1990. 56 p. (EMPRAPA. CNPSo. Documentos, 41).

EMPRESA BRASILEIRA DE PESQUISA AGROPECUÁRIA. Estimativa de custo de produção de soja, no sistema plantio direto e no convencional, safra 1997/1998, set/98, 1997a. 4p. (EMBRAPA. CNPSo. Comunicado técnico, 33)

EMPRESA BRASILEIRA DE PESQUISA AGROPECUÁRIA. Centro Nacional de Pesquisa de Soja. Recomendações técnicas para a cultura da soja na região Central do Brasil 1997/1998. Londrina, 1997b. 171 p. (EMBRAPA. CNPSo. Documentos, 106)

EMPRESA BRASILEIRA DE PESQUISA AGROPECUÁRIA. Centro Nacional de Pesquisa de Soja. Recomendações técnicas para a cultura da soja na região Central do Brasil 1998/1999. Londrina, 1998. 183 p. (EMBRAPA. CNPSo. Documentos, 107).

ESCOLA SUPERIOR DE AGRICULTURA "LUIZ DE QUEIROZ" . Departamento de Ciências Exatas. Posto metereológico: médias mensais http://unw. ciagri.usp.br/ emdabreu/MEDIAS.TXT (30 Jul. 2000)

FARIAS, J.R.B. Modelos de simulação do desenvolvimento da soja. In: XXI REUNIÃO DE PESQUISA DE SOJA DA REGIÄO CENTRAL DO BRASIL, 21., Dourados, 1999. Ata. Dourados: EMBRAPA, Agropecuária Oeste, 1999. p. 64-67 
FEHR, W.R.; CAVINESS, C.E. Stages of soybean development. Ames: lowa State University of Science and Technology, 1977. $11 p$.

FERREIRA, A.B.H. Novo dicionário da língua portuguesa. São Paulo: Nova Fronteira, 1999. 2569 p.

FLECK, N.G. Interferência da papuã (Braquiaria plantegenia) com a soja e ganho de produtividade obtido através de seu controle. Pesquisa Agropecuária Gaúcha, v. 2, n. 1, p. $63-68,1996$.

FLECK, N.G.; CANDEMIL, C.R.G. Interferência de plantas daninhas na cultura da soja (Glycine max (L) Merril). Ciência Rural, v. 25, n. 1, p. 27-32, 1995.

FLECK, N.G.; CUNHA, M.M.; VARGAS, L. Dose reduzida no controle de papuã na cultura da soja, em função de época de aplicação. Planta Daninha, v. 15, n. 1, p 67 $73,1997$.

FLECK, N.G.; VARGAS, L.; CUNHA, M.M. Controle de plantas daninhas em soja com doses reduzidas de herbicidas. Planta Daninha, v. 13, n. 2, p. 123-128, 1995.

FNP CONSULTORIA \& COMÉRCIO. Agrianual 99. São Paulo, 1998. p.448-483: Soja: redução na lucratividade exige atenção.

FRANCISCO, V.L.F.S.; MARTIN, N.B. A informática na agricultura paulista. Informações Econômicas, v. 29, n. 11, p. 18-25, 1999

GAZZONI, D.L. Efeito da população de percevejos na produtividade, qualidade de sementes e características agronômicas da soja. Pesquisa Agropecuária Brasileira, v. 33, n. 8, p. 1229-1237, 1998.

GLANCEY, J.L.; UPADHYAYA, S.K.;CHANCELLOR, W.J. et al. Prediction of agricultural implement darft using an intrumented analog tillage tool. Soil and Tillage Research, v. 37, n.1, p. 47-65, 1995. 
GRIMM, S.S.; JONES, J. W.; BOOTE, K. J. et al. Parameter estimation for flowering date of soybean cultivars. Crop Science, v. 33, n. 1, p. 137-144, 1993.

HARRIGAN, T.M; ROTZ, C.A. Draft of major tillage and seedind equipament. St. Joseph, 1994. 21p. (ASAE. Paper, 94-1533)

HOOGENBOOM, G.; JONES, J.W.; BOOTE, K.J. Modeling growth, development, and yield of grain legumes using SOYGRO, PNUTGRO and BEANGRO: a review. Transactions of the ASAE, $v$ 35, n 6, p. 2043-2056, 1992.

HUNT, D. Farm power machinery. 6.ed. lowa: lowa State University Press, 1974. $323 \mathrm{p}$.

JANNOT, Ph.; CAIROL, D. Linear programming as an aid to decision making for investments farm equipment for arable farms. Journal of Agricultural Enginnnering Research, v. 59, n. 2, p. 173-179, 1996.

LAL, H.; JONES, J. W.; PEART, R. M. et al. FARMASYS - a whole-farm machinery mangement decision support system. Agricultural Systems, v.38, p.257-273, 1992.

LAL, H.; PEART, R.M.; JONES, J.W. et al. An intelligent information manager for knowledge-based systems. Applied Engineering in Agriculture, v.6, n.4, p.525$531,1990$.

LAL, H.; PEART, R.M.; JONES, J. W. et al. An objective-oriented field operations simulator in PROLOG. Transactions of the ASAE, v. 34, n. 3, p. 1031-1035, 1991.

LINDQUIST, J.L.; MAXWELL, B.D.; BUHLER, D.D. et al. Modeling the population dynamics and economics on velvetleaf (Abutilon theophrasti) control in a corn (Zea mays) - soybean (Glycine max) rotation. Weed Science, v. 43, n. 2, p. 269-275, 1995. 
MARCOS FILHO, J.; NOVEMBRE, A.D.L.C. Características agronômicas e fenologia da soja (Glycina $\max$ (L.) Merril) sob influência da época de semeadura: relatório técnico apresentado ao Conselho de Desenvolvimento Científico e Tecnológico (CNPq). Piracicaba: ESALQ, 1990. 57 p.

MARCHIORI, L.F.S. Desempenho vegetativo e produtivo de três cultivares de soja em cinco densidades populacionais nas épocas normal e safrinha. Piracicaba, 1998. 55p. Dissertação (Mestrado) - Escola Superior de Agricultura "Luiz de Queiroz", Universidade de São Paulo.

MAROCHI, A.l. Avaliação do periodo ideal entre aplicação e ocorrência de chuva, para herbicidas e ocorrência de chuva, para herbicidas de ação sistêmica, utilizados em dessecação no plantio direto. Zapp: O desafio do novo. São Paulo: Zeneca Agricola, 1996. 194 p.

MASCARENHAS, H.A.A.; TANAKA, R. T. Soja. In: RAIJ, B van.; CANTARELLA, H.; QUAGGIO, J. A. et al. (Ed.) Recomendações de adubação e calagem para o Estado de São Paulo. 2.ed. Campinas: Instituto Agronônico, 1996. p. 202-203. (IAC. Boletim Técnico, 100).

MASCARENHAS, H.A.A.; TANAKA, R.T.; COSTA, A.A. et al. Efeito residual de leguminosas sobre rendimento físico e econômico da cana-planta. Campinas: IAC, 1994. 15 p. (IAC. Boletim Cientifico, 32)

MCCLEDON, R. W.; WESTZSTEIN, M. E.; EDWARDS, D. W. et al. Risk efficiency of machinery selection for double cropping via simulation. Transactions of the ASAE, v. 30, n. 5, p. $1259-1265,1987$.

MELLO, L. M. Efeitos de diferentes sistemas de preparo de solo na cultura da sja (Glycine max (L.) Merril) e sobre algumas propriedades de um Latossolo Vermelho de Cerrado. Botucatu, 1988. 129 p. Tese (Doutorado) - Faculdade de Ciências Agrárias, Universidade Estadual Paulista "Júlio de Mesquita Filho". 
MIALHE, L. G. Manual de mecanização agricola. São Paulo: Ceres, 1974. 301p.

MILAN, M. Improving operacional management of harvest, transport and mechanization for sugar-cane in Brazil. Silsoe, 1992. 226p. Ph.D (Thesis) - Silsoe College, Crainfield Institute of technology.

MORRISON, A. Modeling the growth and water use of plants. In: BRAZILIAN AGROMETEOROLOGICAL CONGRESS, 7. CURSE OF CLIMATIC SIMULATION. Viçosa, Brazil, 15 p. 1991

NAKANO, O; SILVEIRA NETO, S.; ZUCCHI, R. Entomologia econômica. São Paulo: Livroceres, 1981. $314 \mathrm{p}$.

OSLER, R. D. ; CARTER J. L. Effect of planting date on chemical composition and growth characteristics of soybean. Agronomy Journal, v. 16, n. 6, p. 260-270, 1954.

OUATTARA, S. ; WEAVER, D. B. Effect of growth habit on yield components of lateplanted soybean. Crop Science, v. 35, n. 2, p. 411-415, 1995.

OZKAN, H. E. ; HOLMES R. G. Determining machinery timeliness cost in corn planting using DRAINMOD. Transactions of the ASAE, v. 33, n. 3, p 718-724, 1990.

PARKER, M. B.; MARCHANT, W. H.; MULLINIX Jr, B. J. Date planting and row spacing effects on four soybean cultivars. Agronomy Journal, v. 73, n. 5, p. 759$762,1981$.

PARMAR, R. S.; MCCLEDON R. W.; POTTER, W. D. Farm machinery selection using simulation and genetic algorithms. Transactions of the ASAE, v. 39, n. 5, p. 19051909, 1996. 
PARMAR, R. S.; MCCLEDON, R. W.; WILLIAMS, E. J. A computer simulation model for peanut machinery management. Applied Engineering in Agriculture, v. 10 , n. 4 , p. $455-461,1994$.

PARSONS, S. D.; SMITH, T. W.; KRUTZ, G. W. Machinery downtime costs. Transactions of the ASAE, v. 23, n. 2, p. 541-544, 1981.

PHILIPS, P. R.; CALLAGAN, J.R. Cereal harvesting - a mathematical model. Journal of Agricultural Engineering Research, v. 19, n. 4, p. 415-433, 1974.

PRASAD, J. A comparison between a rotavator and conventional tillage equipament for wheat-soybean rotations on a vertisol Central India. Soil and Tillage Research, v. 37, n. $2 / 3$, p. 191-199, 1996.

QUEIROZ, E. F. Efeito de época de plantio e população sobre o rendimento e outras características agronômicas de quatro cultivares de soja (Glycine max (L.) Merril). Porto Alegre, 1975. 108 p. Dissertação (Mestrado) - Faculdade de Agronomia, Universidade Federal do Rio Grande do Sul.

QUEIROZ, E. F. Quantificação do efeito da oferta hídrica sobre a resposta da soja (Glycine max (L.) Merril) a época de plantio na região Norte do Paraná. Piracicaba, 1988. 312p. Tese (Doutorado) - Escola Superior de Agricultura "Luiz de Queiroz, Universidade de São Paulo.

RENGEL, Z. Mechanistic simulation models of nutrient uptake: a review. Plant and Soil, v. 152, p. 161-173, 1993.

REZENDE, P. M; VIEIRA, M. G. G. C; VIERA NETO, J. C. et al. Influência da aplicação de herbicidas no rendimento de grãos, nodulação e qualidade fisiológica das sementes de soja. Pesquisa Agropecuária Brasileira, v. 20, n. 1, p. 25-30, 1985 
SANTOS, V. L. M.; SILVA, R. F.; CARDOSO, A. A. et al. Avaliação da produtividade e da qualidade das sementes de genótipos de soja (Glycine max (L.) Merril) colhidas na maturação fisiológica e trinta dias após o ponto de colheita. Revista Brasileira de Sementes, v.18, n.1, p. 50-56, 1996.

SAS INSTITUTE. User's guide: statistis; release 6.03. Cary, 1988. 1028 p.

SCHEWEIZER, E. E.; WESTRA, P.; LYBECKER, D. W. Controlling weeds in com (Zea Mays) rows with an in-row cultivator versus decisions made by a computer model. Weed Science, v. 42, n. 4, p. 593-600, 1992.

SEDIYAMA, C. S. Influência do retardamento da colheita da soja sobre a deiscência das vagens, qualidade e poder germinativo das sementes. Viçosa, 1972. 68 p. Dissertação (Mestrado) - Universidade Federal de Viçosa.

SENTELHAS. P. C.; PEREIRA, A. P.; ANGELOCCI, L. R. Metereologia agrícola. Piracicaba: ESALQ, 1998. 131 p.

SILVA, M. A. V. Microaulas - Metereologia (software). Recife: UFRPE, 1992.

SOUZA, L. C. F.; CRUZ, J. C.; RAMALHO, M. A. P. et al. Efeito da antecedência da gradagem ao plantio do milho no controle de plantas daninhas. Pesquisa Agropecuária Brasileira, v. 31, n. 11, p. 789-793, 1996.

STOLF, R. Grades e seus tratores: exemplos práticos de seleção. Álcool e Açúcar, v. 2, n. 29, p. 123-128, 1986.

STONNER, R. K.; MILAN, M.; RIPOLI, T. C. C. Gerenciamento de sistemas agrícolas em unidades sucroalcooleiras através de programação linear. Stab. Açúcar, Álcool e Subprodutos, v. 11, n. 5, p. 16-20, 1992. 
SWEENEY, D. W.; GRANADE, G. V.; BURTON Jr, R. Early and traditionally maturing soybean varieties grown in two planting systems. Joumal of Productive Agriculture, v. 8, n. 3, p. 373-379, 1995.

SWINTON, S. M. ; KING, R. P. A bioeconomic model for weed management in corn and soybean. Agricultural Systems, v. 44, p. 313-335, 1994.

TSAI, Y. J.; JONES J. W.; MISHOE, J.W. Optimizing multiple cropping systems: a systems approach. Transactions of the ASAE, v. 30, n. 6, p. 1554-1561, 1987.

WEISS, M. G.; WEBER, C. R.; WILLIANS, L. F. et al. Variability of agronomic and seed compositional characters in soybean as influenced by variaty and time of planting. Washington: USDA, 1950. 39 p. (USDA. Techinical Bulletin, 1017)

WHITE, M. E. J. Machinery selection and budgenting using Lotus 1-2-3. Silsoe College, 1986. 86 p. Dissertation (M.Sc.) Cranfield Institute of Technology.

WITNEY, B D. Choosing \& using farm machines. Edinburgh: Land Technology, 1988. $412 \mathrm{p}$.

WITNEY, B. D.; ERADAT, O. K. The basis of tractor power selection on arable farms. Joumal of Engineering Research, v. 27, n. 2, p. 513-527

ZOZ, F. Optimum width and speed for least cost tillage. Transactions of the ASAE, v. 17, n. 5, p. $845-850,1974$.

No fim tudo dá certo. Senão deu certo é porque não chegou ao fim. (Fernando Sabino) 